\title{
Fine Tuning of Crystal Packing and Charge Transport Properties of BDOPV Derivatives through Fluorine Substitution
}

Jin-Hu Dou, ${ }^{\dagger}{ }^{\S}$ Yu-Qing Zheng, ${ }^{\dagger} \S$ Ze-Fan Yao, ${ }^{\dagger}$ Zhi-Ao Yu, ${ }^{\dagger}{ }^{\text {Ting Lei }}{ }^{\dagger}$ Xingxing Shen, ${ }^{\ddagger} \mathrm{Xu}-$ Yi Luo, ${ }^{\dagger}$ Junliang Sun ${ }^{\dagger}$ Shi-Ding Zhang, ${ }^{\dagger}$ Yi-Fan Ding, ${ }^{\dagger}$ Guangchao Han, ${ }^{\ddagger}$ Yuanping Yi, ${ }^{*}+$ Jie-Yu Wang, ${ }^{*} \dagger$ and Jian Pei* ${ }^{*} \dagger$

+ Beijing National Laboratory for Molecular Sciences (BNLMS), the Key Laboratory of Bioorganic Chemistry and Molecular Engineering of Ministry of Education, Center of Soft Matter Science and Engineering, College of Chemistry and Molecular Engineering, Peking University, Beijng 100871, China.

fKey Laboratory of Organic Solids, Institute of Chemistry, Chinese Academy of Sciences, Beijing, 100190, China.

*Tel: +86-10-62758145, Fax: +86-10-62751708,E-mail: jianpei@pku.edu.cn

\$These authors contribute equally

$$
\text { jianpei@pku.edu.cn (J.P.) }
$$

\section{Table of Contents}

1. General procedures and experimental details

2. X-ray crystallographic analysis

3. Device fabrication and characterization

4. Computational methods

5. Figures S1-18 \& Tables S1-3

6. Synthetic procedures and characterization

7. ${ }^{1} \mathrm{H}$ and ${ }^{13} \mathrm{C}$ NMR spectra of new compounds 


\section{General procedures and experimental details}

All commercially available chemicals were used without further purification unless otherwise noted. CYTOP was purchased from Asahi Glass Co., Ltd. including the polymer solution CTL809M and the solvent CT-solv180. All air and water sensitive reactions were performed under nitrogen atmosphere. Column chromatography was performed with silica gel. Analytical thin-layer chromatography (TLC) was performed on $0.2 \mathrm{~mm}$ silica gel-coated glass sheets with F254 indicator. All yields given referred to isolated yields. ${ }^{1} \mathrm{H}$ and ${ }^{13} \mathrm{C} \mathrm{NMR}$ spectra were recorded on Bruker AVANCE III spectrometers $400 \mathrm{MHz}$ or Bruker AVANCE III spectrometers $500 \mathrm{MHz}$. All chemical shifts were reported in parts per million (ppm). TMS (0 ppm) was the reference for ${ }^{1} \mathrm{H}$ NMR chemical shifts, and $\mathrm{CDCl}_{3}(77.00 \mathrm{ppm})$ and $\mathrm{CD}_{2} \mathrm{Cl}_{2}$ $(53.84 \mathrm{ppm})$ were the reference for ${ }^{13} \mathrm{C}$ NMR chemical shifts. Mass spectra were recorded on a Bruker Apex IV Fourier Transform Ion Cyclotron Resonance Mass Spectrometer. Elemental analyses were performed on a German Vario EL III elemental analyzer. Differential scanning calorimetry (DSC) analyses were performed using a METTLER TOLEDO Instrument DSC822 calorimeter. Thermal gravity analyses (TGA) were performed on a TA Instrument Q600 analyzer under $\mathrm{N}_{2}\left(10{ }^{\circ} \mathrm{C} \min ^{-1}\right)$. Absorption spectra were recorded on PerkinElmer Lambda 750 UV-vis spectrometer. Cyclic Voltammetry (CV) was performed on BASi Epsilon workstation and measurements were recorded in acetonitrile with $0.1 \mathrm{M} \mathrm{n}$-Bu4NPF 6 as supporting electrolyte, glassy carbon electrode as working electrode and platinum wire as counter electrode. All potentials were represented versus $\mathrm{Ag} / \mathrm{AgCl}$ (saturated) as reference electrode (scan rate: $50 \mathrm{mV} \mathrm{s}^{-1}$ ) and the $\mathrm{Fc} / \mathrm{Fc}^{+}$redox couple was used as an external standard. Scanning electron microscopy (SEM) images were obtained by a cold field emission scanning electron microscope (FESEM, Hitachi S-4800) operated at an accelerating voltage of $1.0 \mathrm{kV}$. Transmission electron microscopy (TEM) images were obtained by a transmission electron microscope (Tecnai G2 F20 U-TWIN) operated at accelerating voltage of $120 \mathrm{kV}$ and selected area electron diffraction (SAED) was taken at an accelerating voltage of $120 \mathrm{kV}$. The 
d-spacing was calibrated using a $\mathrm{TiCl}$ standard. All the samples were prepared by directly drop-casting the micro-ribbon suspensions on a copper grid covered with a thin carbon support film. Optical microscopy (OM) images were obtained by Leica S6 E stereoscopic microscope. Atomic force microscopy studies were performed with a Nanoscope IIIa microscope (Extended Multimode) at tapping mode under ambient conditions using silicon nitride cantilever (Budget Sensors Tap300Al) with a resonant frequency around $300 \mathrm{kHz}$. 


\section{X-ray crystallographic analysis}

Single crystals data collections were performed at $180 \mathrm{~K}$ for BDOPV, $o-\mathrm{F}_{2}-\mathrm{BDOPV}$ and $p-\mathrm{F}_{2}-$ BDOPV on a SuperNova diffractometer, using graphite-monochromated Mo Ka radiation $\left(\lambda=0.71073 \AA\right.$ ). Data of $\mathrm{F}_{4}$-BDOPV and $\mathrm{F}_{6}$-BDOPV was performed at $180 \mathrm{~K}$ on a SuperNova diffractometer, using graphite-monochromated $\mathrm{Cu} \mathrm{K} \alpha$ radiation $(\lambda=1.54184 \AA)$. Using Olex2, these structures were solved with the ShelXS and refined with the ShelXL97 refinement package using Least Squares minimization. Refinement was performed on $F^{2}$ anisotropically for all the non-hydrogen atoms by the full-matrix least-squares method. The hydrogen atoms were placed at the calculated positions and were included in the structure calculation without further refinement of the parameters. Crystallographic data have been deposited with the Cambridge Crystallographic Data Centre as supplementary publication numbers. These data can be obtained free of charge from the Cambridge Crystallographic Data Centre via www.ccdc.cam.ac.uk/data_request/cif. See Supplementary Table S1\& Table S2 and Supplementary Fig. S8 \& Fig. S9 for the crystal data details of five BDOPV derivatives. 


\section{Device fabrication and characterization}

For SC-OFET device, bottom-gate/top-contact (BG/TC) device configuration is adopted using $\mathrm{n}^{++}-\mathrm{Si} / \mathrm{SiO}_{2}(300 \mathrm{~nm})$ as substrates. A Cytop solution (CTL809M:CT-solv180 = 1:1) was spincoated onto the $\mathrm{Si} / \mathrm{SiO}_{2}$ substrate at $2000 \mathrm{rpm}$ for $60 \mathrm{~s}$ and then was baked at $120{ }^{\circ} \mathrm{C}$ for $1 \mathrm{~h}$ in a glovebox resulting in a dielectric layer of $230 \mathrm{~nm}$ thickness. Single crystals were spincoated from solutions onto it. $\mathrm{Au}(\sim 30 \mathrm{~nm})$ as source/drain electrodes is deposited under vacuum $\left(\sim 4 \times 10^{-4} \mathrm{~Pa}\right)$ via the plastic wire shadow mask method. All the fabrication and test processes are conducted under ambient conditions unless otherwise noted.

The evaluations of the FETs were carried out in atmosphere $\left(\mathrm{R}_{H}=50-60 \%\right)$ on a probe stage using a Keithley 4200 SCS as parameter analyzer. The carrier mobility, $\mu$, was calculated from the data in the saturated regime according to the equation $I_{\mathrm{SD}}=(W / 2 L) C_{\mathrm{i}} \mu\left(V_{\mathrm{G}}-V_{\mathrm{T}}\right)^{2}$, where $I_{\mathrm{SD}}$ is the drain current in the saturated regime. $W$ and $L$ are the semiconductor channel width and length, respectively. For SC-OFET devices, $W$ and $L$ represent the width of the crystal and channel length, which are obtained from SEM test of the corresponding devices. $C_{\mathrm{i}}(4.5 \mathrm{nF}$ for Cytop $(230 \mathrm{~nm}, 7.7 \mathrm{nF}) / \mathrm{SiO}_{2}$ layer $\left.(300 \mathrm{~nm}, 11 \mathrm{nF})\right)$ is the capacitance per unit area of the gate dielectric layer. $V_{\mathrm{G}}$ and $V_{\mathrm{T}}$ are the gate voltage and threshold voltage. $V_{\mathrm{G}}-V_{\mathrm{T}}$ of the device was determined from the relationship between the square root of $I_{\mathrm{SD}}$ and $V_{\mathrm{G}}$ at the saturated regime. 


\section{Computational methods}

The geometry optimizations for the ground and charged states were performed by density functional theory (DFT) at the B3LYP/6-31G** level. The electron reorganization energies were calculated from the adiabatic potential surfaces of the neutral and negatively-charged states. The transfer integrals for electrons for the molecular pairs extracted from the experimental crystal structures were evaluated at the DFT-B3LYP/6-31G** level using a fragment orbital approach in combination with a basis set orthogonalization procedure. ${ }^{1}$ The electrostatic potential (ESP) maps of the molecules and dimers for the BDOPV derivatives were calculated with an isovalue of 0.0004 from the total electron density obtained by DFT at the B3LYP/6-31G** level. All the DFT calculations were carried out with the Gaussian 09 package. $^{2}$

[1] Valeev, E. F.; Coropceanu, V.; da Silva Filho, D. A.; Salman, S.; Brédas, J.-L. J. Am. Chem. Soc. 2006, 128, 9882.

[2] Frisch, M. J.; Trucks, G. W.; Schlegel, H. B.; Scuseria, G. E.; Robb, M. A.; Cheeseman, J. R.; Scalmani, G.; Barone, V.; Mennucci, B.; Petersson, G. A.; Nakatsuji, H.; Caricato, M.; Li, X.; Hratchian, H. P.; Izmaylov, A. F.; Bloino, J.; Zheng, G.; Sonnenberg, J. L.; Hada, M.; Ehara, M.; Toyota, K.; Fukuda, R.; Hasegawa, J.; Ishida, M.; Nakajima, T.; Honda, Y.; Kitao, O.; Nakai, H.; Vreven, T.; Montgomery, J. A., Jr.; Peralta, J. E.; Ogliaro, F.; Bearpark, M.; Heyd, J. J.; Brothers, E.; Kudin, K. N.; Staroverov, V. N.; Keith, T.; Kobayashi, R.; Normand, J.; Raghavachari, K.; Rendell, A.; Burant, J. C.; Iyengar, S. S.; Tomasi, J.; Cossi, M.; Rega, N.; Millam, J. M.; Klene, M.; Knox, J. E.; Cross, J. B.; Bakken, V.; Adamo, C.; Jaramillo, J.; Gomperts, R.; Stratmann, R. E.; Yazyev, O.; Austin, A. J.; Cammi, R.; Pomelli, C.; Ochterski, J. W.; Martin, R. L.; Morokuma, K.; Zakrzewski, V. G.; Voth, G. A.; Salvador, P.; Dannenberg, J. J.; Dapprich, S.; Daniels, A. D.; Farkas, O.; Foresman, J. B.; Ortiz, J. V.; Cioslowski, J.; Fox, D. J.; Gaussian 09, Revision D.01, Gaussian, Inc.: Wallingford CT, USA, 2013. 


\section{Figures S1-S18 \& Tables S1-3}

Herringbone

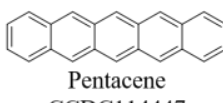

Pentacene

CCDC114447

FET mobility: $15-40 \mathrm{~cm}^{2} \mathrm{~V}^{-1} \mathrm{~s}^{-1}$

Jurchescuet, O. D. et al. Adv. Mater. 2007, 19, 688

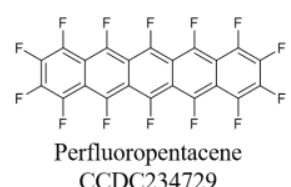

FET mobility: $0.11 \mathrm{~cm}^{2} \mathrm{~V}^{-1} \mathrm{~s}^{-1}$

Sakamoto, Y. et al. J. Am. Chem. Soc. 2004, 126, 8138 .

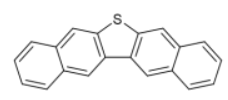

DNT-V

CCDC886144

FET mobility: $1.5 \mathrm{~cm}^{2} \mathrm{~V}^{-1} \mathrm{~s}^{-1}$

Okamoto, T. et al. Adv. Mater. 2013, 25, 6392.

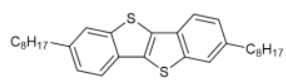

C8-BTBT

CCDC679293

FET mobility: $2.9 \mathrm{~cm}^{2} \mathrm{~V}^{-1} \mathrm{~s}^{-1}$

Izawa, T. et al. Adv. Mater. 2008, 20, 3388.

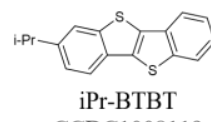

1Pr-BTBT
CCDC1008119

FET mobility: $0.08 \mathrm{~cm}^{2} \mathrm{~V}^{-1} \mathrm{~s}^{-1}$

Schweicher, G. et al. Adv. Mater. 2015, 27, 3066.

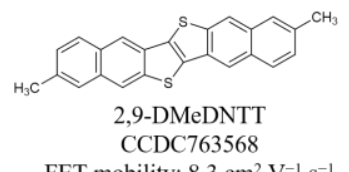

FET mobility: $8.3 \mathrm{~cm}^{2} \mathrm{~V}^{-1} \mathrm{~s}^{-1}$

Haas, S. et al. Appl. Phys. Lett. 2009, 95, 022111.

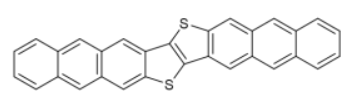$$
\text { DAT1 } 839976
$$

FET mobility: $4.8 \mathrm{~cm}^{2} \mathrm{~V}^{-1} \mathrm{~s}^{-1}$

Niimi, K. et al. J. Am. Chem. Soc. 2011, 133, 8732.

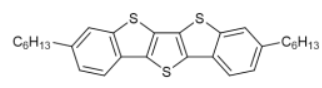

C6-DBTDT

CCDC 830987

FET mobility: $1.8 \mathrm{~cm}^{2} \mathrm{~V}^{-1} \mathrm{~s}^{-1}$

Li, R. et al. Adv. Mater. 2009, 21, 4492 .
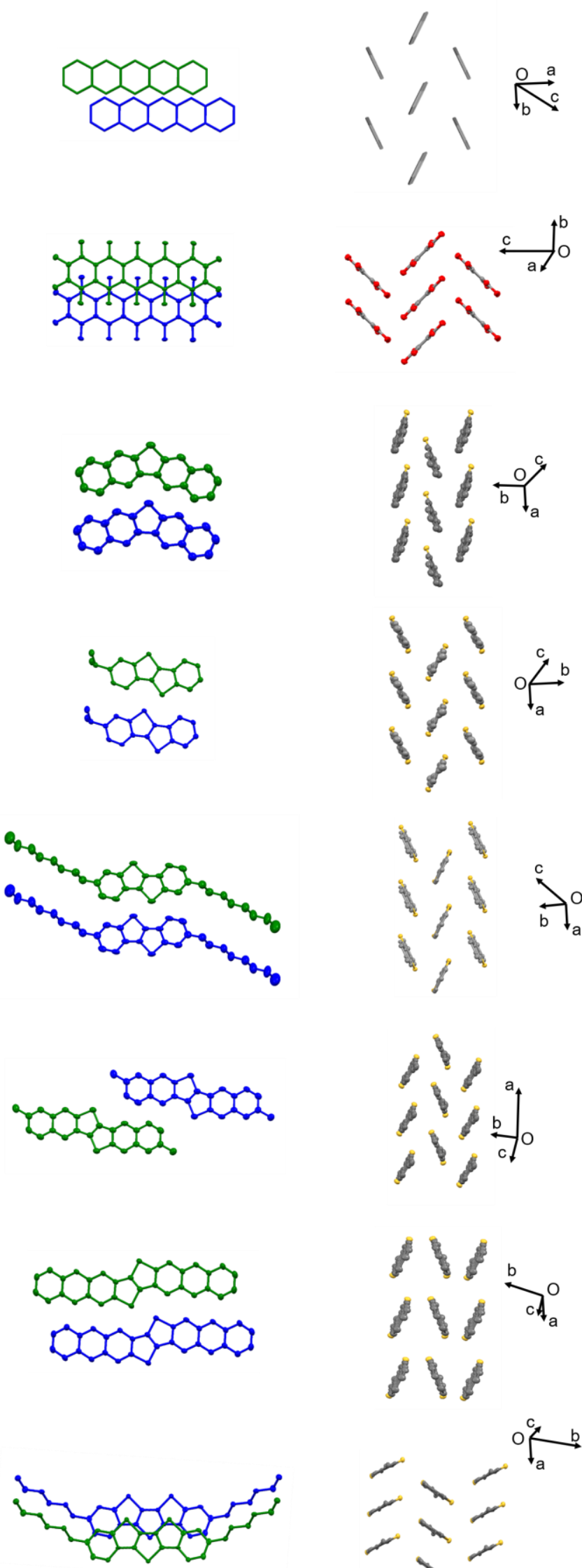

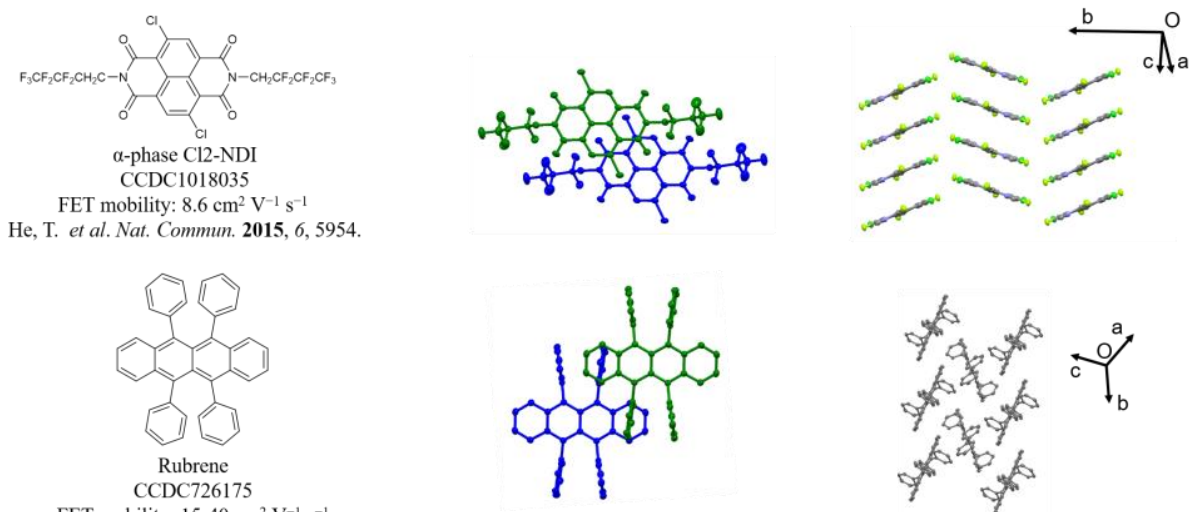

FET mobility: 15-40 $\mathrm{cm}^{2} \mathrm{~V}^{-1} \mathrm{~s}^{-1}$

Yamagishi, M. et al. Appl. Phys. Lett. 2009, 90, 182117.
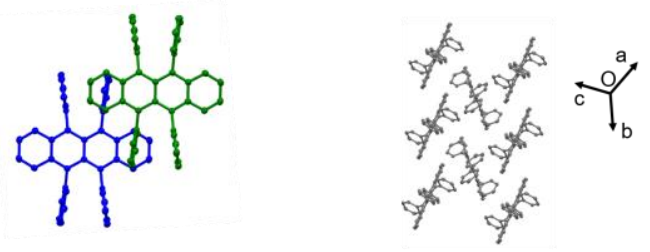

1D slipped-stack
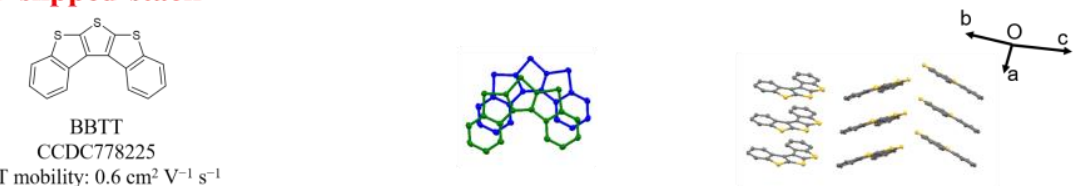

Li, R. et al J.Mate: Chem 2010, 20,6014.
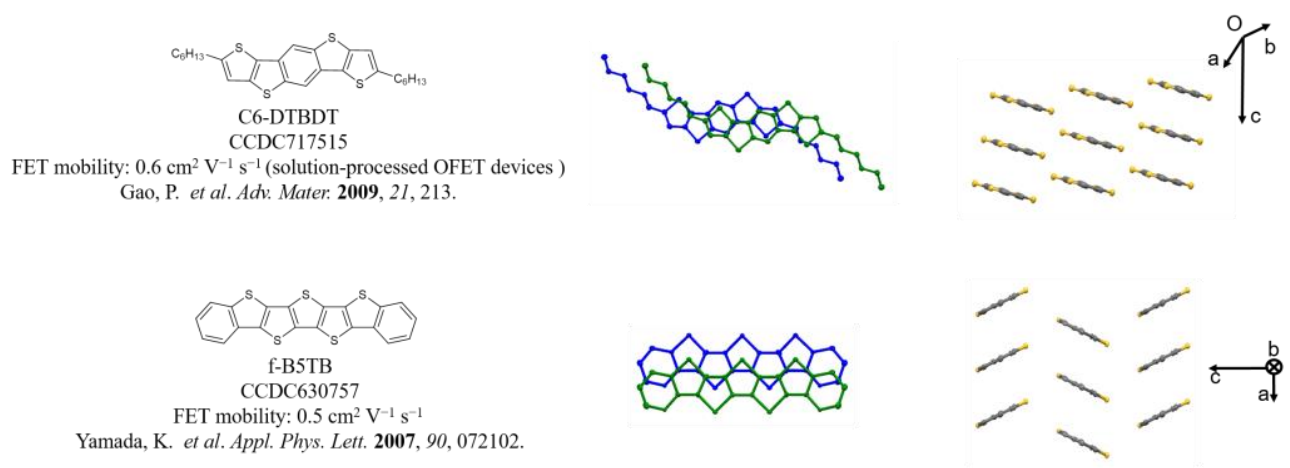

Yamada, K. et al. Appl. Phys. Lett. 2007, 90, 072102.
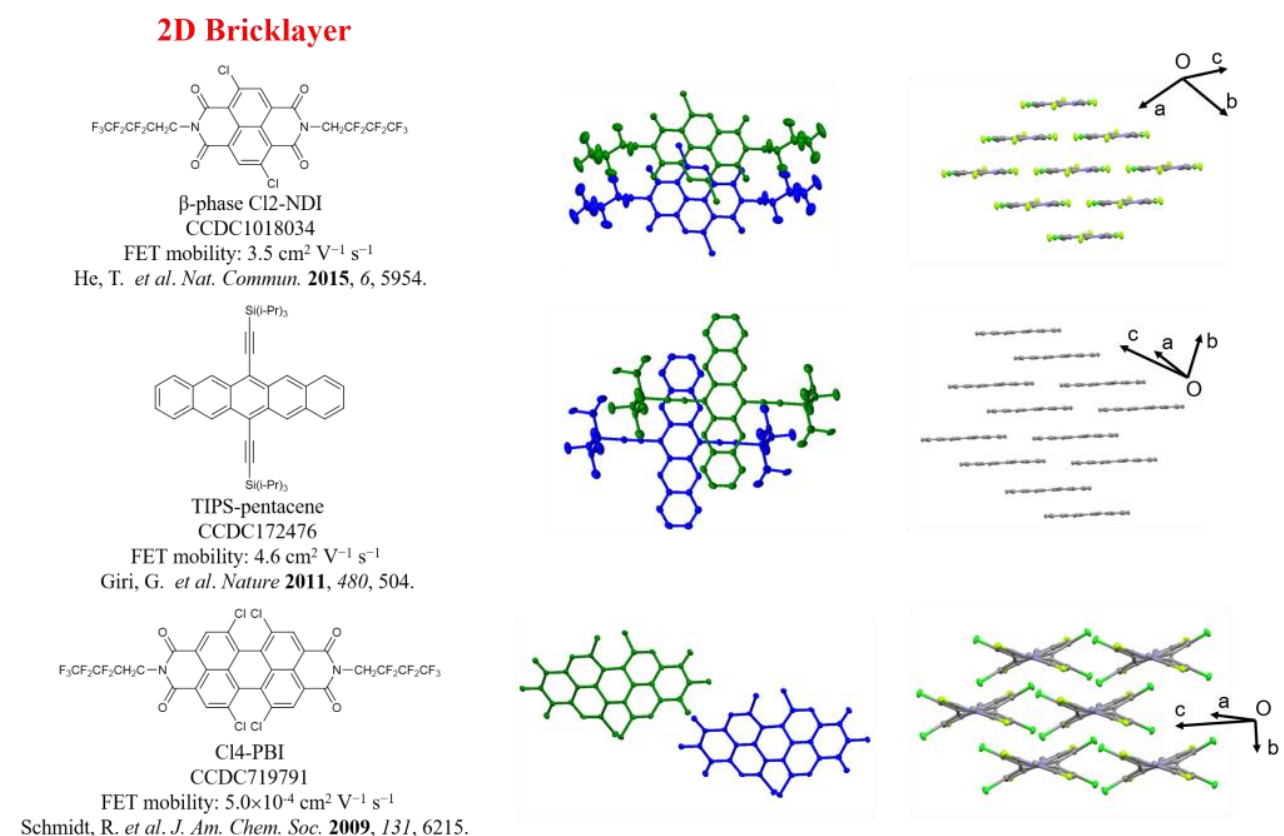

Figure S1. Molecular structure and crystal packing structures of eighteen representative high mobility small molecular (Note: two polymorphs of $\mathrm{Cl}_{2}$-NDI are considered). The red, green, blue, and grey coloured atoms represent $\mathrm{O}, \mathrm{F}, \mathrm{N}$, and $\mathrm{C}$ respectively. Molecular packing structures are taken from the published crystal data of references as mentioned. 

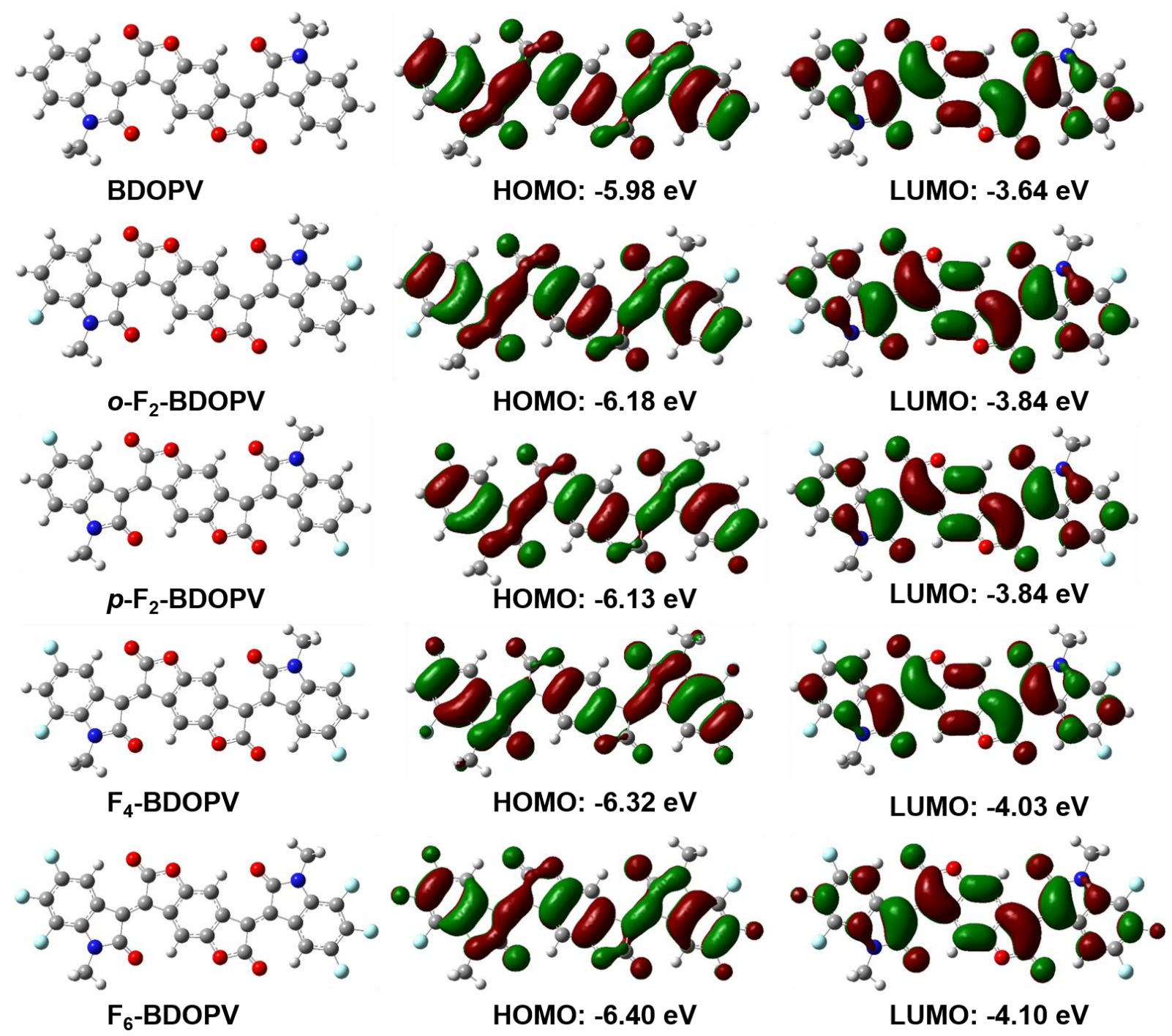

Figure S2. Molecular geometry and frontier molecular orbitals of five BDOPV-Me derivatives calculated at the DFT-B3LYP/6-311G(d,p) level. 


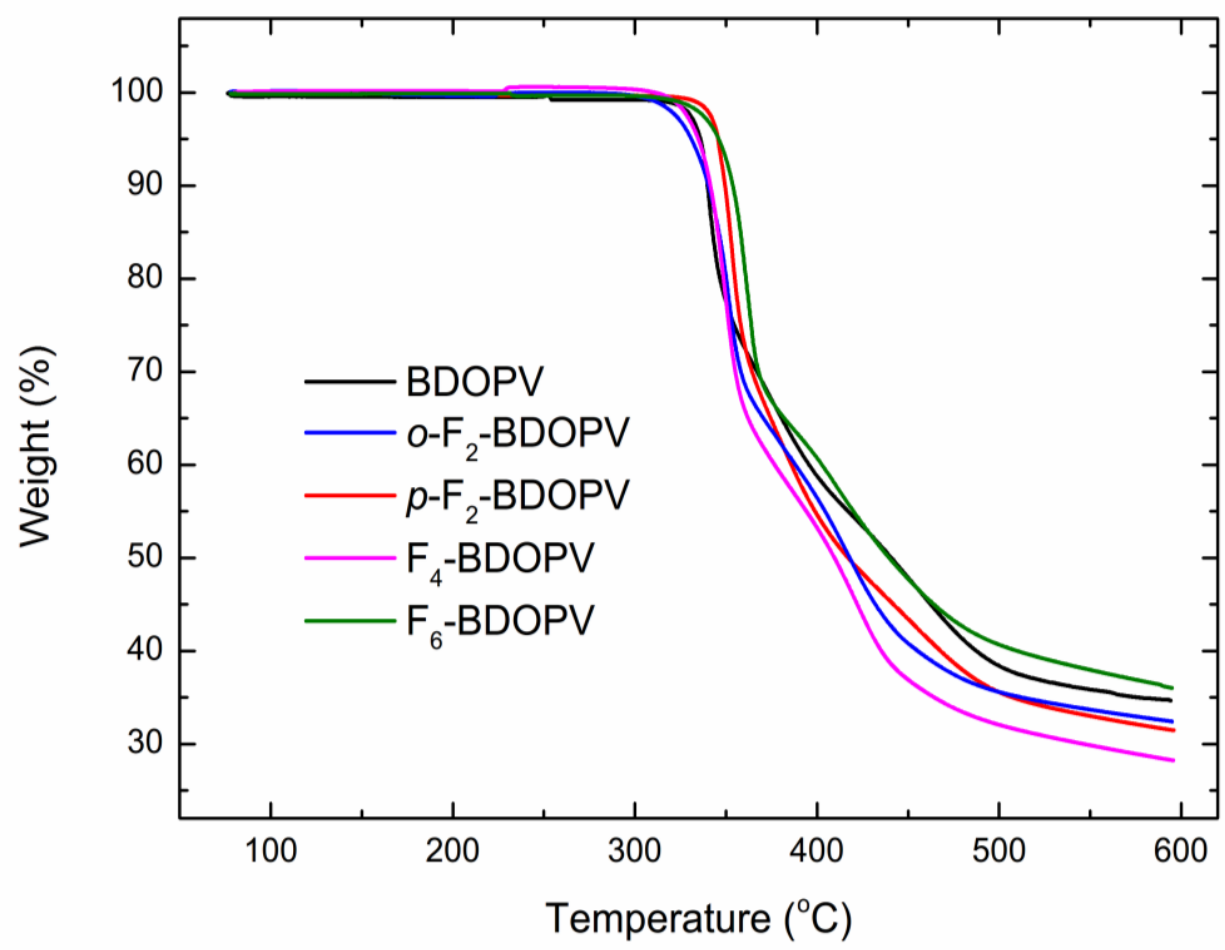

Figure S3. Thermal gravity analysis (TGA) of five BDOPV derivatives.

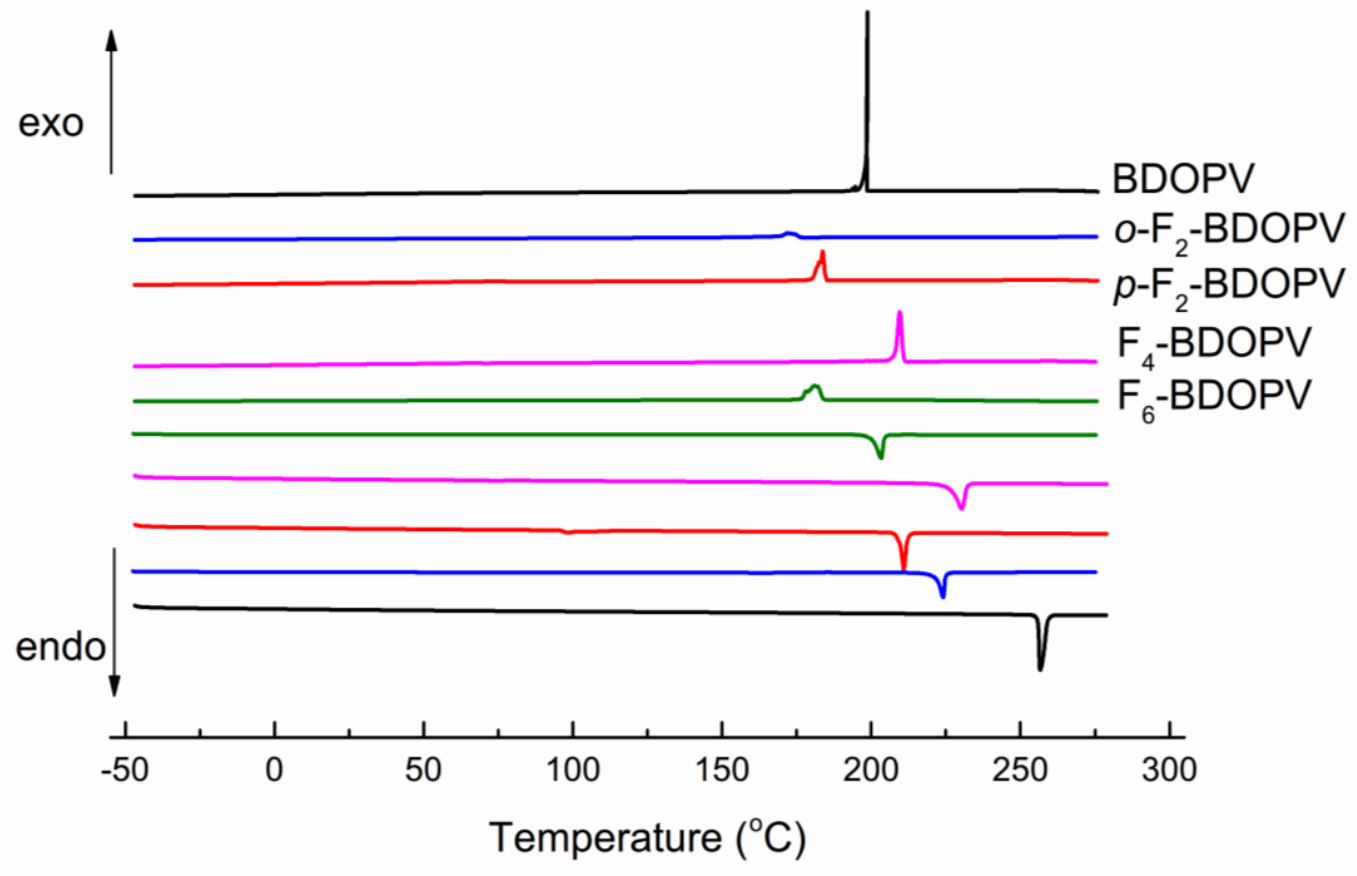

Figure S4. DSC thermograms of five BDOPV derivatives in nitrogen at a ramp rate of $10{ }^{\circ} \mathrm{C}$ $\mathrm{min}^{-1}$. The lower trace is from the heating cycle and upper trace from the cooling cycle. 

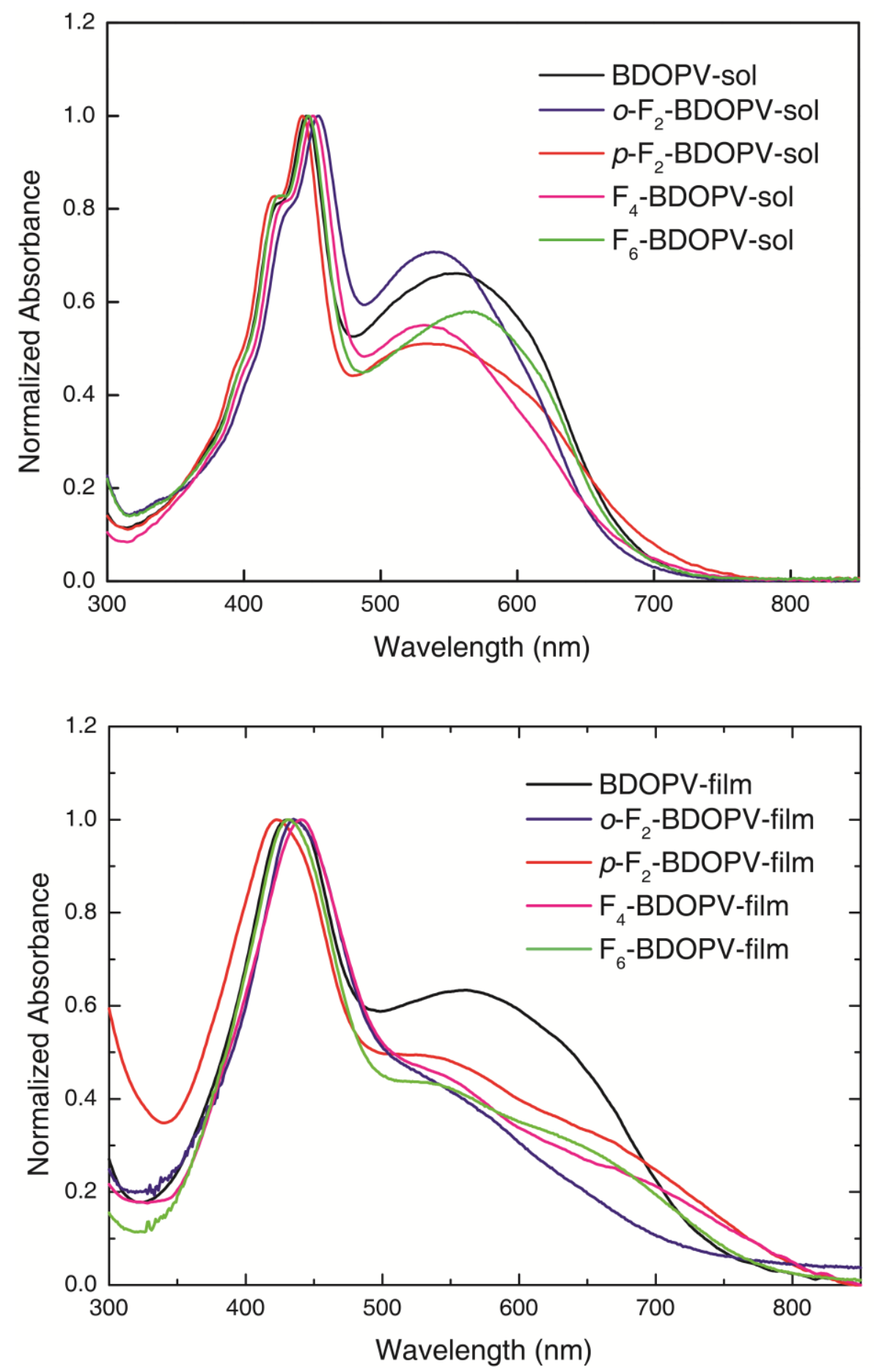

Figure S5. Normalized absorption spectra of chloroform solutions (up) $\left(1 \times 10^{-5} \mathrm{M}\right)$ and their pristine films (down) spin-coated from chloroform solution $(1 \mathrm{mg} / \mathrm{mL})$ of five BDOPV derivatives respectively. 

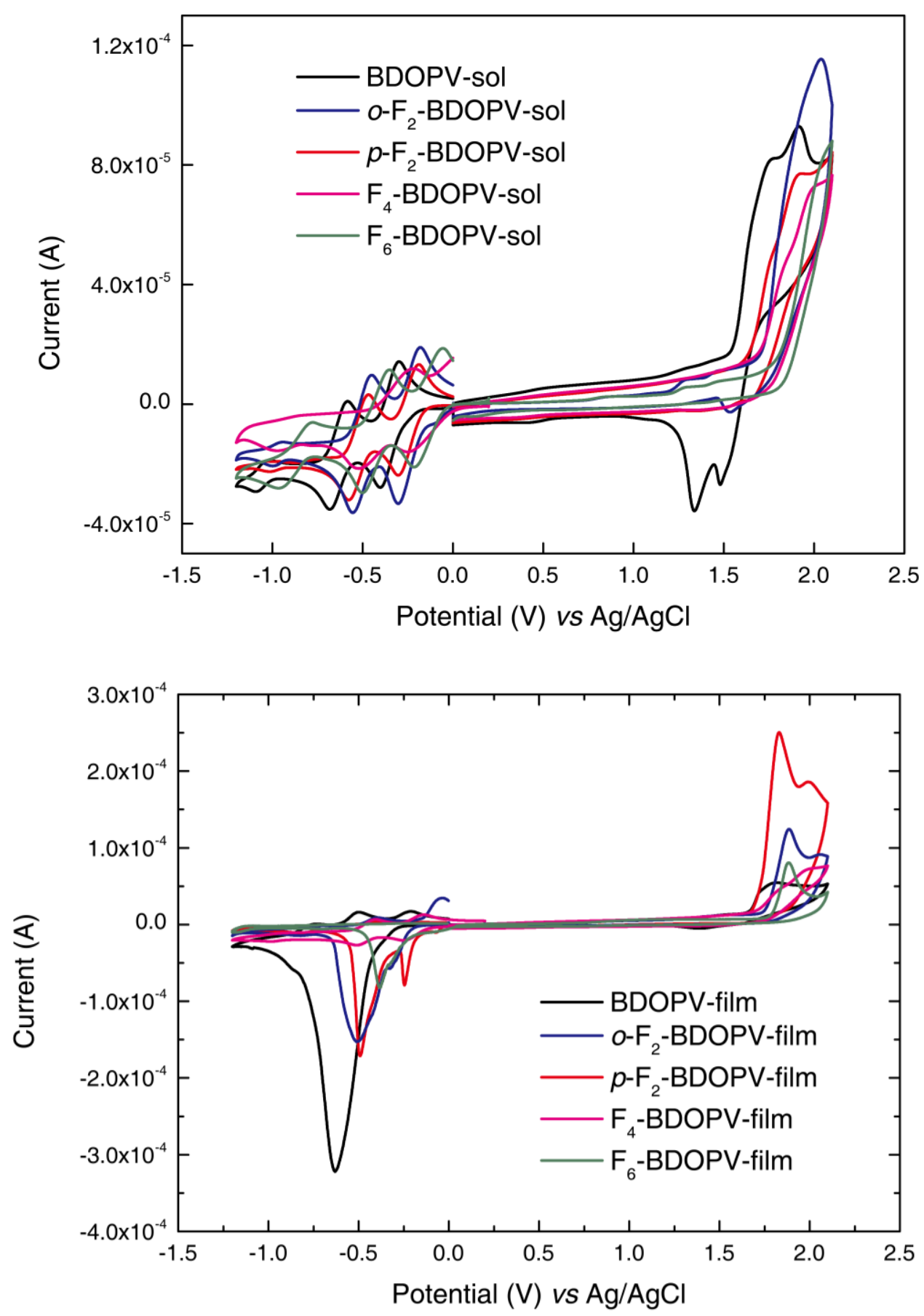

Figure S6. $\mathrm{CV}$ curves of five BDOPV derivatives tested in $n-\mathrm{Bu}_{4} \mathrm{NPF}_{6} / \mathrm{CH}_{2} \mathrm{Cl}_{2}$ solution (scan rate: $50 \mathrm{mV} \mathrm{s}^{-1}$ ) (up) and in pristine film spin-coated from chloroform solution $(1 \mathrm{mg} / \mathrm{mL})$ (scan rate: $50 \mathrm{mV} \mathrm{s}^{-1}$ ), tested in $n$-Bu4NPF $/$ Acetonitrile solution (down). 

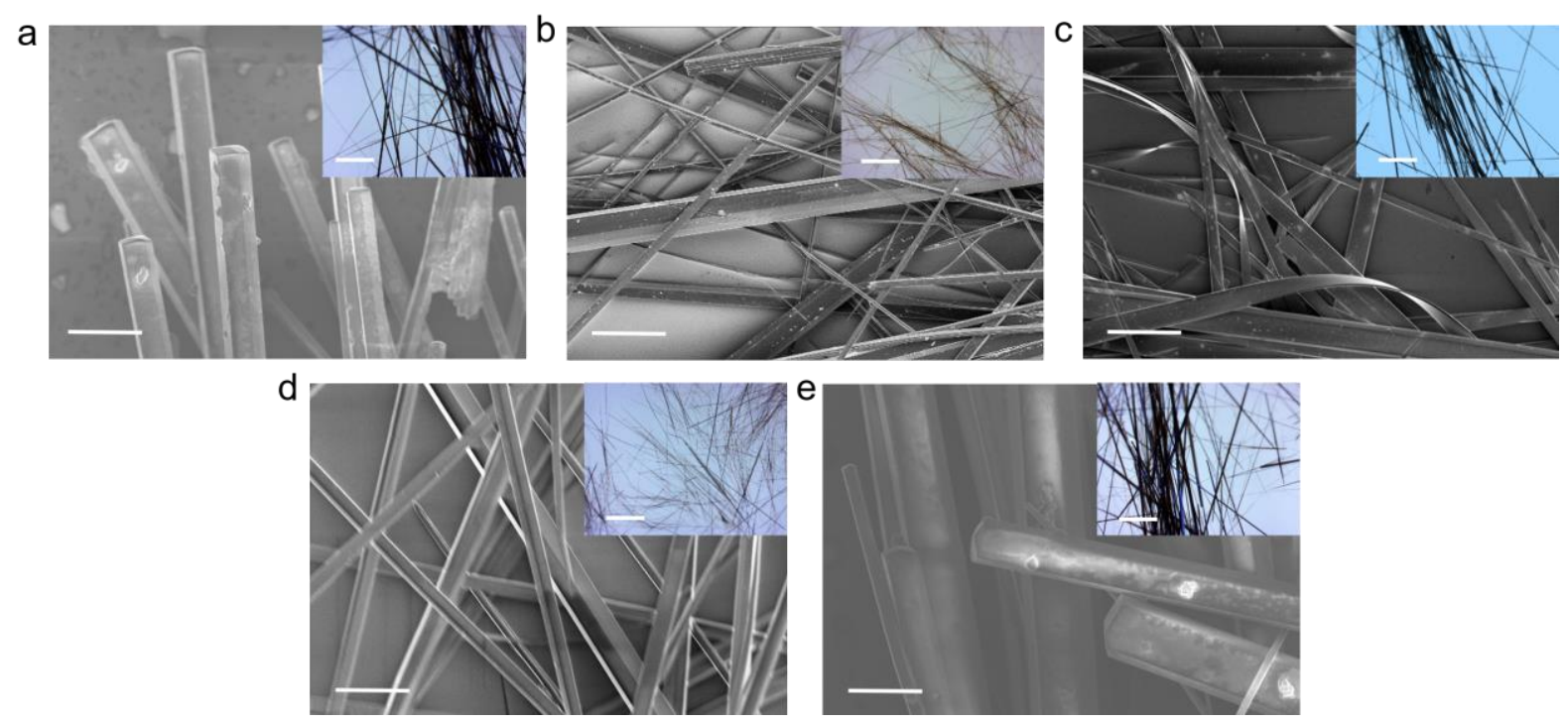

Figure S7. Scanning electron microscopy (SEM) (scale bar: $5 \mu \mathrm{m}$ ) and optical microscopy (OM) (inset, scale bar: $120 \mu \mathrm{m}$ ) images of (a) BDOPV, (b) $o-\mathrm{F}_{2}-\mathrm{BDOPV}$, (c) $p-\mathrm{F}_{2}-\mathrm{BDOPV}$, (d) $\mathrm{F}_{4}$-BDOPV and (e) $\mathrm{F}_{6}$-BDOPV crystals on silicon substrate. 

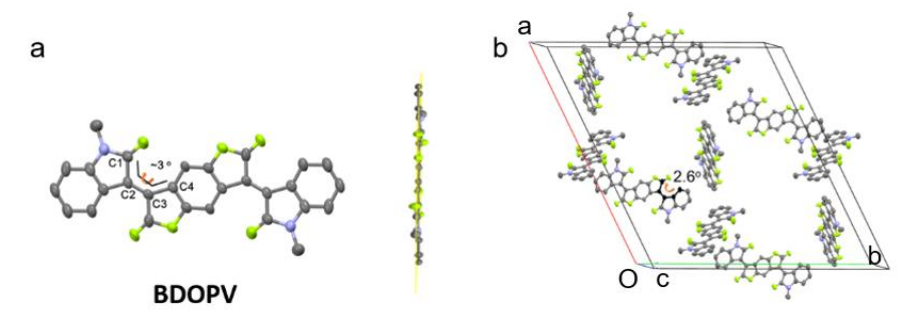

$$
\begin{aligned}
& a=37.3 \AA \\
& b=37.3 \AA \\
& c=6.47 \AA \\
& \alpha=90^{\circ} \\
& \beta=90^{\circ} \\
& y=120^{\circ}
\end{aligned}
$$

BDOPV

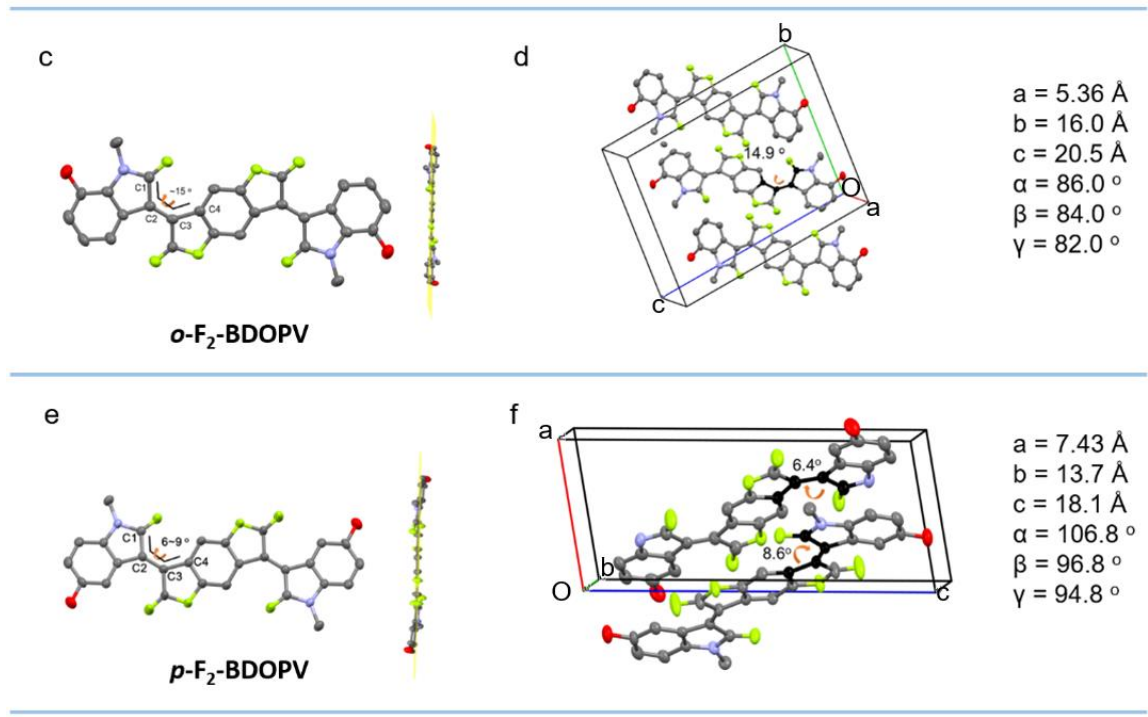

g

$\mathrm{h}$
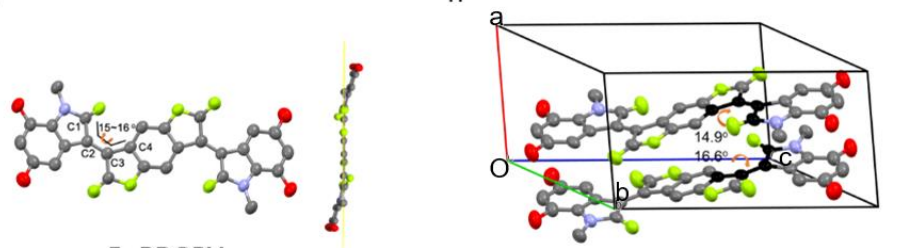

$a=7.21 \AA$ $b=14.4 \AA$ $c=18.6 \AA$ $\alpha=108.2^{\circ}$ $\beta=98.4^{\circ}$ $\mathrm{Y}=94.5^{\circ}$

\section{$F_{4}$-BDOPV}

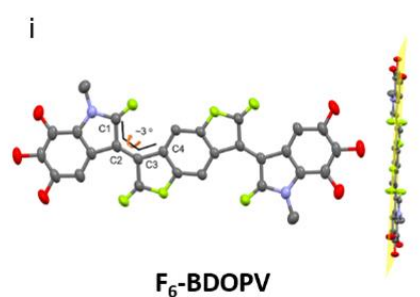

j

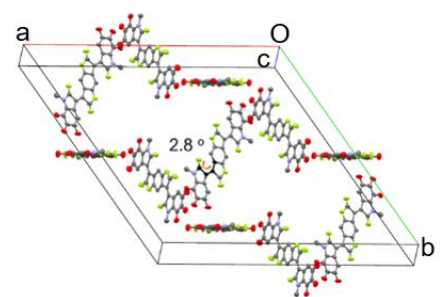

$a=37.9 \AA$

$\mathrm{b}=37.9 \AA$

$c=6.61 \AA$

$\alpha=90^{\circ}$

$\beta=90^{\circ}$

$\gamma=120^{\circ}$

Figure S8. Crystal structures and the dihedral angles in the exocyclic double bond position (C1-C2-C3-C4, isatin and 2,2'-(2,5-dihydroxy-1,4-phenylene)diacetic acid skeleton) of (a) BDOPV, (c) $o-\mathrm{F}_{2}-\mathrm{BDOPV}$, (e) $p-\mathrm{F}_{2}-\mathrm{BDOPV}$, (g) $\mathrm{F}_{4}-\mathrm{BDOPV}$ and (i) $\mathrm{F}_{6}-\mathrm{BDOPV}$. Crystal packing structures of (b) BDOPV, (d) $o-\mathrm{F}_{2}-\mathrm{BDOPV}$, (f) $p-\mathrm{F}_{2}-\mathrm{BDOPV}$, (h) $\mathrm{F}_{4}-\mathrm{BDOPV}$ and (j) $\mathrm{F}_{6}$-BDOPV respectively, the black regions in the crystal lattice means the dihedral angles. The red, yellow, purple, and grey coloured atoms represent $\mathrm{F}, \mathrm{O}, \mathrm{N}$, and $\mathrm{C}$ respectively (for clarity, the alkyl chain omitted). 


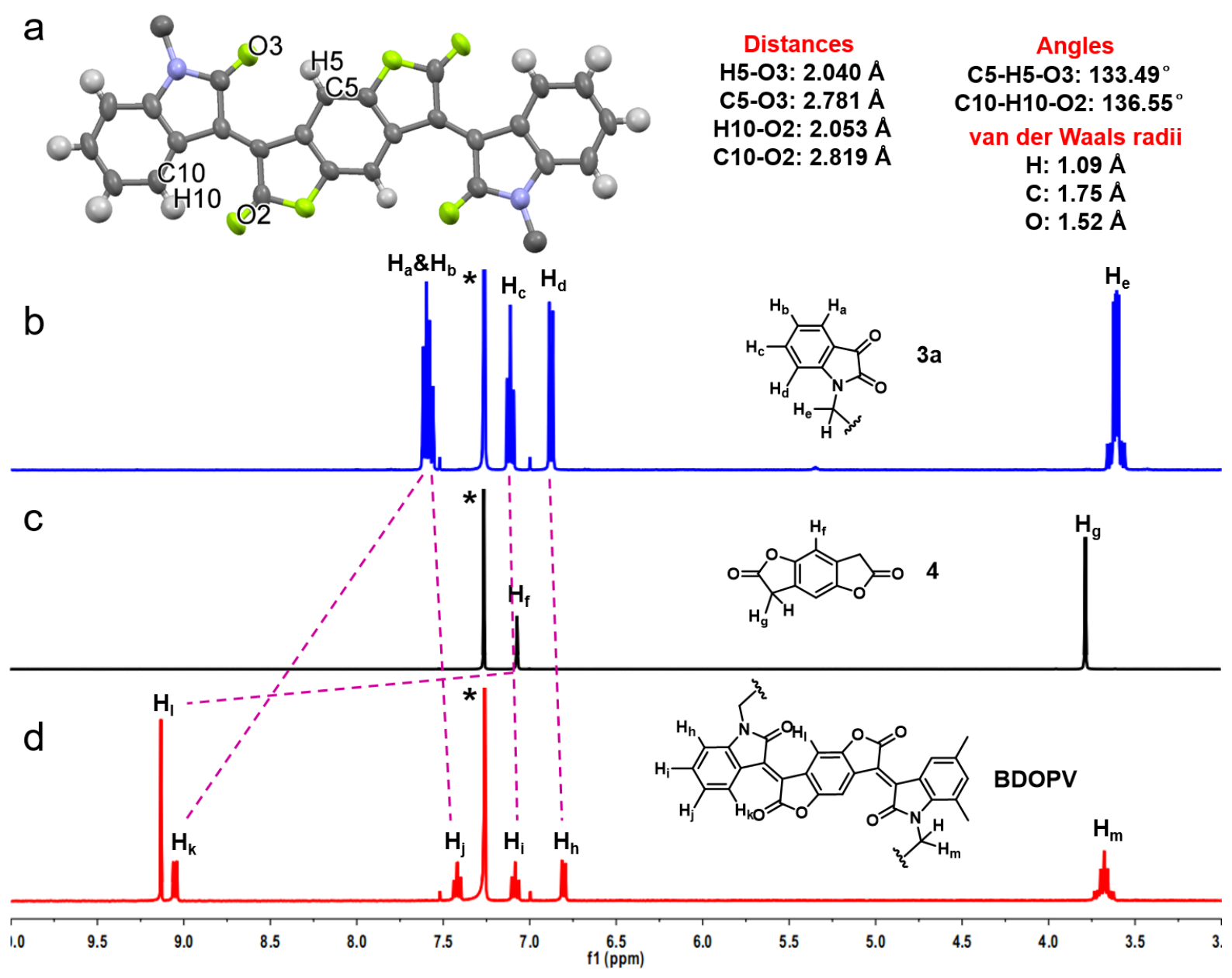

Figure S9. (a) Crystal structure of BDOPV and ${ }^{1} \mathrm{H}$ NMR spectra of (b) compound 3a, (c) compound 4, (d) BDOPV in $\mathrm{CDCl}_{3}\left(*: \mathrm{CDCl}_{3}\right)$.

The ${ }^{1} \mathrm{H}$ NMR spectrum of BDOPV clearly displayed five signals in the aromatic region, agreeing well with its chemical structure and chemical environment. After the condensation reaction, the signal of methylene $\left(\mathrm{H}_{\mathrm{g}}\right)$ in reactant 4 disappeared. In addition, the signal of $\mathrm{H}_{\mathrm{a}}$ of compound $3 \mathrm{a}$ obviously shifted from 7.61 to $9.06 \mathrm{ppm}\left(\mathrm{H}_{\mathrm{k}}\right.$ on BDOPV), and another signal of $\mathrm{H}_{\mathrm{f}}$ on the benzene ring of compound 4 significantly shifted from 7.07 to $9.13 \mathrm{ppm}\left(\mathrm{H}_{1}\right.$ on BDOPV). The downfield shift of $\mathrm{H}_{\mathrm{k}}$ and $\mathrm{H}_{1}$ on BDOPV indicate the formation of intramolecular hydrogen bonds between $\mathrm{H}_{\mathrm{k}} / \mathrm{H}_{1}$ and $\mathrm{O}$ on the carbonyl groups.

According to the previous report, the two standards for identifying hydrogen bonds from single crystal structures are that the H...A distance is substantially shorter than the sum of the van der Waals radii of $\mathrm{H}$ and $\mathrm{A}$, and that the angle between $\mathrm{X}-\mathrm{H}$...A is larger than $110^{\circ}$ (Angew. Chem. Int. Ed. 2002, 41, 48-76). The structure of BDOPV in single crystals displayed a planar backbone with dihedral angles of $\sim 3^{\circ}$ (Figure S8a). The C5-H5-O3 $\left(133.49^{\circ}\right)$ and $\mathrm{C} 10-\mathrm{H} 10-\mathrm{O} 2\left(136.55^{\circ}\right)$ angles are substantially larger than $110^{\circ}$, and the $\mathrm{C}-\mathrm{O}$ bond distances $(\sim 2.8 \AA)$ are shorter than the combined van der Waals radii $(3.27 \AA)$ (R. 
Taylor et al. J. Phys. Chem. 1996, 100, 7384). These results indicate that four intramolecular hydrogen bonds are formed in BDOPV (S. W. Bunte et al. J. Am. Chem. Soc. 1997, 119, 9083).

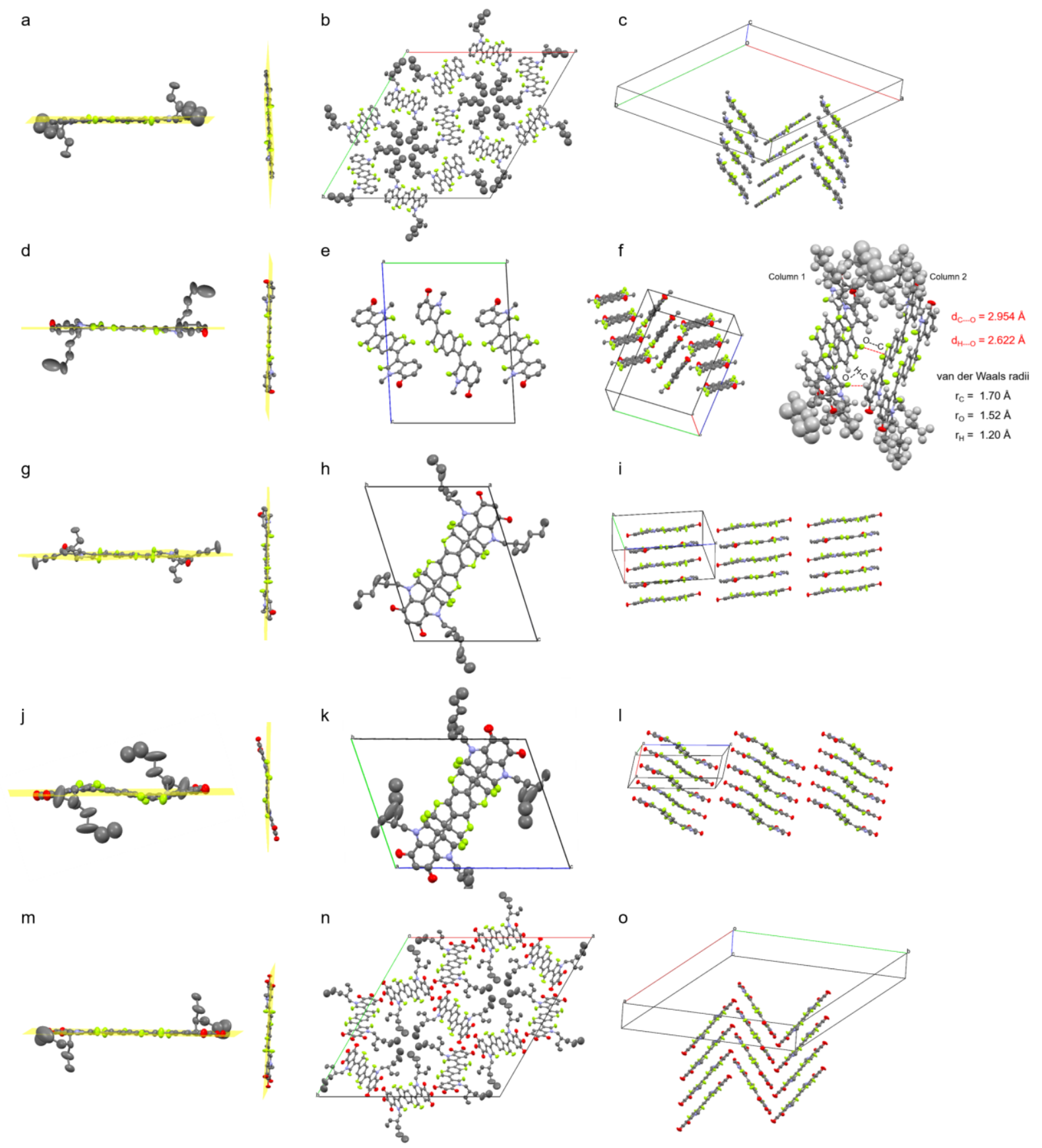

Figure S10. Molecular structure of (a) BDOPV, (d) $o-\mathrm{F}_{2}-\mathrm{BDOPV}$, (g) $p-\mathrm{F}_{2}-\mathrm{BDOPV}$, (j) $\mathrm{F}_{4}-$ BDOPV and (m) $\mathrm{F}_{6}$-BDOPV. (b, e, h, k, n) Crystal packing structures in one unit cell of five BDOPV derivatives. Crystal packing structures of (c) BDOPV, (f) $o-\mathrm{F}_{2}-\mathrm{BDOPV}$ (The distance between $\mathrm{C}-\mathrm{H}$ or $\mathrm{C}$ and $\mathrm{O}$ in $o-\mathrm{F}_{2}-\mathrm{BDOPV}$ single crystal packing is $2.622 \AA$ and 2.954 $\AA$, shorter than the sum of their van der Waals radii of $2.72 \AA$ and $3.22 \AA$, indicating the formation of $\mathrm{C}-\mathrm{H} \ldots \mathrm{O}$ and $\mathrm{C} \ldots \mathrm{O}$ interactions between columns), (i) $p-\mathrm{F}_{2}-\mathrm{BDOPV}$, (1) $\mathrm{F}_{4}-$ 
BDOPV and (o) $\mathrm{F}_{6}-\mathrm{BDOPV}$, respectively (for clarity, the alkyl chains were omitted). The red, green, blue, and grey coloured atoms represent $\mathrm{O}, \mathrm{F}, \mathrm{N}$, and $\mathrm{C}$ respectively.

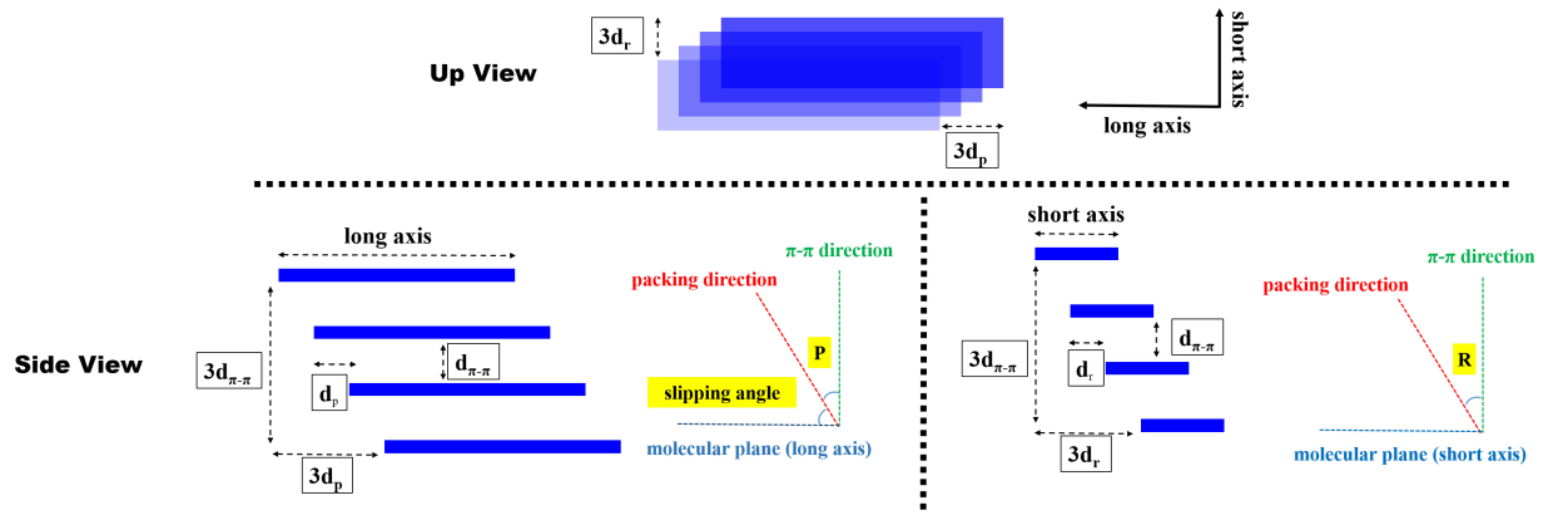

Figure S11. Definition of the pitch angle (P), slipping angle and roll angle (R) according to Curtius method (J. Am. Chem. Soc. 2009, 131, 6215). (left): View along the short molecular axis of a"pitched" $\pi$-stack. (right): View along the long molecular axis of a "rolled" $\pi$-stack.

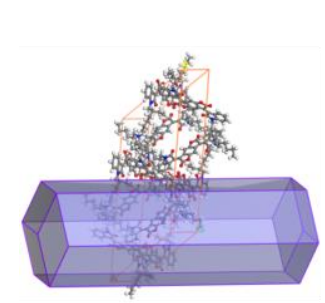

BDOPV

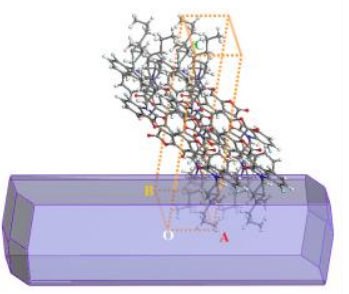

O-F $\mathrm{F}_{2}-\mathrm{BDOPV}$

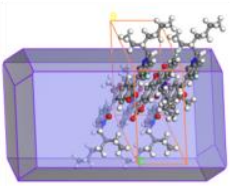

$p-F_{2}-B D O P V$

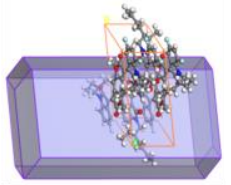

$\mathrm{F}_{4}-\mathrm{BDOPV}$

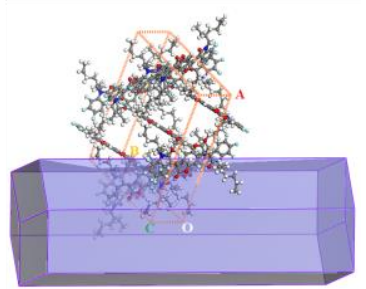

$F_{6}-$ BDOPV

Figure S12. Calculated BFDH crystal growth morphology of corresponding single crystals.

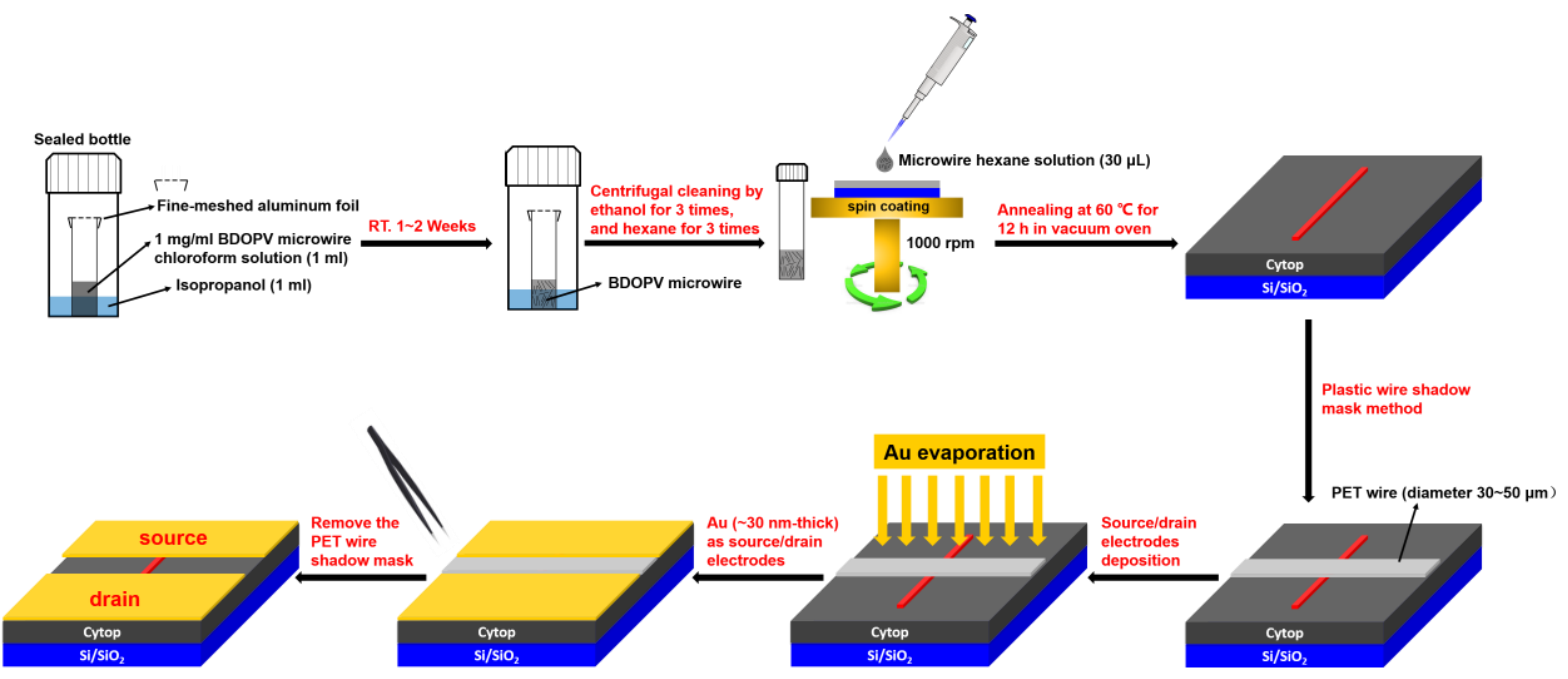

Figure S13. The diagram of SC-OFET device fabrication process. 
First, the single crystals were grown via solvent vapor diffusion. A bottle containing BDOPV solution in chloroform with concentration of $1 \mathrm{mg} / \mathrm{mL}$ was covered by a fine meshed aluminum foil. And this bottle was put inside a sealed bottle containing $1 \mathrm{~mL}$ of isopropanol. The dimension of single crystals could be controlled by the concentration of BDOPV chloroform solutions. The more dilute the solution is, the larger microwires will be obtained. After one to two weeks evaporation, small molecules self-assembled into single crystals with desired sizes. Before device fabrication, single crystals were centrifugally cleaned by ethanol for three times and then by hexane for three times. The SC-OFET devices were prepared via spin-coating from the dilute BDOPV microwires dispersion in hexane solution. After microwires were deposited on Cytop $(230 \mathrm{~nm})$ coated $\mathrm{n}^{++}-\mathrm{Si} / \mathrm{SiO}_{2}(300 \mathrm{~nm})$ substrates, the substrates with microwires were baked in the vacuum oven at $60{ }^{\circ} \mathrm{C}$ overnight. A polyethylene terephthalate (PET) fiber with 30 50 $\mu \mathrm{m}$ diameter was mounted across the microwires as shadow mask. A layer of $20 \mathrm{~nm}$ gold as source and drain electrode was first deposited onto the wires with speed of $0.05 \AA / s$. Then the substrate was rotated by $180^{\circ}$ with respect to the evaporation source, and a layer of $10 \mathrm{~nm}$ gold was deposited onto the wires with the speed of $0.15 \AA / s$. The pressure during thermal evaporation process was $4 \times 10^{-4} \mathrm{~Pa}$. After the deposition, the PET wire was removed before device measurement.
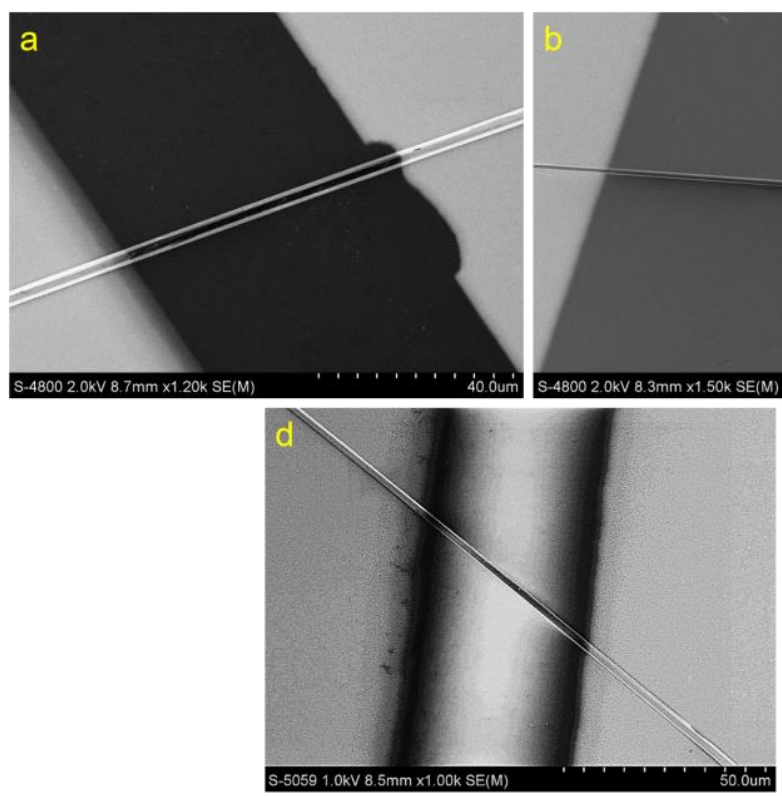
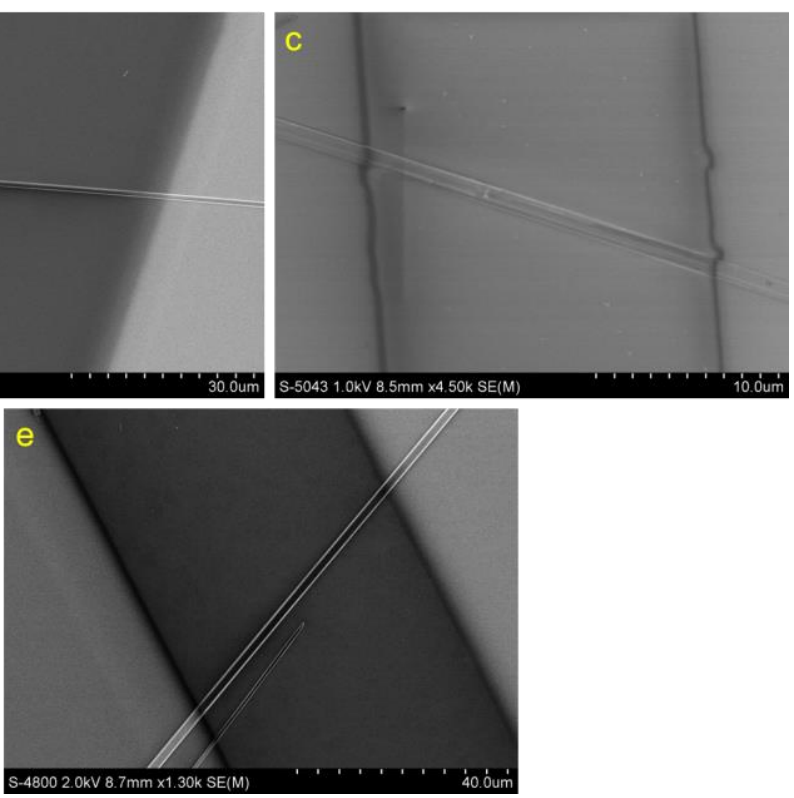

Figure S14. Scanning electron microscopy image of (a) BDOPV, (b) $o-\mathrm{F}_{2}-\mathrm{BDOPV}$, (c) $p-\mathrm{F}_{2}-$ BDOPV, (d) F-BDOPV and (e) $\mathrm{F}_{6}$-BDOPV SC-FETs with the highest electron mobility, shown in Figure 4. 

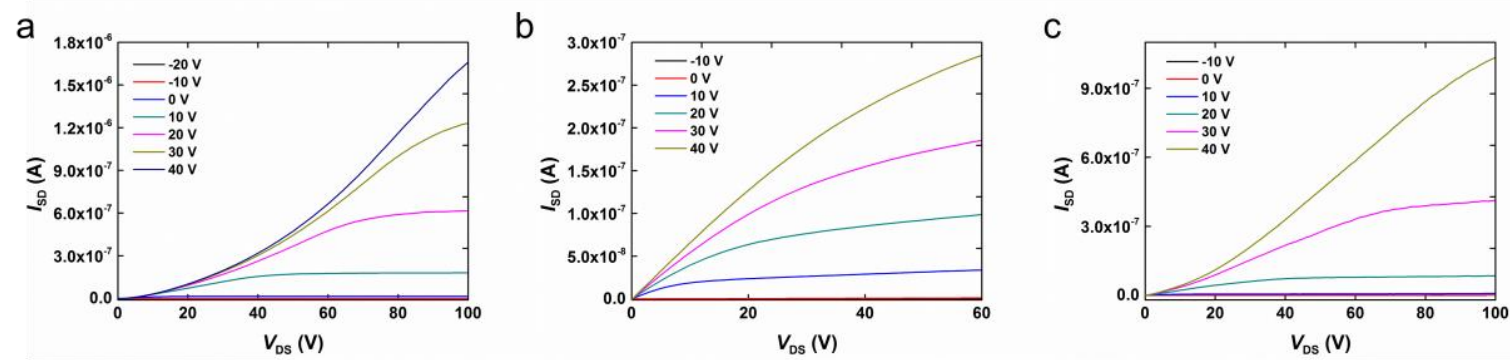

d
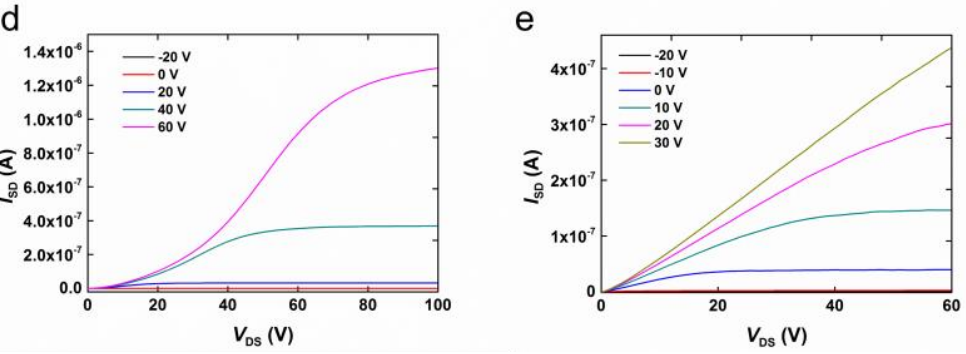

Figure S15. Out-put curves of the single-crystal field-effect transistor of (a) BDOPV, (b) $o$ $\mathrm{F}_{2}-\mathrm{BDOPV}$, (c) $p-\mathrm{F}_{2}-\mathrm{BDOPV}$, (d) $\mathrm{F}_{4}-\mathrm{BDOPV}$ and (e) $\mathrm{F}_{6}-\mathrm{BDOPV}$, corresponding to transfer curves shown in Figure 4. We note that in the output curves the rise of current with voltage in the low $V_{D}$ regime is slightly superquadratic, which may be caused by the contact resistance effects (Reference: B. H. Hamadani and D. Natelson, J. Appl. Phys. 2005, 97, 064508). This is also responsible for the decrease of $I_{\mathrm{ds}}$ in high $V_{\mathrm{g}}$ in transfer curves (Reference: $\mathrm{H}$. Sirringhaus, $A d v$. Mater. 2014, 26, 1319). Further optimization to eliminate the contact resistance effect is ongoing. 
a
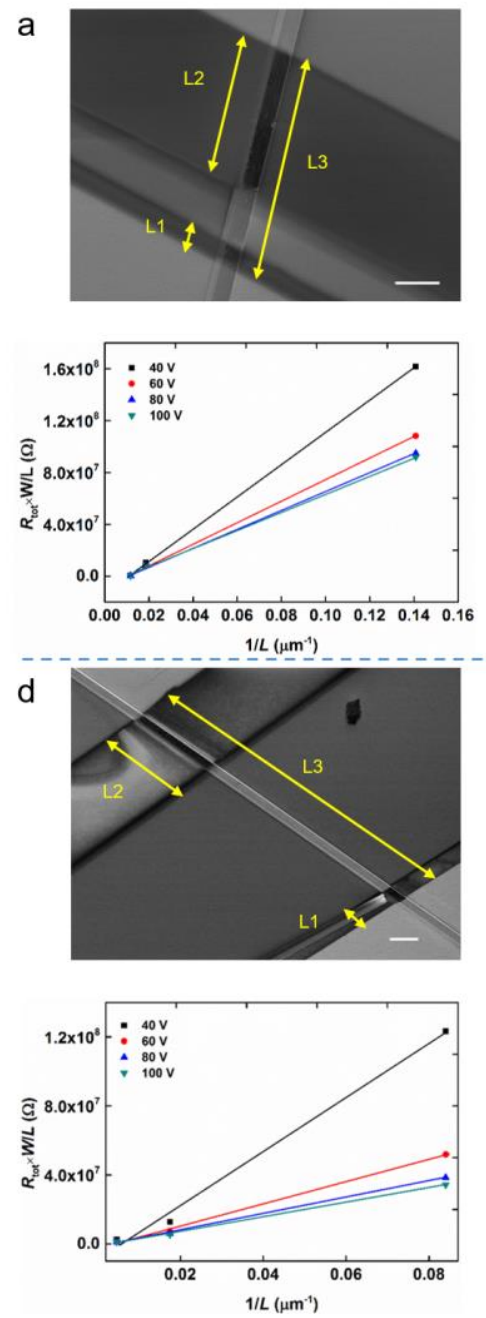

b
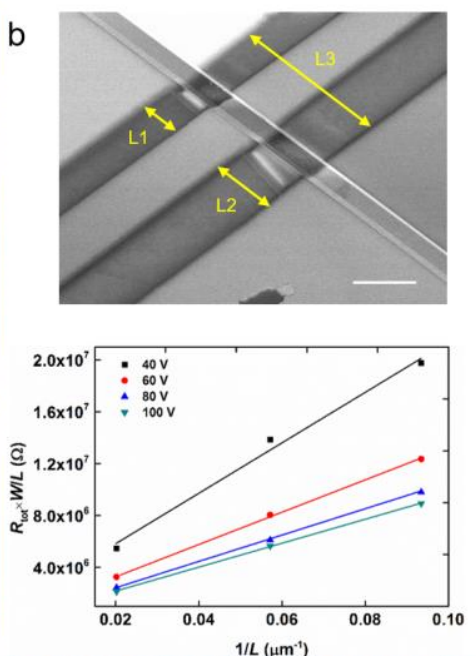

e
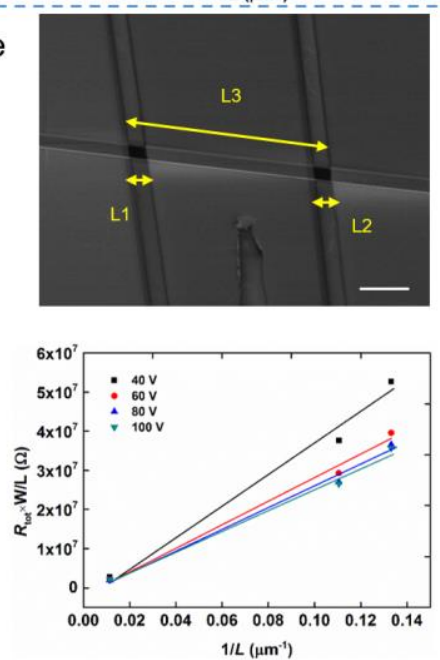
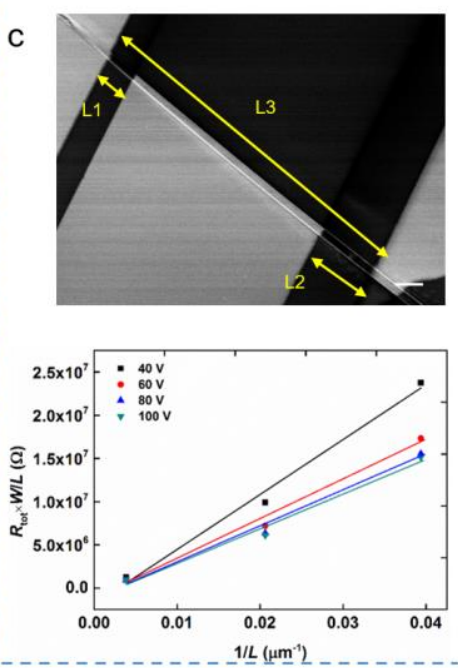

if

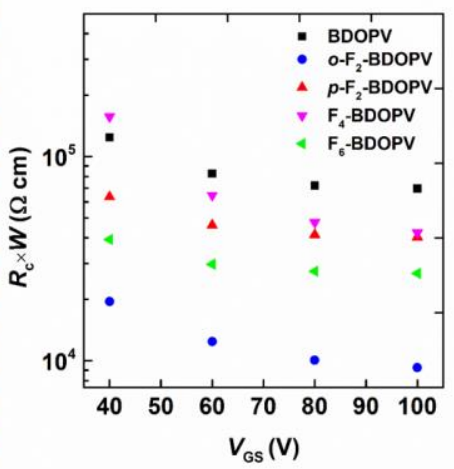

Figure S16. SEM images (up) and the M-TLM (down) at $V_{\mathrm{GS}}$ from 40 to $100 \mathrm{~V}$ of (a) BDOPV, (b) $o-\mathrm{F}_{2}-\mathrm{BDOPV}$, (c) $p-\mathrm{F}_{2}-\mathrm{BDOPV}$, (d) $\mathrm{F}_{4}$-BDOPV and (e) $\mathrm{F}_{6}-\mathrm{BDOPV}$ based SCOFET devices. (scale bar, $20 \mu \mathrm{m}$ ). (f) The contact resistance extracted by M-TLM of five molecules.

We measured the contact resistance of SC-OFET devices based on all the BDOPV derivatives to understand the contact resistances caused by different molecular packing. BDOPV, $p-\mathrm{F}_{2}-$ BDOPV, $\mathrm{F}_{4}$-BDOPV and $\mathrm{F}_{6}$-BDOPV adopt 1D stacking without intercolumn interactions, while $o-\mathrm{F}_{2}$-BDOPV adopts herringbone stacking with $15 \mathrm{meV}$ intercolumn transfer integral. We utilized modified transmission-line method (M-TLM) to calculate the contact resistance of two devices (Y. Xu, et al. Appl. Phys. Lett. 2010, 97, 063302; I. N. Hulea, et al. Appl. Phys. Lett. 2006, 88, 113512).

The contact resistances of SC-OFET devices of BDOPV, $p-\mathrm{F}_{2}-\mathrm{BDOPV}, \mathrm{F}_{4}-\mathrm{BDOPV}$ and $\mathrm{F}_{6}$ BDOPV are calculated to be $6.9 \times 10^{4}, 4 \times 10^{4}, 4.2 \times 10^{4}$, and $2.6 \times 10^{4} \Omega \mathrm{cm}$, at $V_{\mathrm{GS}}=100 \mathrm{~V}$. In contrast, for $o-\mathrm{F}_{2}-\mathrm{BDOPV}$ with herringbone stacking, the contact resistance is clearly lower than those of all the other molecules, estimated to be about $9.3 \times 10^{3} \Omega \mathrm{cm}$ at $V_{\mathrm{GS}}=100 \mathrm{~V}$. 
This may be benefit from its intercolumn interactions. Besides, the contact resistance of rubrene, adopting herringbone stacking with intercolumn interactions, is generally reported to be around $10^{2} \sim 10^{3} \Omega \mathrm{cm}$, lower than those of BDOPV derivatives (I. N. Hulea, et al. Appl. Phys. Lett. 2006, 88, 113512; A. F. Morpurgo, et al. Appl. Phys. Lett. 2007, 90, 212103).
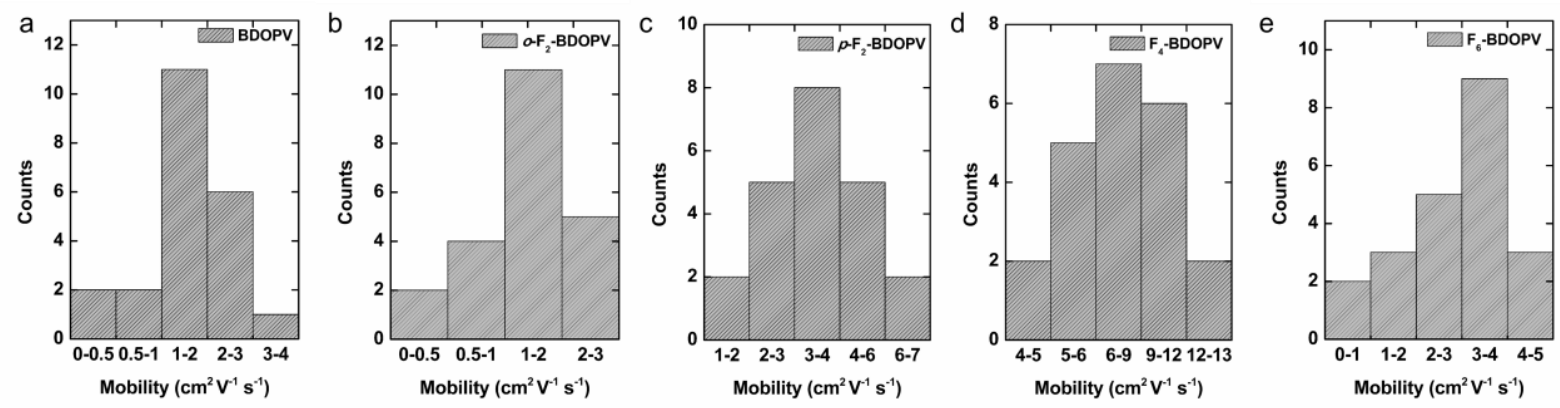

Figure S17. Histograms of (a) BDOPV, (b) $o-\mathrm{F}_{2}-\mathrm{BDOPV}$, (c) $p-\mathrm{F}_{2}-\mathrm{BDOPV}$, (d) $\mathrm{F}_{4}-\mathrm{BDOPV}$ and (e) $\mathrm{F}_{6}$-BDOPV electron mobility measured under ambient conditions obtained from 22 transistors respectively.

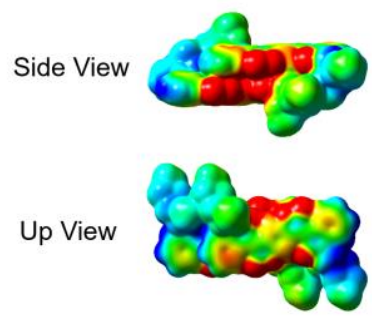

Dimer-ESP-BDOPY

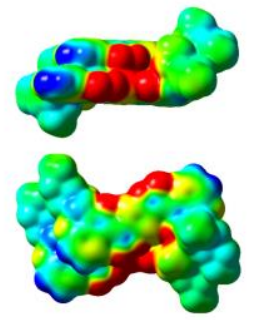

Dimer-ESP-o-F - -BDOPV

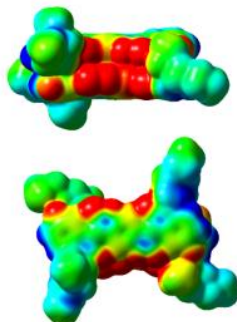

Dimer-ESP-p-F-BDOPY
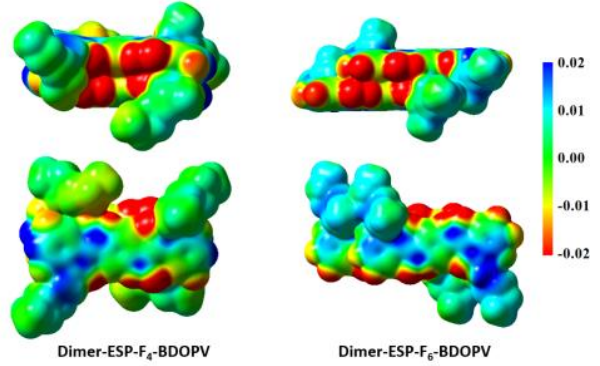

Dimer-ESP-F F $_{6}$ BDOPV

Figure S18. Calculated ESPs of two adjacent molecules along $\pi$ - $\pi$-stacking direction, placed in the stacking geometry (up: side view, down: up view).

Table S1. Summary of Photophysical and Electrochemical Properties of Five Molecules

\begin{tabular}{llllllll}
\hline Molecules & $\begin{array}{l}T_{\mathrm{d}}{ }^{a} / T_{\mathrm{m}} \\
\left({ }^{\circ} \mathrm{C}\right)\end{array}$ & $\begin{array}{l}\lambda_{\max } \mathrm{Sol}^{b} \\
(\mathrm{~nm})\end{array}$ & $\begin{array}{l}\lambda_{\max } \text { film } \\
(\mathrm{nm})\end{array}$ & $\begin{array}{l}E_{\mathrm{g}}{ }^{\mathrm{opt}}(\mathrm{eV})^{c} \\
(\mathrm{Sol} / \mathrm{Film})\end{array}$ & $\begin{array}{l}E_{\mathrm{HOMO}}(\mathrm{eV})^{d} \\
(\mathrm{Sol} / \mathrm{Film})\end{array}$ & $\begin{array}{l}E_{\mathrm{LUMO}}(\mathrm{eV})^{d} \\
(\mathrm{Sol} / \mathrm{Film})\end{array}$ & $\begin{array}{l}E_{\mathrm{g}}{ }^{\mathrm{cv}}(\mathrm{eV})^{e} \\
(\mathrm{Sol} / \mathrm{Film})\end{array}$ \\
\hline BDOPV & $336 / 256$ & 555,446 & 629,425 & $1.82 / 1.63$ & $-5.95 /-6.05$ & $-4.19 /-3.96$ & $1.76 / 2.09$ \\
$o-\mathrm{F}_{2}-\mathrm{BDOPV}$ & $331 / 222$ & 540,455 & 522,435 & $1.74 / 1.69$ & $-6.10 /-6.14$ & $-4.20 /-4.16$ & $1.89 / 1.98$ \\
$p-\mathrm{F}_{2}$-BDOPV & $346 / 209$ & 536,443 & 528,421 & $1.76 / 1.51$ & $-6.04 /-6.06$ & $-4.21 /-4.35$ & $1.83 / 1.71$ \\
$\mathrm{~F}_{4}-\mathrm{BDOPV}$ & $334 / 227$ & 530,451 & 550,440 & $1.80 / 1.49$ & $-6.09 /-6.18$ & $-4.37 /-4.44$ & $1.72 / 1.65$ \\
$\mathrm{~F}_{6}$-BDOPV & $346 / 200$ & 563,447 & 523,433 & $1.83 / 1.59$ & $-6.09 /-6.18$ & $-4.34 /-4.44$ & $1.75 / 1.73$ \\
\hline
\end{tabular}

${ }^{a}$ Molecular 5\% loss weights evaluated by TGA in nitrogen. ${ }^{b} 10^{-5} \mathrm{M}$ in chloroform. ${ }^{c}$ Estimated from the onset of the absorption. ${ }^{d} \mathrm{CV}$ determined with $\mathrm{Fc} / \mathrm{Fc}^{+}\left(E_{\text {номо }}=-4.80 \mathrm{eV}\right)$ as external reference. ${ }^{e} E_{\mathrm{g}}{ }^{\mathrm{CV}}=E_{\mathrm{LUMO}}-E_{\text {номо }}$. 
Table S2. Crystallographic Data of Five Molecules.

\begin{tabular}{|c|c|c|c|c|c|}
\hline $\begin{array}{l}\text { Compound } \\
\text { Reference }\end{array}$ & BDOPV & $o-\mathrm{F}_{2}-\mathrm{BDOPV}$ & $p-\mathrm{F}_{2}-\mathrm{BDOPV}$ & $\mathrm{F}_{4}$-BDOPV & F $_{6}-\mathrm{BDOPV}$ \\
\hline Empirical formula & $\mathrm{C} 42 \mathrm{H} 44 \mathrm{~N} 2 \mathrm{O} 6$ & $\mathrm{C} 42 \mathrm{H} 42 \mathrm{~F} 2 \mathrm{~N} 2 \mathrm{O} 6$ & $\mathrm{C} 42 \mathrm{H} 42 \mathrm{~F} 2 \mathrm{~N} 2 \mathrm{O} 6$ & $\mathrm{C} 42 \mathrm{H} 40 \mathrm{~F} 4 \mathrm{~N} 2 \mathrm{O} 6$ & C42H38F6N2O6 \\
\hline Formula weight & 672.79 & 708.77 & 708.77 & 744.76 & 780.75 \\
\hline Wavelength (̊̊) & 0.71073 (Mo Kla) & 0.71073 (Mo Kla) & 0.71073 (Mo Kla) & $1.54184(\mathrm{Cu} \mathrm{Kla})$ & $1.54178(\mathrm{Cu} \mathrm{Kla})$ \\
\hline Crystal size (mm) & $0.15 \times 0.10 \times 0.10$ & $0.05 \times 0.01 \times 0.01$ & $0.05 \times 0.01 \times 0.01$ & $0.5 \times 0.06 \times 0.02$ & $0.15 \times 0.10 \times 0.10$ \\
\hline Crystal system & trigonal & triclinic & triclinic & triclinic & trigonal \\
\hline Space group & R-3 & P-1 & P-1 & P-1 & R-3 \\
\hline$a(\AA)$ & $37.317(8)$ & $5.3586(2)$ & $7.4347(5)$ & $7.2121(2)$ & $37.9197(10)$ \\
\hline$b(\AA)$ & $37.317(8)$ & $15.9637(12)$ & 13.6894(10) & $14.4102(7)$ & $37.9197(10)$ \\
\hline$c(\AA)$ & $6.4679(13)$ & $20.5234(11)$ & $18.0508(12)$ & $18.5578(8)$ & $6.6101(2)$ \\
\hline$\alpha\left(^{\circ}\right)$ & 90 & $85.975(5)$ & $106.793(6)$ & $108.180(4)$ & 90 \\
\hline$\beta\left({ }^{\circ}\right)$ & 90 & $83.990(4)$ & $96.814(6)$ & $98.418(3)$ & 90 \\
\hline$\gamma\left({ }^{\circ}\right)$ & 120 & $82.010(5)$ & $94.792(6)$ & $94.465(3)$ & 120 \\
\hline $\begin{array}{l}\text { Unit cell volume } \\
\qquad\left(\AA^{3}\right)\end{array}$ & $7800(4)$ & $1726.27(17)$ & $1732.9(2)$ & $1796.93(13)$ & $8231.3(4)$ \\
\hline $\begin{array}{c}\text { Density (calc) }(\mathrm{g} \\
\left.\mathbf{c m}^{-3}\right)\end{array}$ & 1.289 & 1.364 & 1.358 & 1.377 & 1.418 \\
\hline $\begin{array}{l}\text { Single moleculer } \\
\text { long axis }(\AA)\end{array}$ & 16.4 & 16.4 & 16.4 & 16.4 & 16.4 \\
\hline $\begin{array}{l}\text { Single moleculer } \\
\text { short axis }(\AA)\end{array}$ & 4.62 & 4.62 & 4.62 & 4.62 & 4.62 \\
\hline $\begin{array}{l}\text { torsion angle } \\
\text { (degree) }\end{array}$ & 2.62 & $13.09(9.71)$ & $8.62(6.44)$ & $16.55(14.89)$ & 3.02 \\
\hline Temperature (K) & $180(10)$ & $180(1)$ & $180(10)$ & $180(2)$ & $180(10)$ \\
\hline $\begin{array}{l}\text { No. of formula } \\
\text { units per unit cell }\end{array}$ & 9 & 2 & 2 & 2 & 9 \\
\hline $\begin{array}{c}\text { Completeness to } \\
\text { theta }\end{array}$ & $\begin{array}{c}0.977(\text { theta }= \\
25.242)\end{array}$ & $0.995($ theta $=26.37)$ & $\begin{array}{l}0.955(\text { theta }= \\
25.242)\end{array}$ & $0.972($ theta $=74.48)$ & $0.973($ theta $=73.83)$ \\
\hline $\begin{array}{l}\text { Largest diff. peak } \\
\text { and hole }\left(\AA^{-3}\right)\end{array}$ & 0.272 and -0.231 & 0.569 and -0.393 & 0.731 and -0.435 & 0.734 and -0.330 & 0.448 and -0.357 \\
\hline $\begin{array}{c}\text { No. of reflections } \\
\text { measured }\end{array}$ & 5382 & 13584 & 10179 & 20046 & 10039 \\
\hline $\begin{array}{l}\text { No. of independent } \\
\text { reflections }\end{array}$ & 3336 & 7014 & 5992 & 7137 & 3610 \\
\hline Rint & 0.1317 & 0.0780 & 0.0501 & 0.052 & 0.0288 \\
\hline GooF & 0.969 & 1.010 & 1.020 & 1.013 & 1.058 \\
\hline $\begin{array}{l}\text { Final R1 values (I } \\
\qquad 2 \sigma(I))\end{array}$ & 0.0870 & 0.0953 & 0.0806 & 0.1053 & 0.0602 \\
\hline $\begin{array}{c}\text { Final wR(F2) } \\
\text { values }(\mathrm{I}>\mathbf{2 \sigma ( I ) )}\end{array}$ & 0.1164 & 0.2064 & 0.1942 & 0.3005 & 0.1760 \\
\hline CCDC & 1428031 & 1428035 & 1428036 & 1405775 & 1428034 \\
\hline
\end{tabular}

Table S3. Reorganization Energy in Gas Phase (in eV)

\begin{tabular}{ccccccccccc}
\hline & BDOPV & $\begin{array}{c}o-\mathrm{F}_{2-} \\
\text { BDOPV }\end{array}$ & $\begin{array}{c}p-\mathrm{F}_{2^{-}} \\
\text {BDOPV }\end{array}$ & $\begin{array}{c}\mathrm{F}_{4^{-}} \\
\text {BDOPV }\end{array}$ & $\begin{array}{c}\mathrm{F}_{6-} \\
\text { BDOPV }\end{array}$ & $\begin{array}{c}\text { BDOPV- } \\
\mathrm{Me}\end{array}$ & $\begin{array}{c}o-\mathrm{F}_{2^{-}} \\
\mathrm{BDOPV}- \\
\mathrm{Me}\end{array}$ & $\begin{array}{c}p-\mathrm{F}_{2}- \\
\text { BDOPV- } \\
\mathrm{Me}\end{array}$ & $\begin{array}{c}\mathrm{F}_{4^{-}} \\
\text {BDOPV- } \\
\mathrm{Me}\end{array}$ & $\begin{array}{c}\mathrm{F}_{6-} \\
\text { BDOPV- } \\
\mathrm{Me}\end{array}$ \\
\hline$\lambda_{\mathrm{e}}$ & 0.337 & 0.348 & 0.347 & 0.364 & 0.355 & 0.327 & 0.339 & 0.338 & 0.353 & 0.354 \\
$\lambda_{\mathrm{h}}$ & 0.260 & 0.251 & 0.226 & 0.223 & 0.268 & 0.259 & 0.253 & 0.220 & 0.214 & 0.271 \\
\hline
\end{tabular}




\section{Synthetic procedures and characterization}

The compounds $\mathbf{3 b}, \mathbf{1 c}$ and $\mathbf{1 d}$ are commercially available from J\&K (Beijing) Scientific Ltd. (http://www.jkchemical.com/). The compounds $\mathbf{1 e}$ and $\mathbf{8}$ are commercially available from InnoChem (Beijing) Science \& Technology Co., Ltd. (http://www.inno-chem.com.cn/). The compound 3a is commercially available from Lyn (Beijing) Science \& Technology Co., Ltd. (http://www.lyntech.cn/). The compound $\mathbf{6}$ was synthesized according to the literature. ${ }^{1,2}$

\section{Overview}

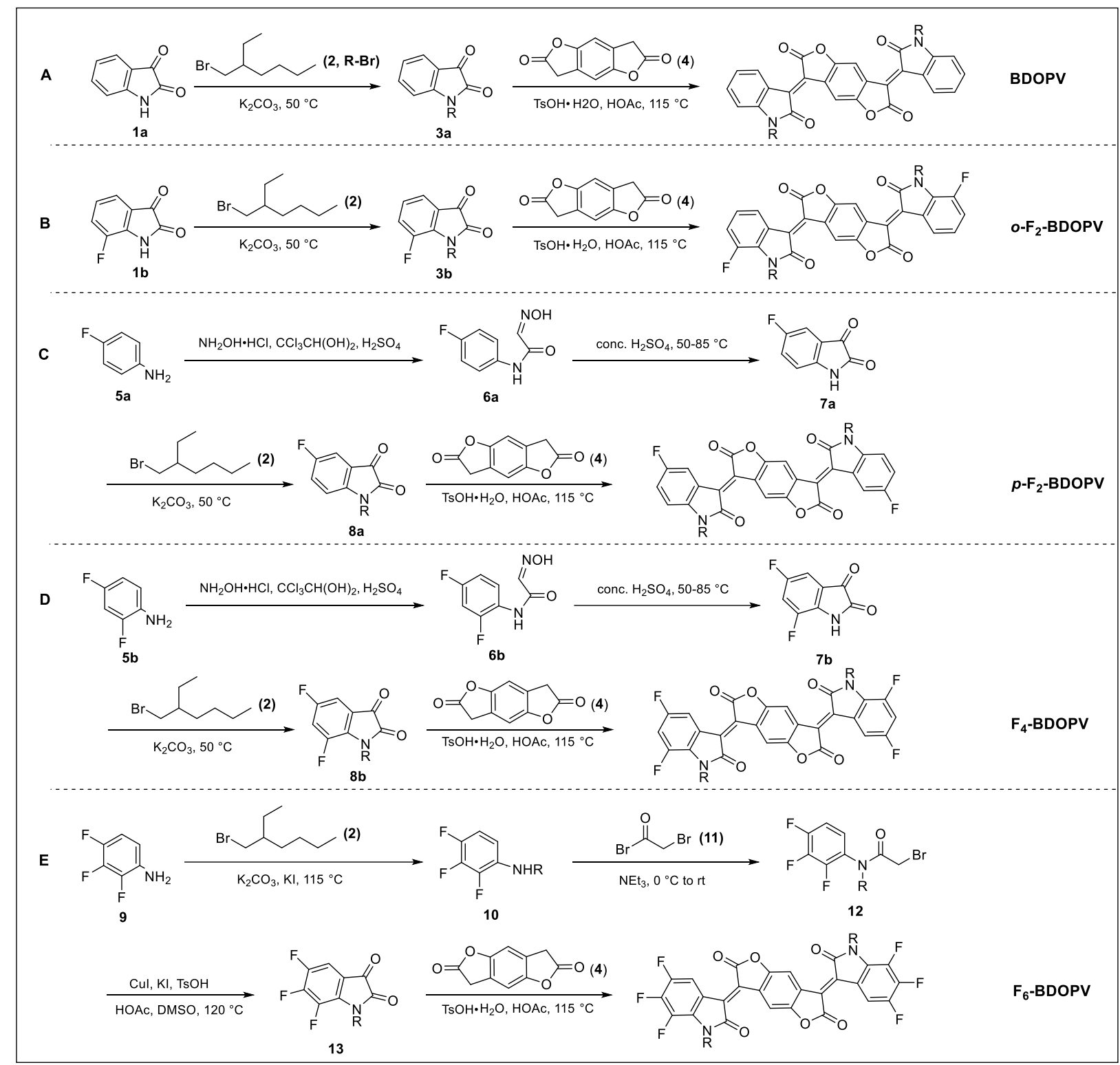




\section{A. Synthesis of BDOPV}

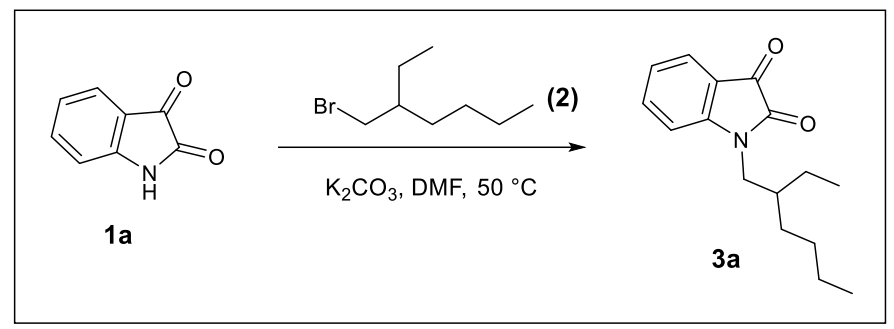

Isatin-EH (3a): To a solution of 3-(bromomethyl)heptane $(2,1.12 \mathrm{~g}, 6.0 \mathrm{mmol})$ in $N, N^{\prime}-$ dimethylformamide (DMF) $(30 \mathrm{~mL})$, Isatin $(\mathbf{1 a}, 0.74 \mathrm{~g}, 5.0 \mathrm{mmol})$, and $\mathrm{K}_{2} \mathrm{CO}_{3}(1.04 \mathrm{~g}, 7.5$ mmol) was added. The mixture was stirred at $50{ }^{\circ} \mathrm{C}$ for $12 \mathrm{~h}$ and then the solvents were removed under reduced pressure. The residues were dissolved in $\mathrm{CHCl}_{3}(100 \mathrm{~mL})$ and then washed with water and brine, and dried over with $\mathrm{Na}_{2} \mathrm{SO}_{4}$. After removal of the solvents under reduced pressure, the residue was purified by silica gel chromatography with eluent (PE: $\left.\mathrm{CH}_{2} \mathrm{Cl}_{2}=2: 1\right)$ to give an orange solid. Reaction Yield: $65 \% .{ }^{1} \mathrm{H} \mathrm{NMR}\left(\mathrm{CDCl}_{3}, 500 \mathrm{MHz}\right.$, ppm): $\delta 7.61-7.55(\mathrm{~m}, 2 \mathrm{H}), 7.12-7.09(\mathrm{t}, J=7.5 \mathrm{~Hz}, 1 \mathrm{H}), 6.88-6.87(\mathrm{~d}, J=7.9 \mathrm{~Hz}, 1 \mathrm{H})$, 3.65-3.57 (m, 2H), 1.84-1.79 (m, 1H), 1.42-1.26 (m, 8H), 0.95-0.88 (m, 6H). ${ }^{13} \mathrm{C}$ NMR $\left(\mathrm{CDCl}_{3}, 125 \mathrm{MHz}, \mathrm{ppm}\right): \delta 183.57,158.48,151.51,138.19,125.35,123.52,117.67,110.34$, 44.40, 37.37, 30.64, 28.62, 23.99, 22.98, 13.98, 10.55. ESI-HRMS calcd. for $\mathrm{C}_{16} \mathrm{H}_{22} \mathrm{NO}_{2}([\mathrm{M}$ $\left.+\mathrm{H}]^{+}\right): 260.1645 ;$ Found: 260.1645 .

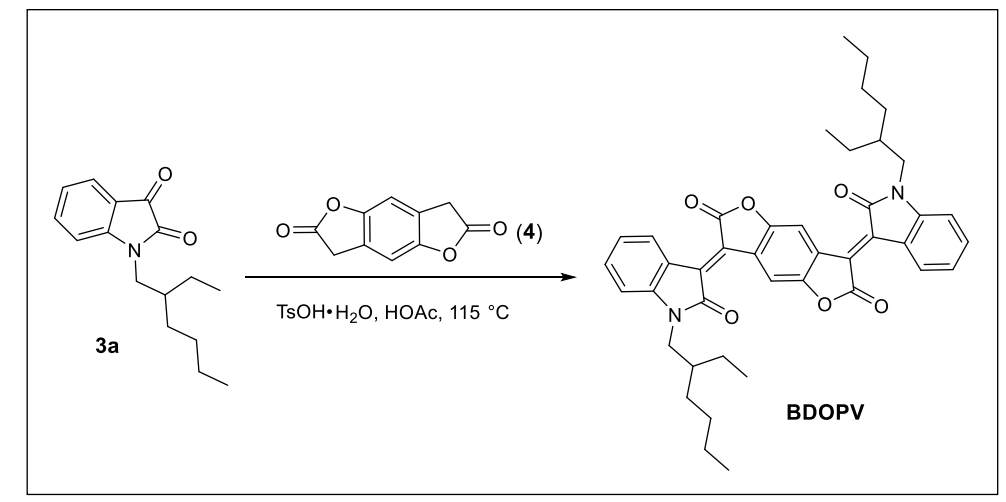

BDOPV: To a solution of Isatin-EH (3a, 389mg, $1.5 \mathrm{mmol})$ in acetic acid (25 mL), 4 (143 $\mathrm{mg}, 0.75 \mathrm{mmol})$ and toluenesulfonic acid monohydrate $(38 \mathrm{mg}, 0.20 \mathrm{mmol})$ was added. The mixture was stirred at $115^{\circ} \mathrm{C}$ under nitrogen atmosphere for $17 \mathrm{~h}$, and then cooled to room 
temperature and filtered. After washed with acetic acid and methanol, the filtration residues were dissolved in $\mathrm{CHCl}_{3}(100 \mathrm{~mL})$. After removal of the solvents under reduced pressure, the residue was purified by silica gel chromatography with eluent $\left(\mathrm{PE}: \mathrm{CH}_{2} \mathrm{Cl}_{2}=2: 1\right)$ to give a black solid. Reaction Yield: 61\%. ${ }^{1} \mathrm{H} \mathrm{NMR}\left(\mathrm{CDCl}_{3}, 400 \mathrm{MHz}, \mathrm{ppm}\right): \delta 9.13$ (s, 2H), 9.06$9.04(\mathrm{~d}, J=7.3 \mathrm{~Hz}, 2 \mathrm{H}), 7.44-7.40(\mathrm{~m}, 2 \mathrm{H}), 7.10-7.06(\mathrm{~m}, 2 \mathrm{H}), 6.81-6.79(\mathrm{~d}, J=7.6 \mathrm{~Hz}, 2 \mathrm{H})$, $3.73-3.62(\mathrm{~m}, 4 \mathrm{H}), 1.90-1.83(\mathrm{~m}, 2 \mathrm{H}), 1.40-1.31(\mathrm{~m}, 16 \mathrm{H}), 0.97-0.88(\mathrm{~m}, 12 \mathrm{H}) .{ }^{13} \mathrm{C}$ NMR $\left(\mathrm{CDCl}_{3}, 125 \mathrm{MHz}, \mathrm{ppm}\right): \delta 167.51,167.24,151.76,146.49,137.16,134.22,130.50,126.90$, $126.39,122.69,121.11,110.93,108.69,44.34,37.59,30.74,28.70,24.12,23.04,14.03$, 10.67. Elemental Anal. calcd. for $\mathrm{C}_{42} \mathrm{H}_{44} \mathrm{~N}_{2} \mathrm{O}_{6}$ : C, 74.98; H, 6.59; N, 4.16; Found: C, 75.04; H, 6.59; N, 4.13. ESI-HRMS calcd. for $\mathrm{C}_{42} \mathrm{H}_{45} \mathrm{~N}_{2} \mathrm{O}_{6}\left([\mathrm{M}+\mathrm{H}]^{+}\right)$: 673.3272; Found: 673.3262 .

\section{B. Synthesis of $o-F_{2}-B D O P V$}

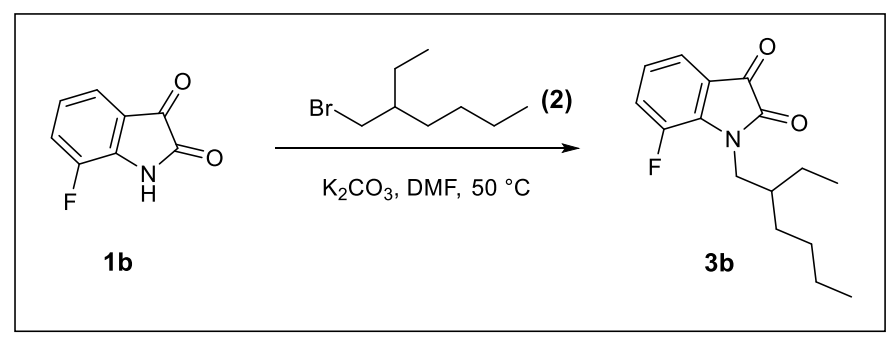

7-F-Isatin-EH (3b): To a solution of the 3-(bromomethyl)heptane (2, $1.35 \mathrm{~g}, 7.0 \mathrm{mmol})$ in $N, N$ '-dimethylformamide (DMF) (30 mL), 7-F-isatin (1b, $0.96 \mathrm{~g}, 5.8 \mathrm{mmol})$, and $\mathrm{K}_{2} \mathrm{CO}_{3}$ (1.21 g, $8.7 \mathrm{mmol}$ ) was added. The mixture was stirred at $50{ }^{\circ} \mathrm{C}$ for $17 \mathrm{~h}$ and then the solvents were removed under reduced pressure. The residues were dissolved in $\mathrm{CHCl}_{3}(100 \mathrm{~mL})$ and then washed with water and brine, and dried over with $\mathrm{Na}_{2} \mathrm{SO}_{4}$. After removal of the solvents under reduced pressure, the residue was purified by silica gel chromatography with eluent (PE: $\left.\mathrm{CH}_{2} \mathrm{Cl}_{2}=2: 1\right)$ to give an orange solid. Reaction Yield: $63 \% .{ }^{1} \mathrm{H} \mathrm{NMR}\left(\mathrm{CD}_{2} \mathrm{Cl}_{2}, 400 \mathrm{MHz}\right.$, ppm): $\delta 7.41-7.39(\mathrm{~d}, J=7.5 \mathrm{~Hz}, 1 \mathrm{H}), 7.36-7.31\left(\mathrm{dd}, J_{1}=11.7 \mathrm{~Hz}, J_{2}=8.3 \mathrm{~Hz}, 1 \mathrm{H}\right), 7.09-$ $7.04(\mathrm{~m}, 1 \mathrm{H}), 3.74-3.70(\mathrm{~m}, 2 \mathrm{H}), 1.79-1.77(\mathrm{~m}, 1 \mathrm{H}), 1.38-1.27(\mathrm{~m}, 8 \mathrm{H}), 0.89-0.82(\mathrm{~m}, 6 \mathrm{H})$. ${ }^{13} \mathrm{C}$ NMR $\left(\mathrm{CD}_{2} \mathrm{Cl}_{2}, 100 \mathrm{MHz}, \mathrm{ppm}\right): \delta 182.34,158.52,149.57,147.11,137.71,127.01$, $126.85,124.86,121.50,120.80,46.84,39.00,30.71,30.67,28.83,24.01,23.97,23.41,14.20$, 
14.16, 10.57. ESI-HRMS calcd. for $\mathrm{C}_{16} \mathrm{H}_{21} \mathrm{FNO}_{2}\left([\mathrm{M}+\mathrm{H}]^{+}\right)$: 278.1551; Found: 278.1555 and for $\mathrm{C}_{16} \mathrm{H}_{20} \mathrm{FNNaO}_{2}\left([\mathrm{M}+\mathrm{Na}]^{+}\right): 300.1370$; Found: 300.1375 .

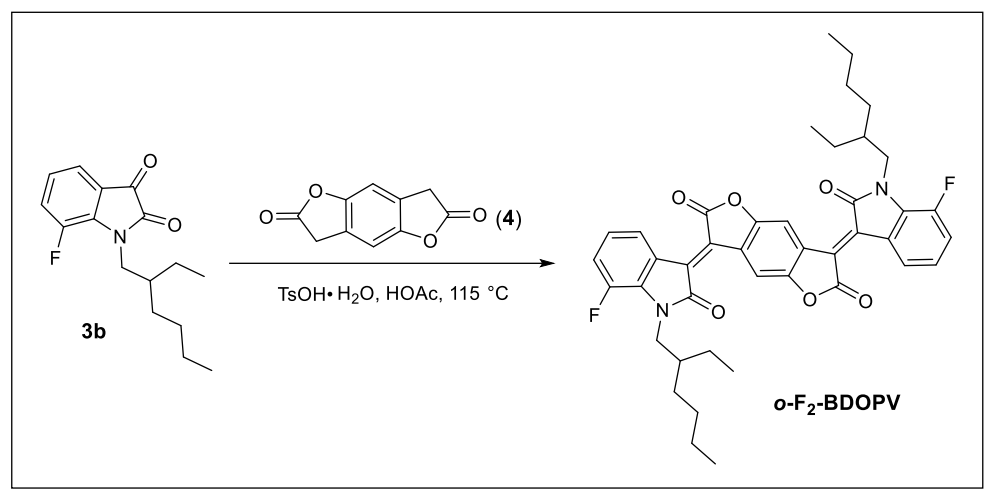

$\boldsymbol{o}$-F2-BDOPV: To a solution of 7-F-Isatin-EH (3b, $415 \mathrm{mg}, 1.5 \mathrm{mmol})$ in acetic acid (25 mL), 4 (143 mg, $0.75 \mathrm{mmol}$ ) and toluenesulfonic acid monohydrate (38 mg, $0.20 \mathrm{mmol}$ ) was added. The mixture was stirred at $115{ }^{\circ} \mathrm{C}$ under nitrogen atmosphere for $17 \mathrm{~h}$, and then cooled to room temperature and filtered. After washed with acetic acid and methanol, the filtration residues were dissolved in $\mathrm{CHCl}_{3}(100 \mathrm{~mL})$ and then washed with water and brine, and dried over with $\mathrm{Na}_{2} \mathrm{SO}_{4}$. After removal of the solvents under reduced pressure, the residue was purified by silica gel chromatography with eluent $\left(\mathrm{PE}: \mathrm{CH}_{2} \mathrm{Cl}_{2}=2: 1\right)$ to give a black solid. Reaction Yield: 52\%. ${ }^{1} \mathrm{H} \mathrm{NMR}\left(\mathrm{CDCl}_{3}, 500 \mathrm{MHz}, \mathrm{ppm}\right): \delta 9.08(\mathrm{~s}, 2 \mathrm{H}), 8.88-8.86(\mathrm{~d}, J=8.4$, 2H), 7.17-7.12 (dd, $\left.J_{1}=11.6 \mathrm{~Hz}, J_{2}=8.6 \mathrm{~Hz}, 2 \mathrm{H}\right), 7.03-6.97(\mathrm{~m}, 2 \mathrm{H}), 3.89-3.79(\mathrm{~m}, 4 \mathrm{H})$, $1.83(\mathrm{~m}, 2 \mathrm{H}), 1.54-1.22(\mathrm{~m}, 16 \mathrm{H}), 0.95-0.87$ (m, 12H). ${ }^{13} \mathrm{C} \mathrm{NMR}\left(\mathrm{CDCl}_{3}, 125 \mathrm{MHz}, \mathrm{ppm}\right)$ : $\delta 166.90,166.73,151.78,148.17,145.75,136.35,136.31,132.83,132.74,127.38,126.98$, $126.40,126.37,123.61,123.58,122.83,122.77,122.12,121.92,111.14,46.33,46.29,38.86$, $38.83,30.43,28.48,23.75,23.04,14.03,10.55$. Elemental Anal. calcd. for $\mathrm{C}_{42} \mathrm{H}_{42} \mathrm{~F}_{2} \mathrm{~N}_{2} \mathrm{O}_{6}$ : C, 71.17; H, 5.97; N, 3.95; Found: C, 71.08; H, 6.09; N, 3.78. ESI-HRMS calcd. for $\mathrm{C}_{42} \mathrm{H}_{43} \mathrm{~F}_{2} \mathrm{~N}_{2} \mathrm{O}_{6}\left([\mathrm{M}+\mathrm{H}]^{+}\right)$: 709.3084; Found: 709.3100 .

\section{Synthesis of $p-F_{2}-B D O P V$}




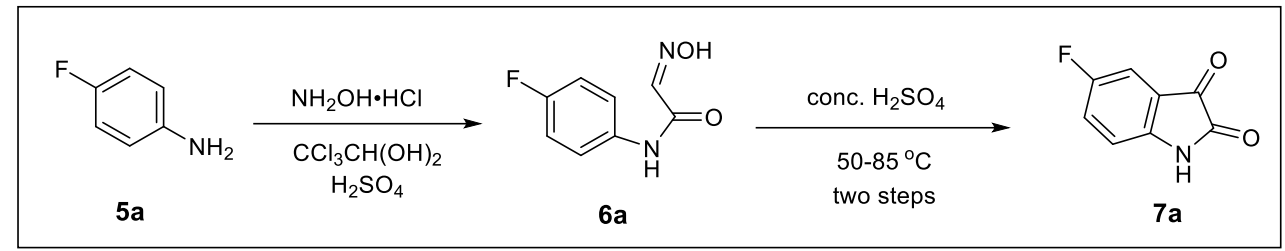

5-F-Isatin (7a): To a solution of chloral hydrate $(16.5 \mathrm{~g}, 100 \mathrm{mmol})$ in deionized water (300 mL), $\mathrm{Na}_{2} \mathrm{SO}_{4}$ (145 g, $1.02 \mathrm{~mol}$ ), 4-fluoroaniline (5a, $\left.8.6 \mathrm{~g}, 77.5 \mathrm{mmol}\right), \mathrm{H}_{2} \mathrm{SO}_{4}(80 \mathrm{~mL}, 1 \mathrm{M})$ and hydroxylamine hydrochloride $(16.2 \mathrm{~g}, 233 \mathrm{mmol})$ was added. The mixture was heated to $130{ }^{\circ} \mathrm{C}$ and refluxed for $30 \mathrm{~min}$. The mixture was then cooled to $80{ }^{\circ} \mathrm{C}$ and filtered to collect the product. The product was washed with deionized water and dried in vacuum to afford $\mathbf{6 a}$ as a gray-white solid, which was directly used for the next step without further purification.

To a concentrated $\mathrm{H}_{2} \mathrm{SO}_{4}(300 \mathrm{~mL})$ in $500 \mathrm{~mL}$ round-bottom flask kept at $50{ }^{\circ} \mathrm{C}$, compound 6a was added portionwise with stirring. The mixture was heated to $85^{\circ} \mathrm{C}$ for $3 \mathrm{~h}$ before pouring into ice water. The precipitate was collected by filtration and the filtrate was extract with ethyl acetate (EA). The precipitate and the extraction were combined and subject to column chromatography (silica gel; eluent: petroleum ester $(\mathrm{PE}): \mathrm{EA}=8: 1$ ) to afforded $\mathbf{7 a}$ as an orange solid. Reaction Yield: 55\%. ${ }^{1} \mathrm{H}$ NMR (DMSO-d $\left.6,500 \mathrm{MHz}, \mathrm{ppm}\right): \delta 11.02(\mathrm{~s}, 1 \mathrm{H}$ ), $7.47-7.43(\mathrm{~m}, 1 \mathrm{H}), 7.40-7.38\left(\mathrm{dd}, J_{1}=7.2 \mathrm{~Hz}, J_{2}=2.7 \mathrm{~Hz}, 1 \mathrm{H}\right), 6.93-6.91\left(\mathrm{dd}, J_{1}=8.6 \mathrm{~Hz}\right.$, $\left.J_{2}=3.9 \mathrm{~Hz}, 1 \mathrm{H}\right),{ }^{13} \mathrm{C}$ NMR (DMSO-d $\left.6,125 \mathrm{MHz}, \mathrm{ppm}\right): \delta 183.85,183.83,159.41,159.00$, $157.09,146.94,146.93,124.56,124.36,118.48,118.43,113.46,113.40,111.42,111.23$. ESIHRMS calcd. for $\mathrm{C}_{8} \mathrm{H}_{5} \mathrm{FNO}_{2}\left([\mathrm{M}+\mathrm{H}]^{+}\right)$: 166.0299; Found: 166.0300.

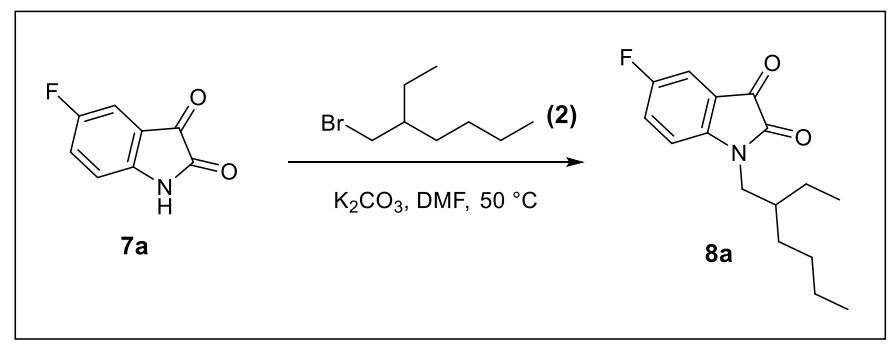

5-F-Isatin-EH (8a): To a solution of the 3-(bromomethyl)heptane (2, $1.12 \mathrm{~g}, 6.0 \mathrm{mmol})$ in $N, N$ '-dimethylformamide (DMF) $(30 \mathrm{~mL}), 5$-F-Isatin $(7 \mathbf{a}, 0.83 \mathrm{~g}, 5.0 \mathrm{mmol})$, and $\mathrm{K}_{2} \mathrm{CO}_{3}$ 
$(1.04 \mathrm{~g}, 7.5 \mathrm{mmol})$ was added. The mixture was stirred at $50{ }^{\circ} \mathrm{C}$ for $12 \mathrm{~h}$ and then the solvents were removed under reduced pressure. The residues were dissolved in $\mathrm{CHCl}_{3}(100 \mathrm{~mL})$ and then washed with water and brine, and dried over with $\mathrm{Na}_{2} \mathrm{SO}_{4}$. After removal of the solvents under reduced pressure, the residue was purified by silica gel chromatography with eluent (PE: $\left.\mathrm{CH}_{2} \mathrm{Cl}_{2}=2: 1\right)$ to give an orange solid. Reaction Yield: $68 \% .{ }^{1} \mathrm{H} \mathrm{NMR}\left(\mathrm{CDCl}_{3}, 500 \mathrm{MHz}\right.$, ppm): $\delta 7.31-7.27(\mathrm{~m}, 2 \mathrm{H}), 6.85-6.83\left(\mathrm{dd}, J_{1}=8.3 \mathrm{~Hz}, J_{2}=3.4 \mathrm{~Hz}, 1 \mathrm{H}\right), 3.65-3.56(\mathrm{~m}, 2 \mathrm{H})$, $1.83-1.76(\mathrm{~m}, 1 \mathrm{H}), 1.43-1.22(\mathrm{~m}, 8 \mathrm{H}), 0.95-0.83(\mathrm{~m}, 6 \mathrm{H}) .{ }^{13} \mathrm{C} \mathrm{NMR}\left(\mathrm{CDCl}_{3}, 100 \mathrm{MHz}, \mathrm{ppm}\right)$ : $\delta 182.99,182.96,160.36,158.18,158.17,157.92,147.44,147.42,124.65,124.41,118.16$, $118.09,112.45,112.21,111.51,111.44,44.40,37.19,30.49,28.51,23.85,22.93,13.96,10.46$. ESI-HRMS calcd. for $\mathrm{C}_{16} \mathrm{H}_{21} \mathrm{FNO}_{2}\left([\mathrm{M}+\mathrm{H}]^{+}\right)$: 278.1551; Found: 278.1552 .

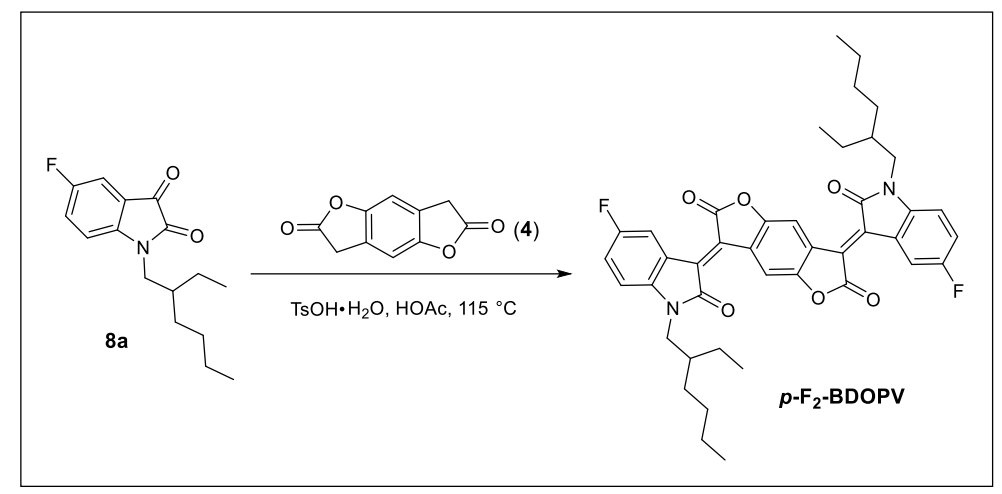

p-F2-BDOPV: To a solution of 5-F-Isatin-EH (8a, $415 \mathrm{mg}, 1.5 \mathrm{mmol})$ in acetic acid (25 mL), 4 (143 mg, $0.75 \mathrm{mmol}$ ) and toluenesulfonic acid monohydrate (38 mg, $0.20 \mathrm{mmol})$ was added. The mixture was stirred at $115{ }^{\circ} \mathrm{C}$ under nitrogen atmosphere for $17 \mathrm{~h}$, and then cooled to room temperature and filtered. After washed with acetic acid and methanol, the filtration residues were dissolved in $\mathrm{CHCl}_{3}(100 \mathrm{~mL})$ and then washed with water and brine, and dried over with $\mathrm{Na}_{2} \mathrm{SO}_{4}$. After removal of the solvents under reduced pressure, the residue was purified by silica gel chromatography with eluent $\left(\mathrm{PE}: \mathrm{CH}_{2} \mathrm{Cl}_{2}=2: 1\right)$ to give a black solid. Reaction Yield: $46 \% .{ }^{1} \mathrm{H}$ NMR $\left(\mathrm{CDCl}_{3}, 400 \mathrm{MHz}, \mathrm{ppm}\right): \delta 9.00(\mathrm{~s}, 2 \mathrm{H}), 8.73-8.69$ (dd, $J_{1}=$ $\left.10.5, J_{2}=2.6 \mathrm{~Hz}, 2 \mathrm{H}\right), 7.01-6.96(\mathrm{~m}, 2 \mathrm{H}), 6.62-6.59\left(\mathrm{dd}, J_{1}=8.6 \mathrm{~Hz}, J_{2}=4.4 \mathrm{~Hz}, 2 \mathrm{H}\right)$, $3.67-3.49(\mathrm{~m}, 4 \mathrm{H}), 1.82-1.79(\mathrm{~m}, 2 \mathrm{H}), 1.44-1.32(\mathrm{~m}, 16 \mathrm{H}), 0.98-0.90(\mathrm{~m}, 12 \mathrm{H}) .{ }^{13} \mathrm{C} \mathrm{NMR}$ 
$\left(\mathrm{CDCl}_{3}, 125 \mathrm{MHz}, \mathrm{ppm}\right): \delta 167.16,166.91,159.44,157.54,151.99,142.69,136.55,136.52$, $127.30,126.89,121.62,121.54,120.68,120.48,117.79,117.57,111.33,108.89,108.83$, $44.51,37.53,30.72,28.69,34.11,23.03,14.03,10.66$. Elemental Anal. calcd. for $\mathrm{C}_{42} \mathrm{H}_{42} \mathrm{~F}_{2} \mathrm{~N}_{2} \mathrm{O}_{6}: \mathrm{C}, 71.17 ; \mathrm{H}, 5.97 ; \mathrm{N}, 3.95$; Found: C, 71.16; H, 5.92; N, 3.96. ESI-HRMS calcd. for $\mathrm{C}_{42} \mathrm{H}_{43} \mathrm{~F}_{2} \mathrm{~N}_{2} \mathrm{O}_{6}\left([\mathrm{M}+\mathrm{H}]^{+}\right)$: 709.3084; Found: 709.3104 .

\section{Synthesis of F-BDOPV}

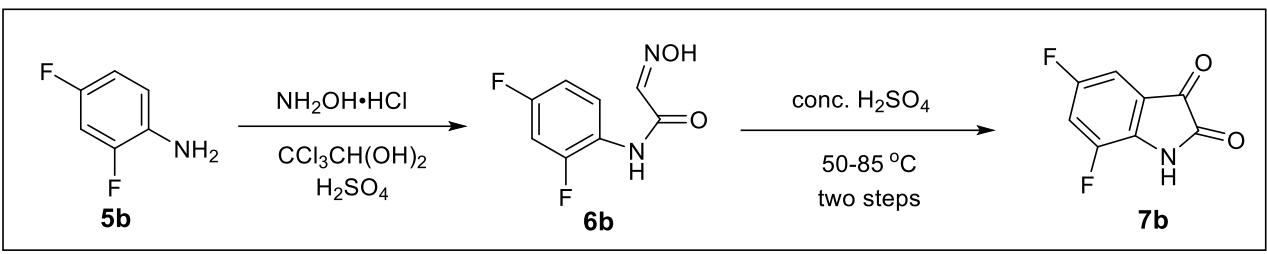

F2-Isatin (7b): To a solution of chloral hydrate (16.5 g, $100 \mathrm{mmol})$ in deionized water (300 $\mathrm{mL}), \mathrm{Na}_{2} \mathrm{SO}_{4}$ (145 g, $\left.1.02 \mathrm{~mol}\right)$, , 24-difluoroaniline (10.0 g, $\left.77.5 \mathrm{mmol}\right), \mathrm{H}_{2} \mathrm{SO}_{4}(80 \mathrm{~mL}, 1 \mathrm{M})$ and hydroxylamine hydrochloride $(16.2 \mathrm{~g}, 233 \mathrm{mmol})$ were added. The mixture was heated to $130{ }^{\circ} \mathrm{C}$ and refluxed for $30 \mathrm{~min}$. The mixture was then cooled to $80{ }^{\circ} \mathrm{C}$ and filtered to collect the product. The product was washed with deionized water and dried in vacuum to afford $\mathbf{6 b}$ as a gray-white solid, which was directly used for the next step without further purification.

To a concentrated $\mathrm{H}_{2} \mathrm{SO}_{4}(300 \mathrm{~mL})$ in $500 \mathrm{~mL}$ round-bottom flask kept at $50{ }^{\circ} \mathrm{C}$, compound 6b was added portionwise with stirring. The mixture was heated to $85^{\circ} \mathrm{C}$ for $3 \mathrm{~h}$ before pouring into ice water. The precipitate was collected by filtration and the filtrate was extract with EA. The precipitate and the extraction were combined and subject to column chromatography (silica gel; eluent: $\mathrm{PE}: \mathrm{EA}=8: 1$ ) to afforded $\mathbf{7 b}$ as orange solids. Reaction Yield: $11 \% .{ }^{1} \mathrm{H}$ NMR (DMSO-d $\left.6,400 \mathrm{MHz}, \mathrm{ppm}\right): \delta 11.55(\mathrm{~s}, 1 \mathrm{H}), 7.68-7.62(\mathrm{~m}, 1 \mathrm{H}), 7.36-$ $7.33\left(\mathrm{dd}, J_{1}=6.7 \mathrm{~Hz}, J_{2}=3.9 \mathrm{~Hz}, 1 \mathrm{H}\right) .{ }^{13} \mathrm{C} \mathrm{NMR}\left(\mathrm{DMSO}_{6}, 100 \mathrm{MHz}, \mathrm{ppm}\right): \delta 182.62$, $182.59,182.57,182.55,159.30,159.29,158.77,158.68,156.4,156.3,148.2,145.8,145.7$, $134.42,134.39,134.3,120.4,120.30,120.27,120.2,113.0,112.8,112.7,112.5,108.0,107.9$, 107.71, 107.67. ESI-HRMS calcd. for $\mathrm{C}_{8} \mathrm{H}_{7} \mathrm{~F}_{2} \mathrm{~N}_{2} \mathrm{O}_{2}\left(\left[\mathrm{M}+\mathrm{NH}_{4}\right]^{+}\right)$: 201.0470; Found: 
201.0464 .

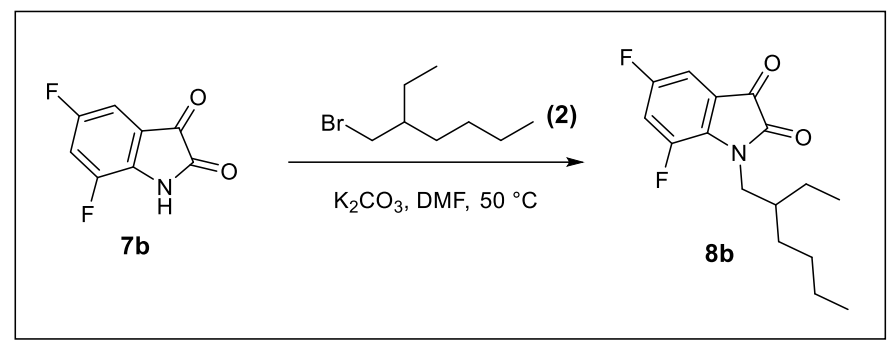

F2-Isatin-EH (8b): To a solution of the 3-(bromomethyl)heptane (2, $1.12 \mathrm{~g}, 6.0 \mathrm{mmol})$ in $N, N^{\prime}$-dimethylformamide (DMF) $(30 \mathrm{~mL}), \mathrm{F}_{2}$-Isatin $(7 \mathbf{b}, 0.83 \mathrm{~g}, 5.0 \mathrm{mmol})$, and $\mathrm{K}_{2} \mathrm{CO}_{3}(1.04$ g, $7.5 \mathrm{mmol}$ ) were added. The mixture was stirred at $50{ }^{\circ} \mathrm{C}$ for $12 \mathrm{~h}$ and then the solvents were removed under reduced pressure. The residue was dissolved in $\mathrm{CHCl}_{3}(100 \mathrm{~mL})$ and then washed with water and brine, and dried over with $\mathrm{Na}_{2} \mathrm{SO}_{4}$. After removal of the solvents under reduced pressure, the residue was purified by silica gel chromatography with eluent (PE: $\left.\mathrm{CH}_{2} \mathrm{Cl}_{2}=2: 1\right)$ to give orange solids. Reaction Yield: $75 \% .{ }^{1} \mathrm{H} \mathrm{NMR}\left(\mathrm{CDCl}_{3}, 500 \mathrm{MHz}\right.$, ppm): $\delta 7.20-7.18\left(\mathrm{dd}, J_{1}=5.9 \mathrm{~Hz}, J_{2}=2.4 \mathrm{~Hz}, 1 \mathrm{H}\right), 7.14-7.10(\mathrm{~m}, 1 \mathrm{H}), 3.78-3.70(\mathrm{~m}, 2 \mathrm{H})$, $1.78-1.70(\mathrm{~m}, 1 \mathrm{H}), 1.40-1.24(\mathrm{~m}, 8 \mathrm{H}), 0.93-0.87(\mathrm{~m}, 6 \mathrm{H}) .{ }^{13} \mathrm{C} \mathrm{NMR}\left(\mathrm{CDCl}_{3}, 125 \mathrm{MHz}, \mathrm{ppm}\right)$ : $\delta 182.09,182.07,182.0,159.6,159.5,157.90,157.89,157.62,157.55,148.7,148.6,146.7$, 146.6, 133.99, 133.96, 133.92, 133.89, 120.18, 120.15, 120.12, 120.09, 114.1, 113.95, 113.92, $113.7,108.82,108.79,108.63,108.60,46.63,46.60,38.52,38.50,30.3,28.4,23.6,23.0,14.0$, 10.4. ESI-HRMS calcd. for $\mathrm{C}_{16} \mathrm{H}_{20} \mathrm{~F}_{2} \mathrm{NO}_{2}\left([\mathrm{M}+\mathrm{H}]^{+}\right)$: 296.1457; Found: 296.1462 .

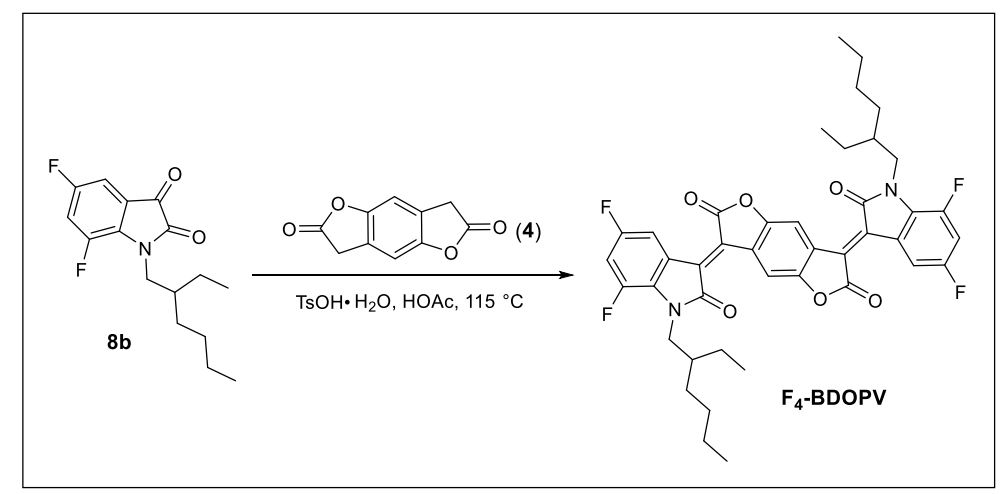

F4-BDOPV: To a solution of $\mathbf{8 b}(443 \mathrm{mg}, 1.5 \mathrm{mmol})$ in acetic acid $(25 \mathrm{~mL}), \mathbf{4}(0.75 \mathrm{mmol}$, $140 \mathrm{mg})$ and toluenesulfonic acid monohydrate $(0.20 \mathrm{mmol}, 38 \mathrm{mg})$ were added. The mixture 
was stirred at $115{ }^{\circ} \mathrm{C}$ under nitrogen atmosphere for $17 \mathrm{~h}$, and then cooled to room temperature and filtered. After washed with acetic acid and methanol, the residue was dissolved in $\mathrm{CHCl}_{3}(100 \mathrm{~mL})$ and then washed with water and brine, and dried over with $\mathrm{Na}_{2} \mathrm{SO}_{4}$. After removal of the solvents under reduced pressure, the residue was purified by silica gel chromatography with eluent $\left(\mathrm{PE}: \mathrm{CH}_{2} \mathrm{Cl}_{2}=2: 1\right)$ to give black solids. Reaction Yield: $85 \% .{ }^{1} \mathrm{H} \mathrm{NMR}\left(\mathrm{CDCl}_{3}, 400 \mathrm{MHz}, \mathrm{ppm}\right): \delta 9.14(\mathrm{~s}, 2 \mathrm{H}), 8.79-8.76\left(\mathrm{dd}, J_{1}=9.8 \mathrm{~Hz}, J_{2}=2.0\right.$ $\mathrm{Hz}, 2 \mathrm{H}), 7.00-6.95(\mathrm{~m}, 2 \mathrm{H}), 3.84-3.81(\mathrm{~m}, 4 \mathrm{H}), 1.81(\mathrm{~s}, 2 \mathrm{H}), 1.41-1.25(\mathrm{~m}, 16 \mathrm{H}), 0.95-0.87$ (m, 12H), ${ }^{13} \mathrm{C} \mathrm{NMR}\left(\mathrm{CDCl}_{3}, 125 \mathrm{MHz}, \mathrm{ppm}\right): \delta 166.7,166.6,158.6,158.5,156.7,156.6$, $152.2,147.3,147.2145 .34,145.25,136.1,129.48,129.46,129.41,128.5,127.1,123.34$, $123.30,123.26,123.22,113.84,113.81,113.62,113.59,111.6,110.2,109.99,109.96,109.8$, 46.39, 46.36, 38.84, 38.82, 30.5, 29.7, 28.5, 23.8, 23.0, 14.0, 10.6. Elemental Anal. calcd. for $\mathrm{C}_{42} \mathrm{H}_{40} \mathrm{~F}_{4} \mathrm{~N}_{2} \mathrm{O}_{6}$ : C, 67.73; H, 5.41; N, 3.76; Found: C, 67.78; H, 5.45; N, 3.68. ESI-HRMS calcd. for $\mathrm{C}_{42} \mathrm{H}_{41} \mathrm{~F}_{4} \mathrm{~N}_{2} \mathrm{O}_{6}\left([\mathrm{M}+\mathrm{H}]^{+}\right)$: 745.2895; Found: 745.2893.

\section{E. Synthesis of F6-BDOPV}

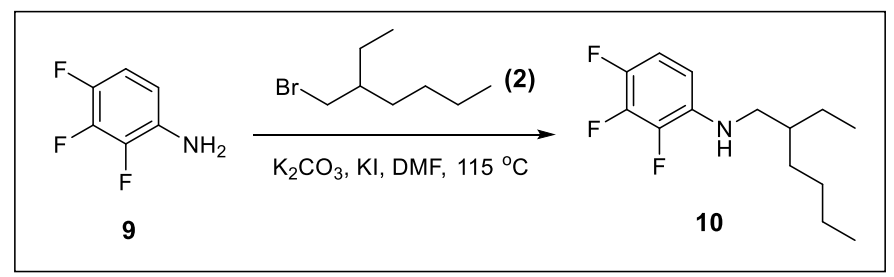

N-(2-ethylhexyl)-2,3,4-trifluoroaniline (10): To a solution of the 3-(bromomethyl)heptane (2, $15.1 \mathrm{~g}, 78.2 \mathrm{mmol}), \mathrm{K}_{2} \mathrm{CO}_{3}(12.2 \mathrm{~g}, 102.0 \mathrm{mmol})$ and $\mathrm{KI}(11.3 \mathrm{~g}, 68.0 \mathrm{mmol})$ in $N, N^{\prime}-$ dimethylformamide (DMF) (15 mL), the 2,3,4-trifluoroaniline $(9,10.0 \mathrm{~g}, 68.0 \mathrm{mmol})$ was added. The mixture was stirred under nitrogen atmosphere at $115^{\circ} \mathrm{C}$ for $16 \mathrm{~h}$. Then the solution was diluted with water and extracted with ethyl acetate. The aqueous layer was extracted with ethyl acetate and the organic layers were combined, dried with $\mathrm{Na}_{2} \mathrm{SO}_{4}$, filtered, and the solvents were removed under reduced pressure. After that, the residue was purified by silica gel chromatography with eluent (PE) to give a light yellow liquid. Reaction 
Yield: 54\%. ${ }^{1} \mathrm{H} \mathrm{NMR}\left(\mathrm{CDCl}_{3}, 400 \mathrm{MHz}, \mathrm{ppm}\right): \delta 6.84-6.77(\mathrm{~m}, 1 \mathrm{H}), 6.35-6.30(\mathrm{~m}, 1 \mathrm{H})$, $3.73(\mathrm{~s}, 1 \mathrm{H}), 3.03-3.00(\mathrm{t}, 2 \mathrm{H}), 1.60-1.52(\mathrm{~m}, 1 \mathrm{H}), 1.46-1.27(\mathrm{~m}, 8 \mathrm{H}), 0.93-0.87(\mathrm{~m}, 6 \mathrm{H})$. ${ }^{13} \mathrm{C}$ NMR $\left(\mathrm{CDCl}_{3}, 100 \mathrm{MHz}, \mathrm{ppm}\right): \delta 144.10,144.08,144.00,143.98,141.74,141.72$, $141.64,141.61,141.55,141.48,141.45,141.42,141.38,141.34,141.25,139.09,139.06$, $138.96,138.79,134.89,134.81,111.06,111.03,110.89,110.85,104.58,104.54,104.51$, 104.47, 104.44, 46.98, 39.02, 31.16, 28.92, 24.36, 23.03, 14.01, 10.82. ESI-HRMS calcd. for $\mathrm{C}_{14} \mathrm{H}_{21} \mathrm{~F}_{3} \mathrm{~N}\left([\mathrm{M}+\mathrm{H}]^{+}\right): 260.1621$; Found: 260.1621 .

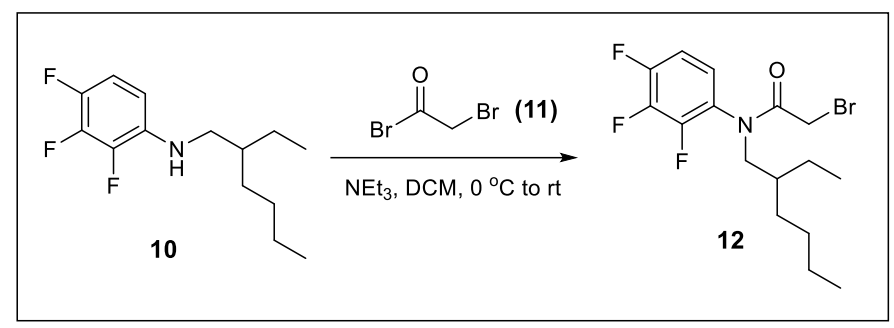

2-bromo-N-(2-ethylhexyl)-N-(2,3,4-trifluorophenyl)acetamide (12): To a solution of N-(2ethylhexyl)-2,3,4-trifluoroaniline $(\mathbf{1 0}, 2.6 \mathrm{~g}, 10.0 \mathrm{mmol})$ and $\mathrm{NEt}_{3}(2.0 \mathrm{~g}, 20.0 \mathrm{mmol})$ in $\mathrm{CH}_{2} \mathrm{Cl}_{2}(30 \mathrm{ml})$ at $0{ }^{\circ} \mathrm{C}$ was added bromoacetyl bromide $(\mathbf{1 1}, 3.6 \mathrm{~g}, 18.0 \mathrm{mmol})$ slowly. The reaction was warmed to room temperature and stirred under nitrogen atmosphere for $3 \mathrm{~h}$. The reaction mixture was quenched with saturated aqueous $\mathrm{NH}_{4} \mathrm{Cl}(20 \mathrm{ml})$ and then was extracted with $\mathrm{CH}_{2} \mathrm{Cl}_{2}$. The organic layers were combined, dried with $\mathrm{Na}_{2} \mathrm{SO}_{4}$, filtered, and the solvents were removed under reduced pressure. After that, the residue was purified by silica gel chromatography with eluent $(\mathrm{PE}: \mathrm{EA}=98: 2)$ to give an orange liquid. Repeat this step for several times to accumulate the compound 12. Reaction Yield: $98 \% .{ }^{1} \mathrm{H}$ NMR $\left(\mathrm{CDCl}_{3}, 400\right.$ $\mathrm{MHz}, \mathrm{ppm}): \delta$ 7.17-7.06 (m, 2H), 3.87-3.73 and 3.53-3.40 (m, 2H), 3.71-3.56 (m, 2H), 3.02-2.99 (t, 2H), 1.40-1.15 (m, 9H), 0.89-0.80 (m, 6H). ${ }^{13} \mathrm{C} \mathrm{NMR}\left(\mathrm{CDCl}_{3}, 100 \mathrm{MHz}, \mathrm{ppm}\right)$ : $\delta 166.65,152.33,149.90,149.15,146.73,141.90,139.36,126.80,126.76,126.71,124.28$, $124.25,124.21,124.17,112.53,112.49,112.45,112.35,112.31,112.27,52.79,52.64,37.73$, $37.70,30.19,30.06,28.49,28.39,26.46,23.55,23.35,22.97,22.92,14.00,13.97,10.39$, 10.29. EI-TOF-MS calcd. for $\mathrm{C}_{16} \mathrm{H}_{21} \mathrm{BrF}_{3} \mathrm{NO}\left([\mathrm{M}]^{+}\right): 379: 381=1: 1$; Found: $379: 381=1: 1$. 


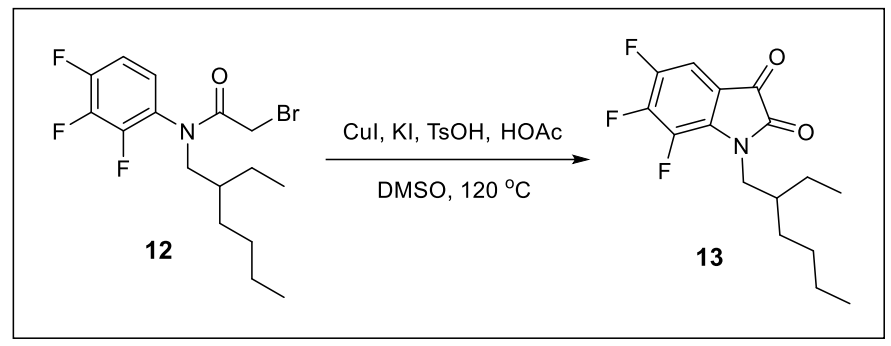

F3-Isatin-EH (13): To a stirred solution of DMSO (100 ml) was added CuI (1.9 g, 10.2 mmol), KI (1.7 g, $10.2 \mathrm{mmol})$, toluenesulfonic acid monohydrate (0.39 g, $2.0 \mathrm{mmol})$, HOAc (10.0 ml) and 2-bromo-N-(2-ethylhexyl)-N-(2,3,4-trifluorophenyl)acetamide (12, $7.7 \mathrm{~g}, 20.3$ mmol) at room temperature. The system was heated at $120^{\circ} \mathrm{C}$ for 48 hours (open to air with a pump pumping air continuously into the reaction mixture). After cooling to room temperature, the reaction mixture was diluted with EA and water. The aqueous layer was extracted with EA. The organic layers were combined, dried with $\mathrm{Na}_{2} \mathrm{SO}_{4}$, filtered, and the solvents were removed under reduced pressure. After that, the residue was purified by silica gel chromatography with eluent $(\mathrm{PE}: \mathrm{EA}=95: 5)$ to give a red liquid. Reaction Yield: $21 \% .{ }^{1} \mathrm{H}$ NMR ( $\left.\mathrm{CD}_{2} \mathrm{Cl}_{2}, 400 \mathrm{MHz}, \mathrm{ppm}\right): \delta 7.34-7.30(\mathrm{~m}, 1 \mathrm{H}), 3.75-3.65(\mathrm{~m}, 2 \mathrm{H}), 1.75(\mathrm{~m}, 1 \mathrm{H}), 1.38-$ $1.21(\mathrm{~m}, 8 \mathrm{H}), 0.91-0.84(\mathrm{~m}, 6 \mathrm{H}) .{ }^{13} \mathrm{C} \mathrm{NMR}\left(\mathrm{CD}_{2} \mathrm{Cl}_{2}, 100 \mathrm{MHz}, \mathrm{ppm}\right): \delta 181.25,158.23$, $158.21,149.26,149.15,148.98,148.84,148.82,148.67 \mathrm{~m} \mathrm{146.78,} \mathrm{146.66,} \mathrm{146.37,} \mathrm{146.22,}$ $146.20,146.06,139.84,139.69,137.31,137.29,137.16,137.15,136.11,136.09,136.06$, $136.03,113.47,113.44,113.43,113.40,113.38,113.37,113.34,110.30,110.29,110.26$, $110.25,110.10,110.09,110.07,110.06,54.38,54.11,53.84,53.57,53.30,46.97,46.93$, 39.07, 39.05, 38.87, 30.67, 30.11, 28.80, 23.98, 23.80, 23.41, 23.23, 14.17, 10.50. ESI-HRMS calcd. for $\mathrm{C}_{16} \mathrm{H}_{18} \mathrm{~F}_{3} \mathrm{NNaO}_{2}\left([\mathrm{M}+\mathrm{Na}]^{+}\right)$: 336.1182; Found: 336.1184 . 


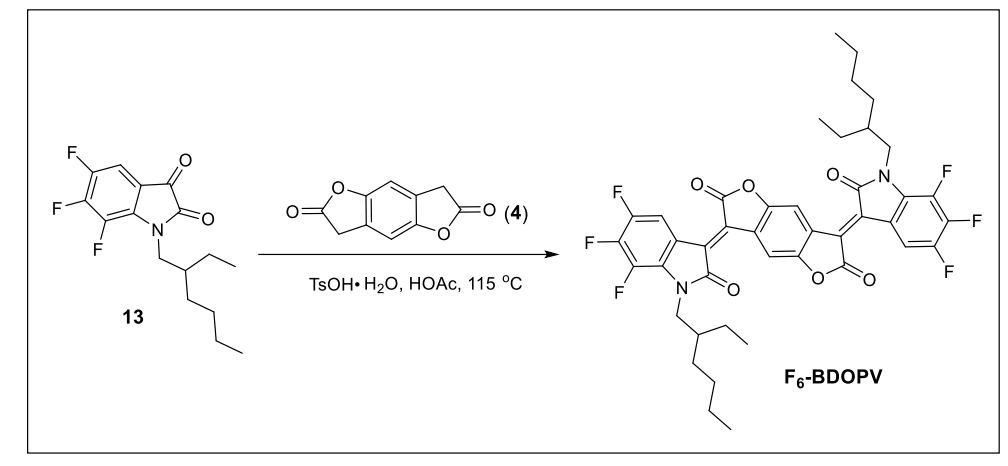

F6-BDOPV: To a solution of F-Isatin-EH (13) (925 mg, $3.0 \mathrm{mmol})$ in acetic acid (15 mL), 4 (255 mg, $1.3 \mathrm{mmol})$ and toluenesulfonic acid monohydrate $(71 \mathrm{mg}, 0.37 \mathrm{mmol})$ was added. The mixture was stirred at $115{ }^{\circ} \mathrm{C}$ under nitrogen atmosphere for $24 \mathrm{~h}$, and then cooled to room temperature and filtered. After washed with acetic acid and methanol, the filtration residues were dissolved in $\mathrm{CHCl}_{3}(100 \mathrm{~mL})$ and then washed with water and brine, and dried over with $\mathrm{Na}_{2} \mathrm{SO}_{4}$. After removal of the solvents under reduced pressure, the residue was purified by silica gel chromatography with eluent $\left(\mathrm{PE}: \mathrm{CHCl}_{3}=1: 4\right)$ to give a black solid. Reaction Yield: $75 \% .{ }^{1} \mathrm{H}$ NMR $\left(\mathrm{CDCl}_{3}, 500 \mathrm{MHz}, \mathrm{ppm}\right): \delta 8.98(\mathrm{~s}, 2 \mathrm{H}), 8.91-8.86\left(\mathrm{dd}, J_{1}=\right.$ $\left.11.6, J_{2}=7.9 \mathrm{~Hz}, 2 \mathrm{H}\right), 3.86-3.75(\mathrm{~m}, 4 \mathrm{H}), 1.79(\mathrm{~m}, 2 \mathrm{H}), 1.57-1.29(\mathrm{~m}, 16 \mathrm{H}), 0.96-0.89(\mathrm{~m}$, 12H). ${ }^{13} \mathrm{C} \mathrm{NMR}\left(\mathrm{CDCl}_{3}, 125 \mathrm{MHz}, \mathrm{ppm}\right): \delta 166.58,166.50,151.91,147.14,147.04,145.09$, $144.94,144.72,144.62,142.68,142.50,137.86,137.83,137.69,135.38,135.36,135.23$, $135.21,134.75,134.73,131.10,131.05,127.57,127.53,126.76,116.26,116.25,116.21$, $116.16,116.12,115.02,114.81,111.45,46.33,46.29,38.89,30.38,28.45,23.71,23.03$, 14.01, 10.48. Elemental Anal. calcd. for $\mathrm{C}_{42} \mathrm{H}_{38} \mathrm{~F}_{6} \mathrm{~N}_{2} \mathrm{O}_{6}$ : C, 64.61; H, 4.91; N, 3.59; Found: C, 64.72; H, 4.94; N, 3.44. ESI-HRMS calcd. for $\mathrm{C}_{42} \mathrm{H}_{39} \mathrm{~F}_{6} \mathrm{~N}_{2} \mathrm{O}_{6}\left([\mathrm{M}+\mathrm{H}]^{+}\right)$: 781.2707; Found: 781.2728

\section{References:}

1. Wood, J. H.; Cox, L. Org. Synth. 1946, 26, 24.

2. Yan, Z.; Sun, B.; Li, Y. Chem. Commun. 2013, 49, 3790. 


\section{7. ${ }^{1} \mathrm{H}$ and ${ }^{13} \mathrm{C}$ NMR spectra of new compounds}
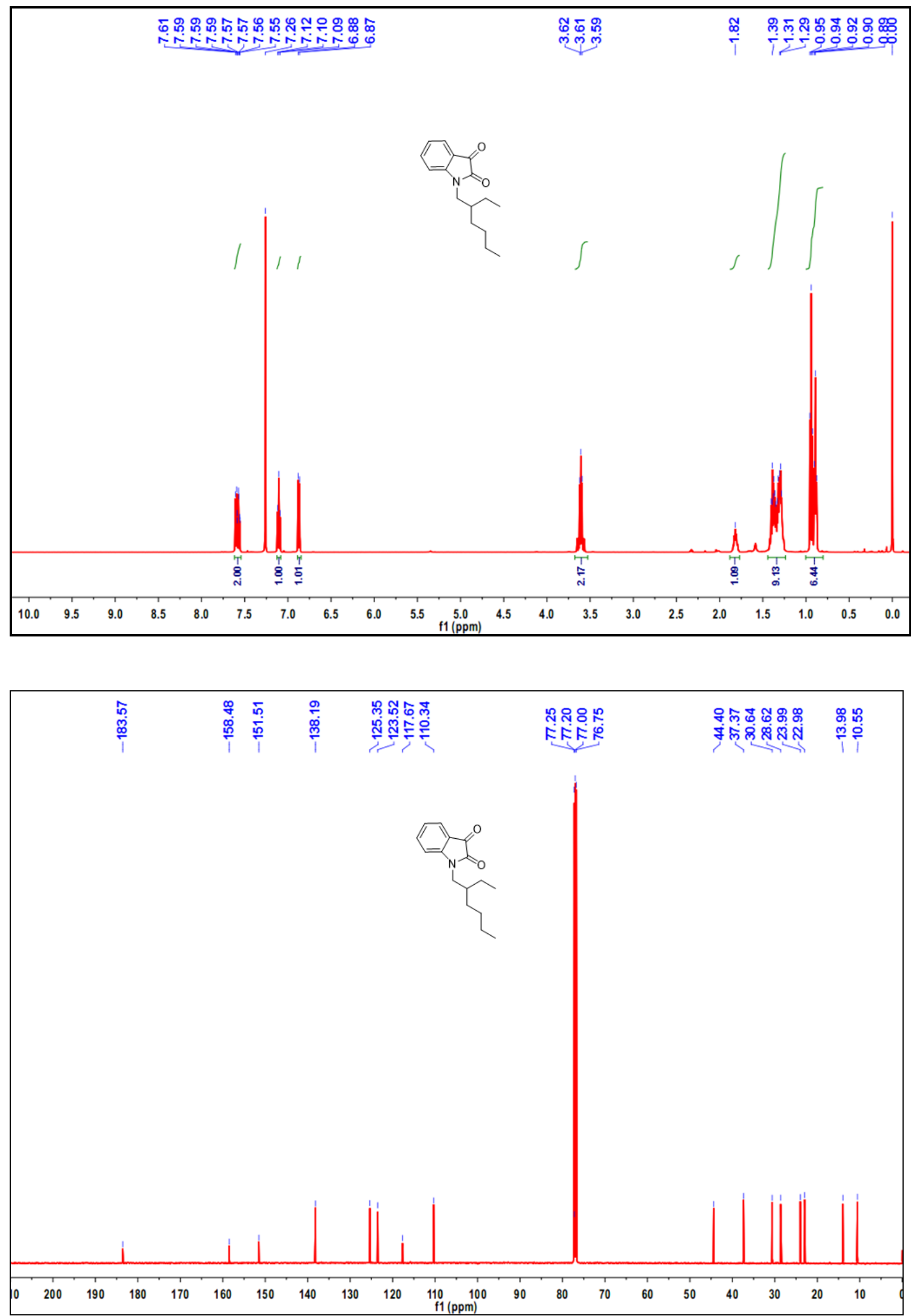

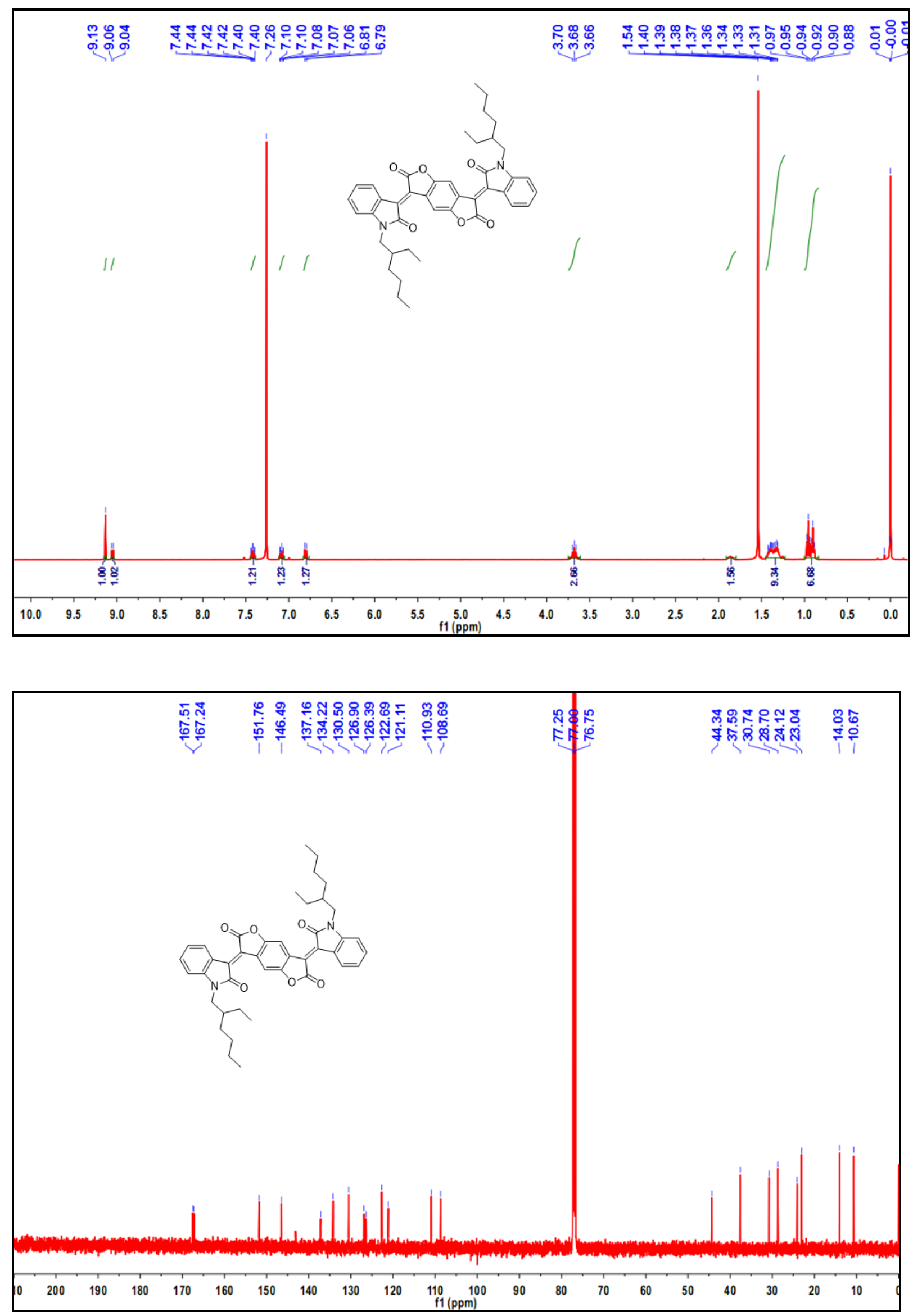

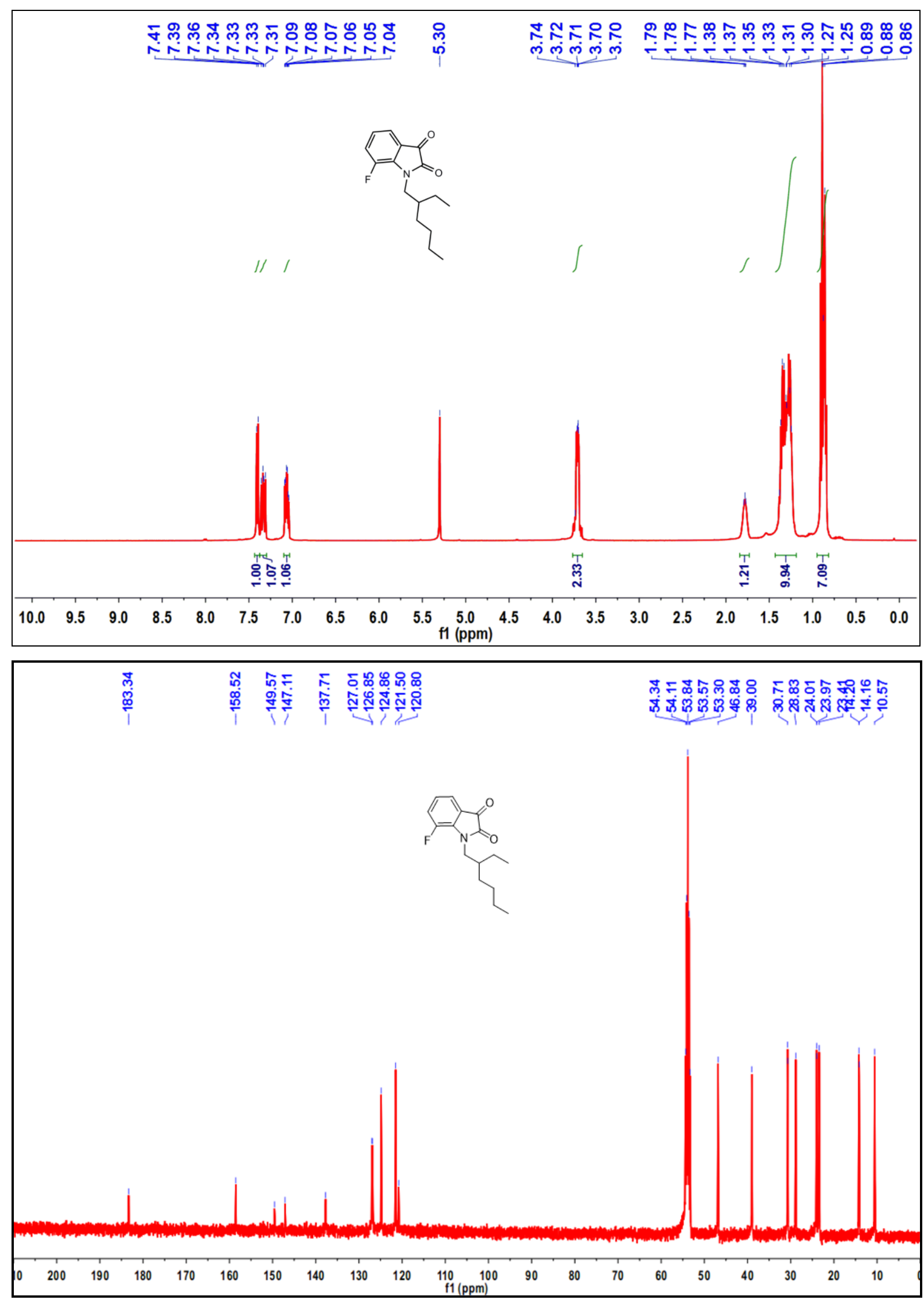

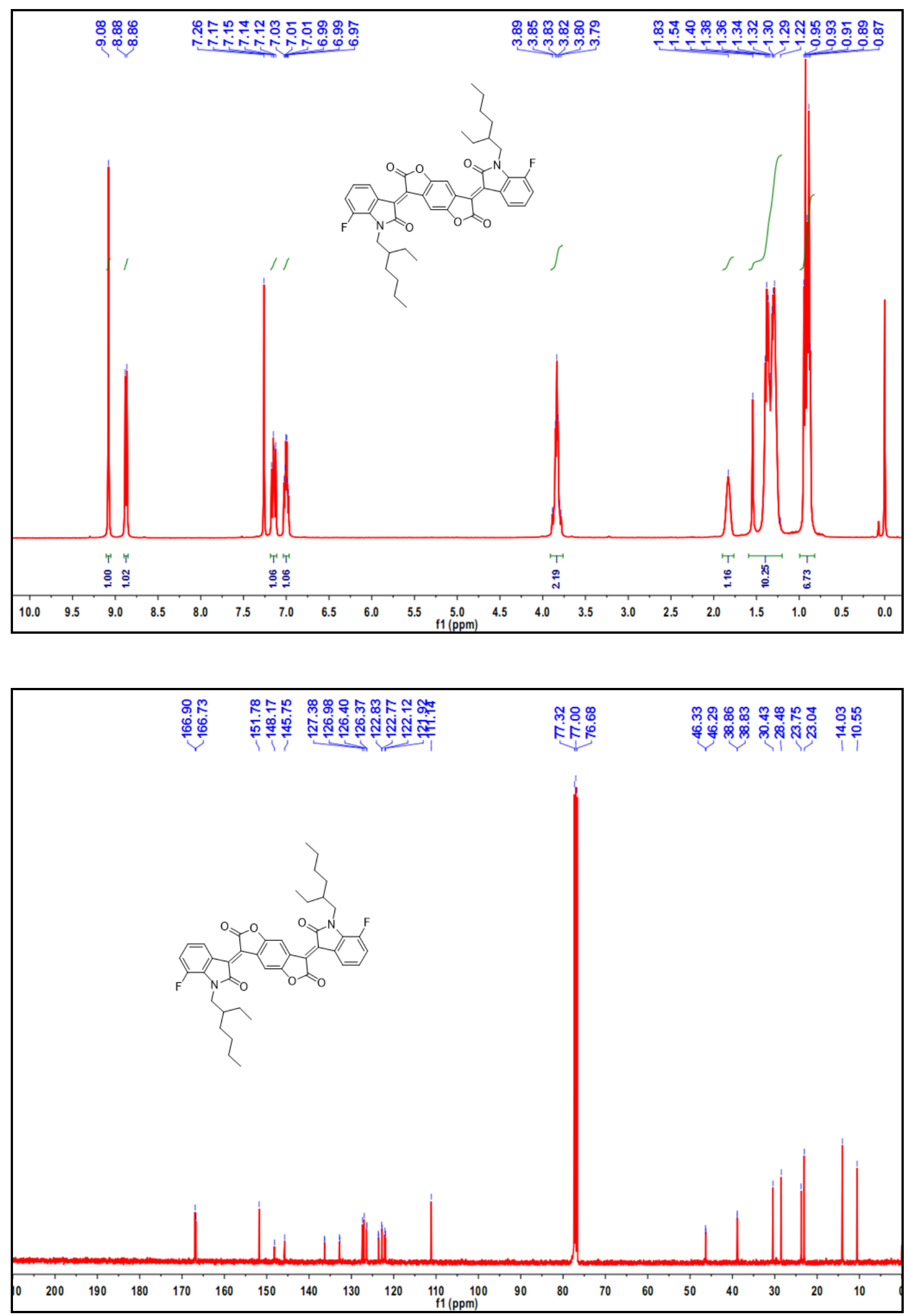

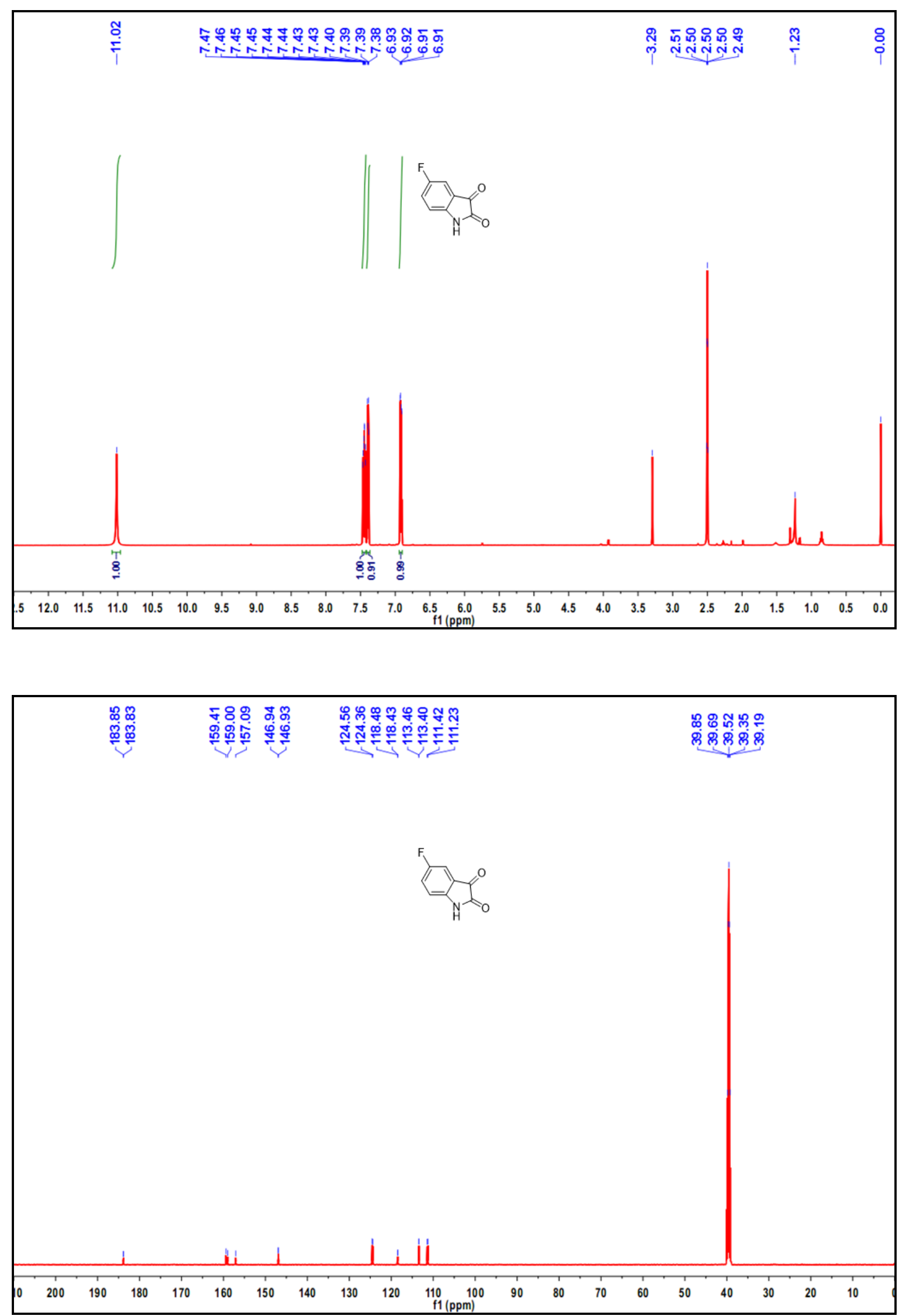

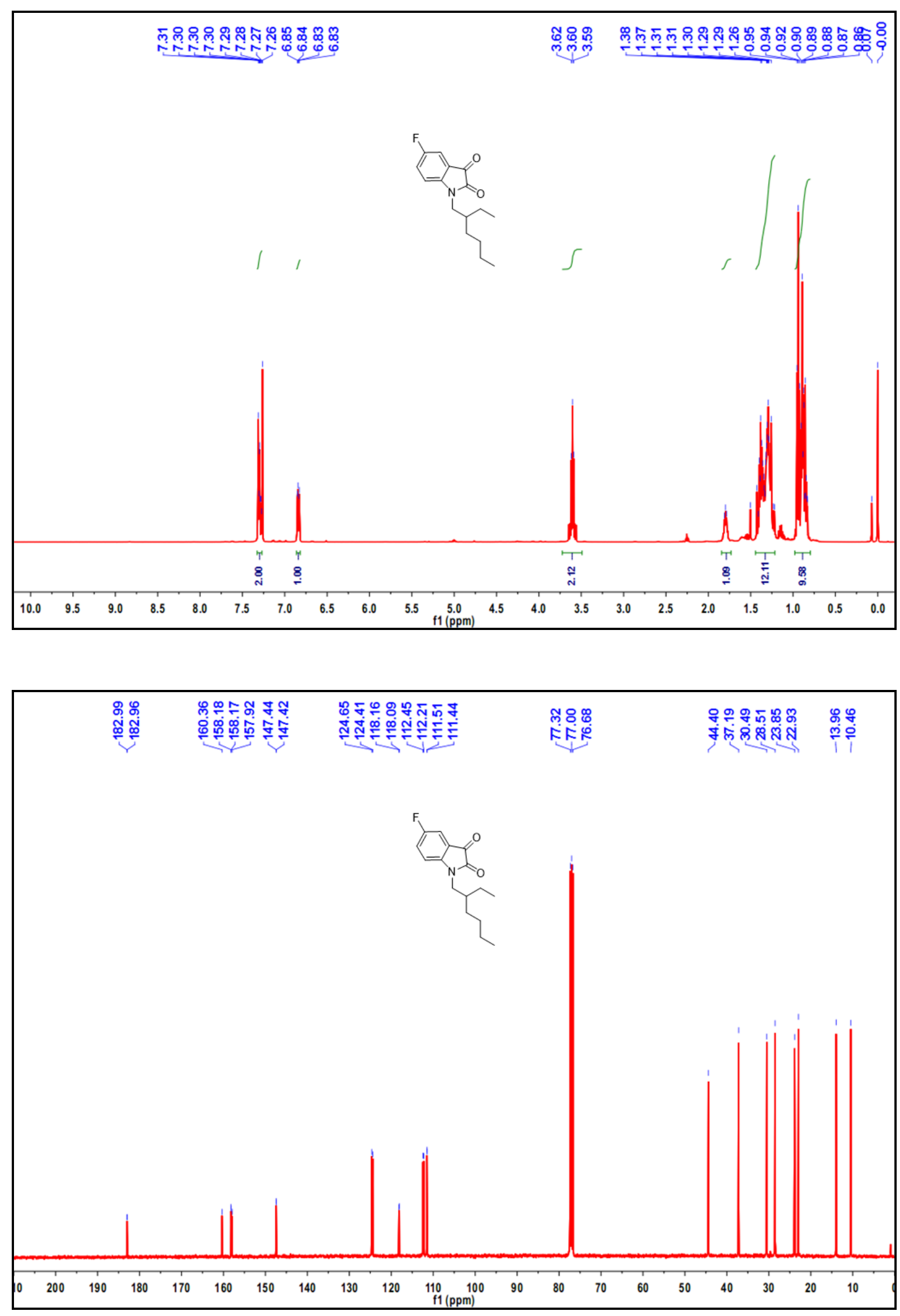

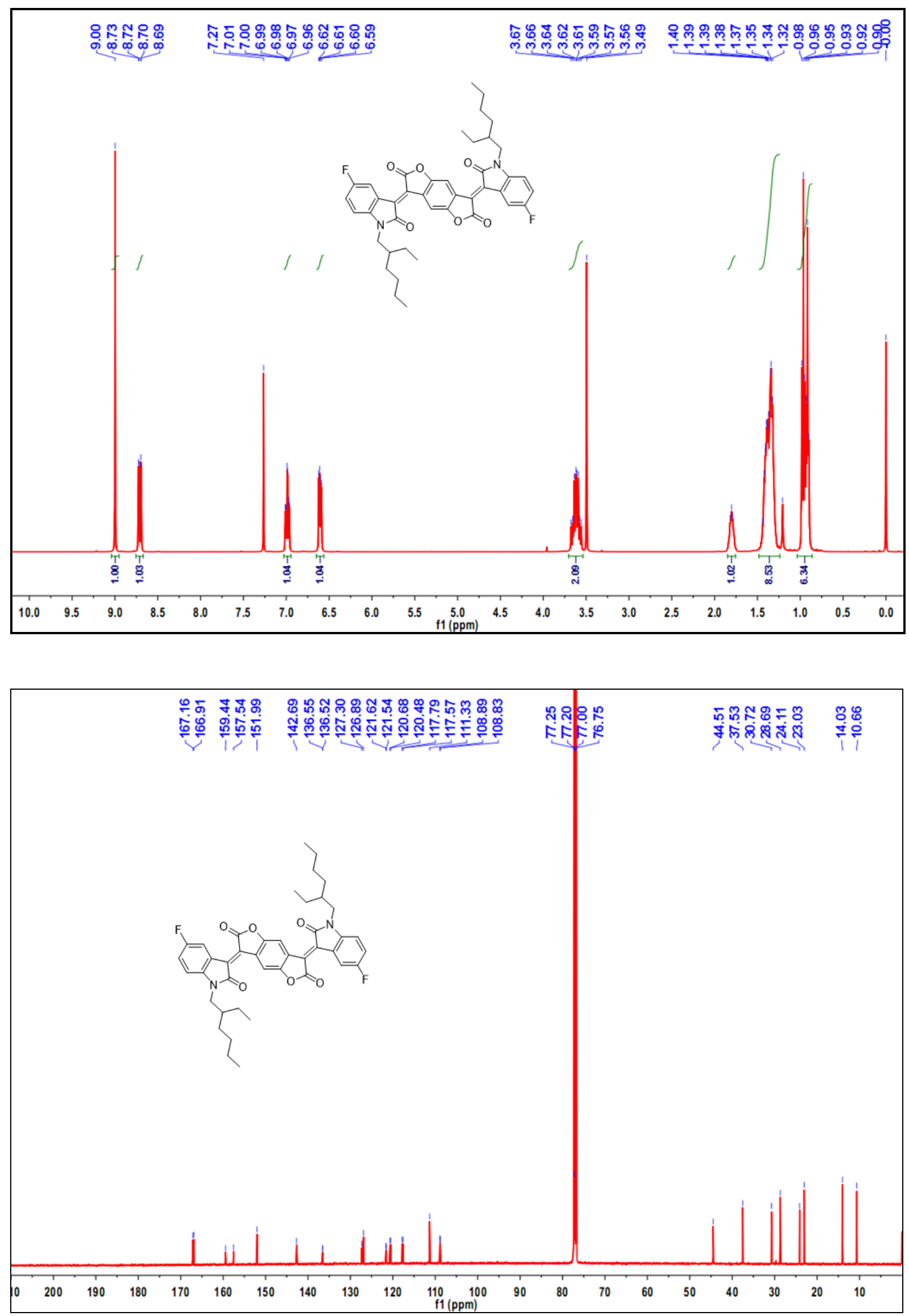

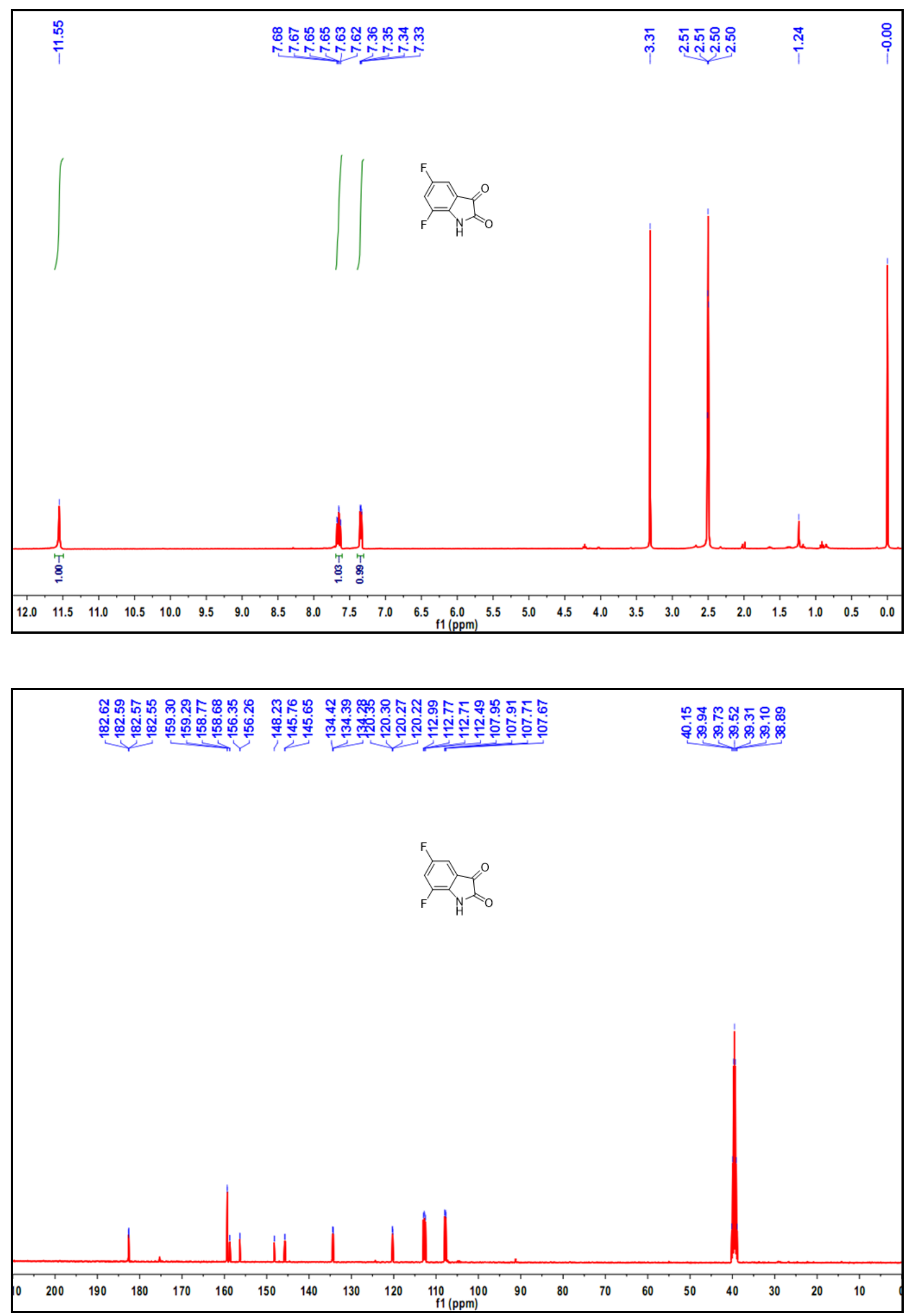

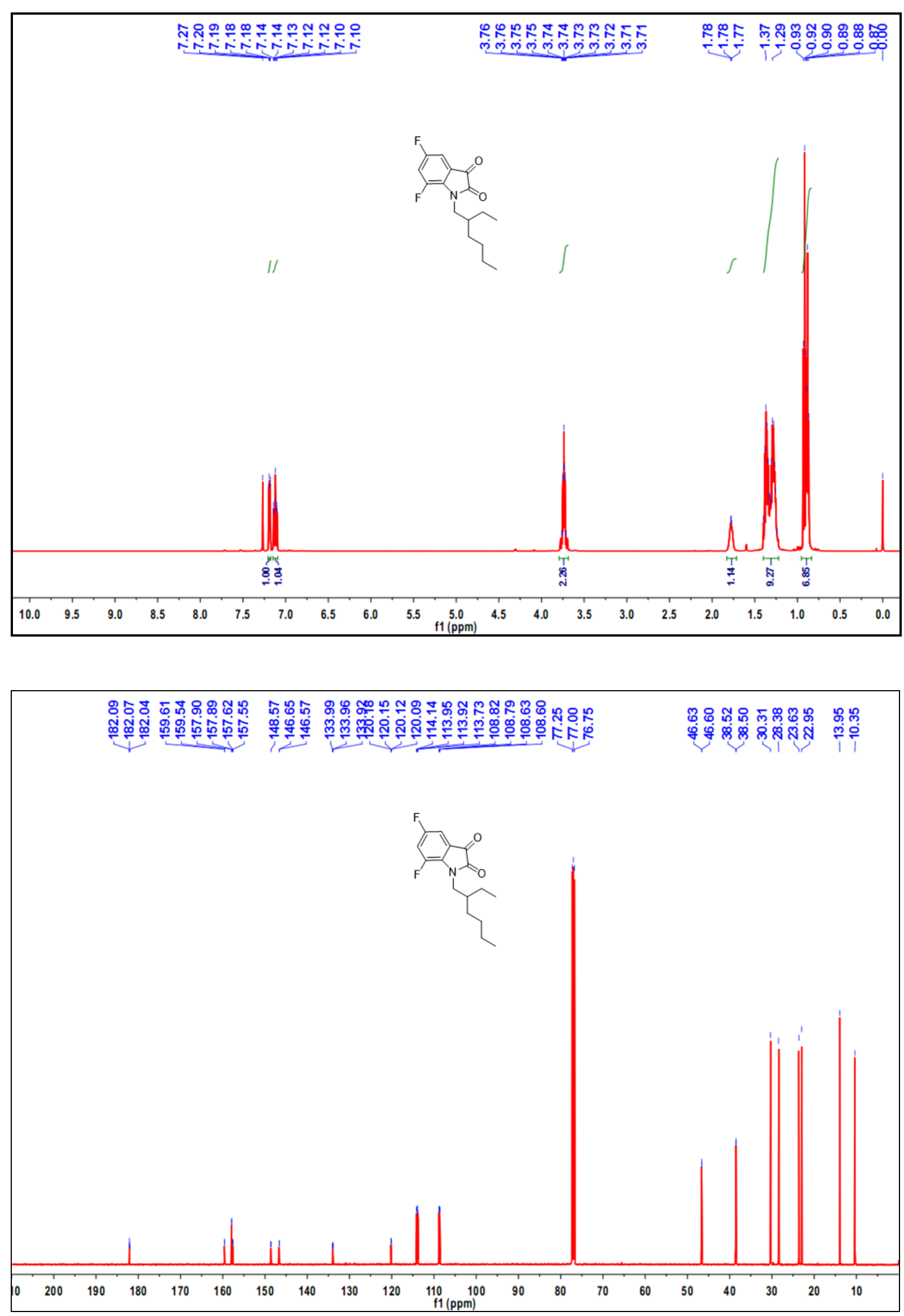

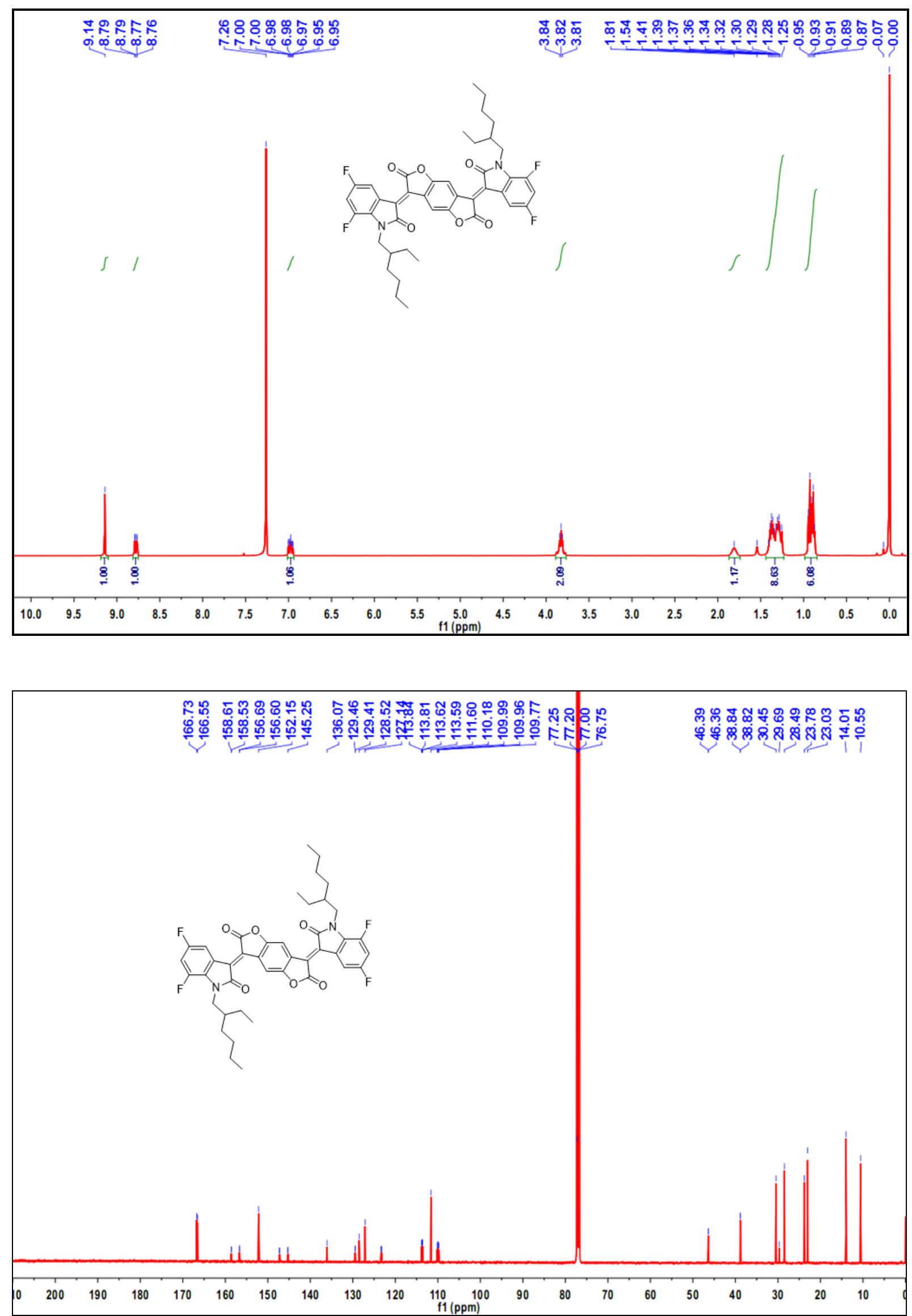


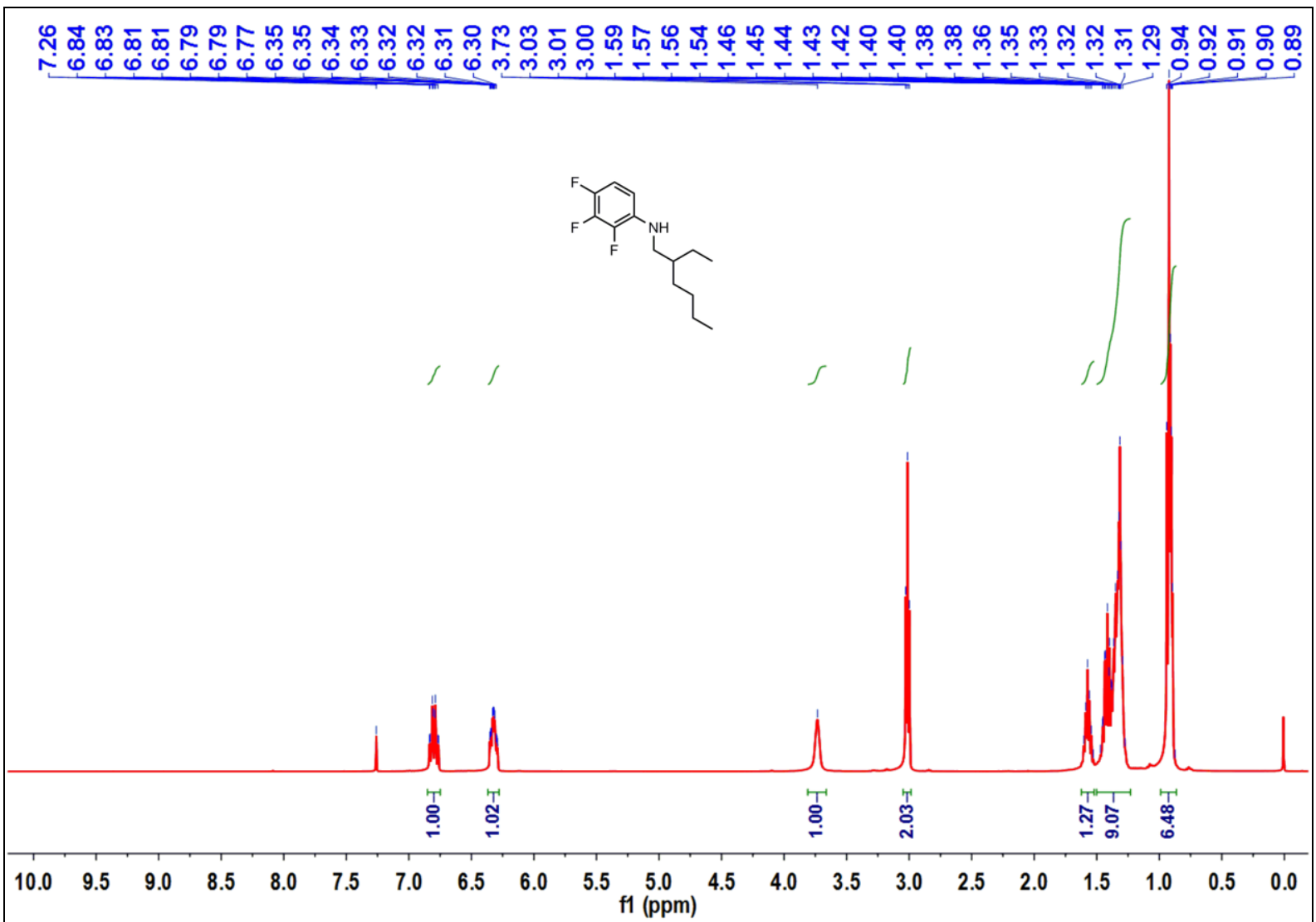

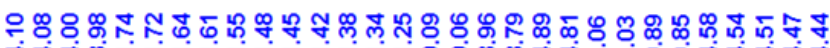

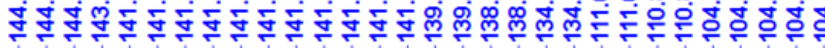

న్లి:

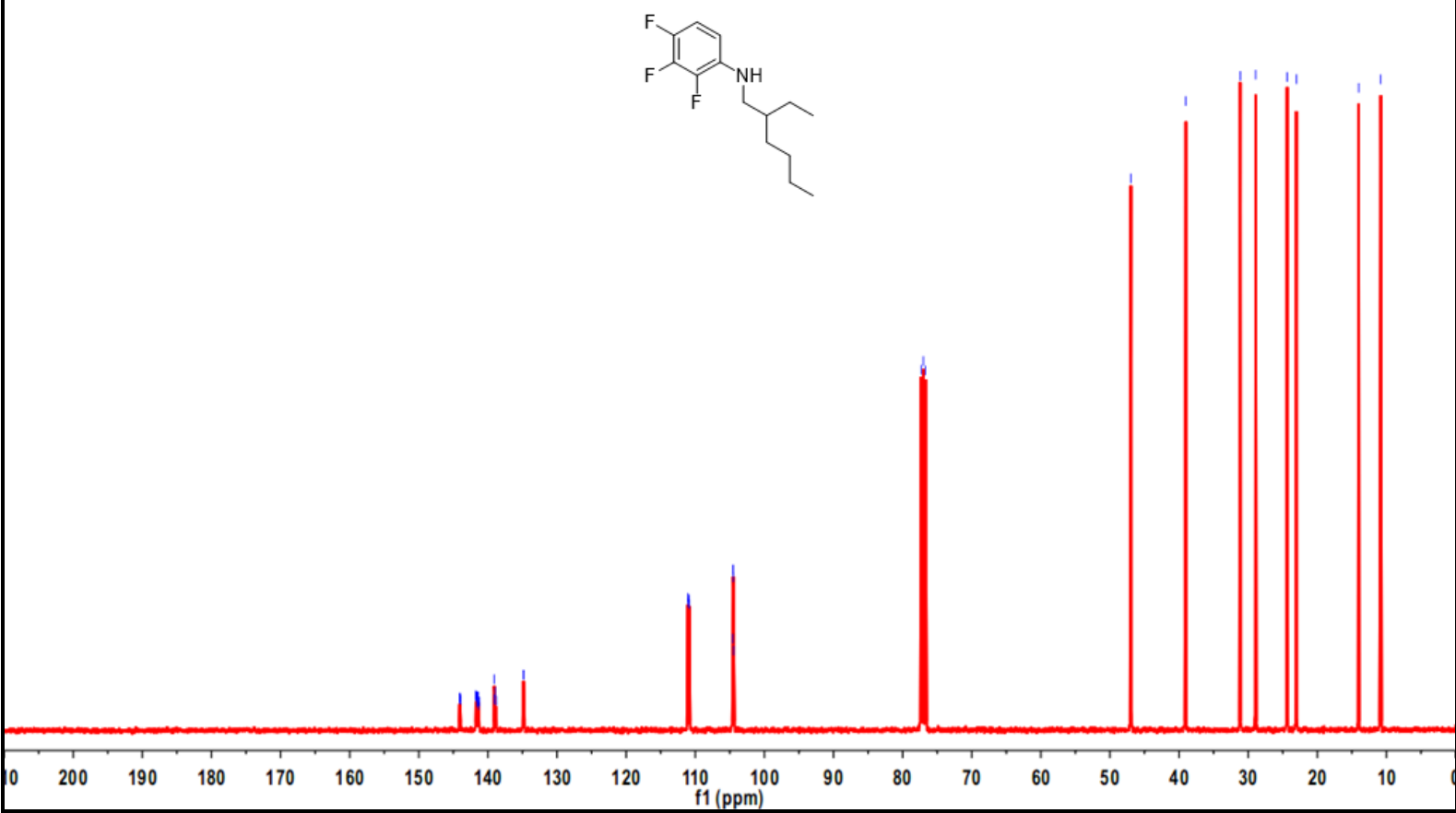



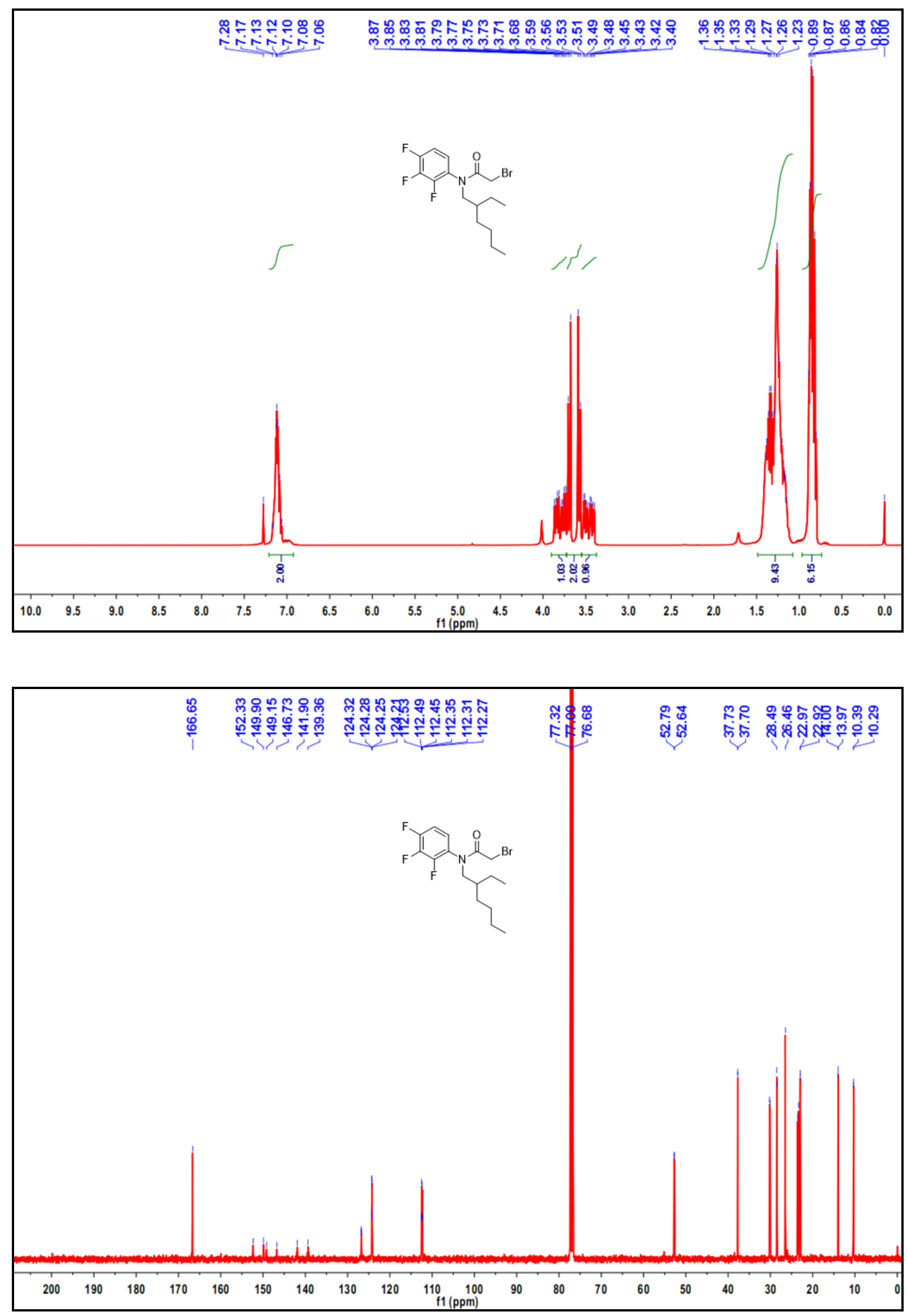


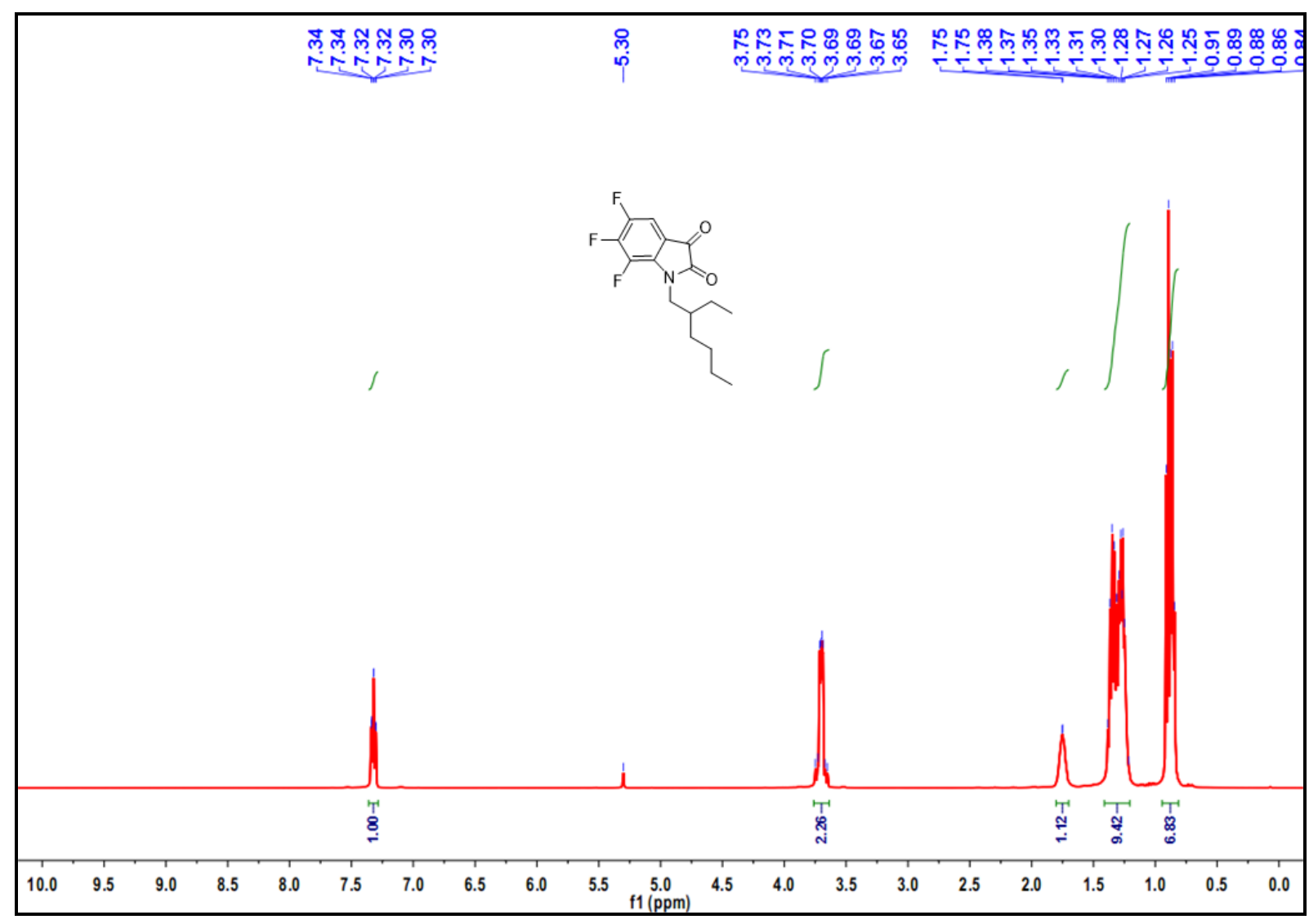

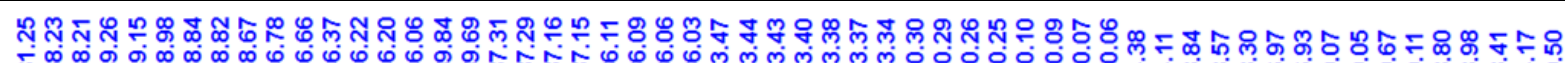

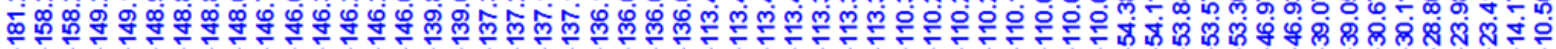

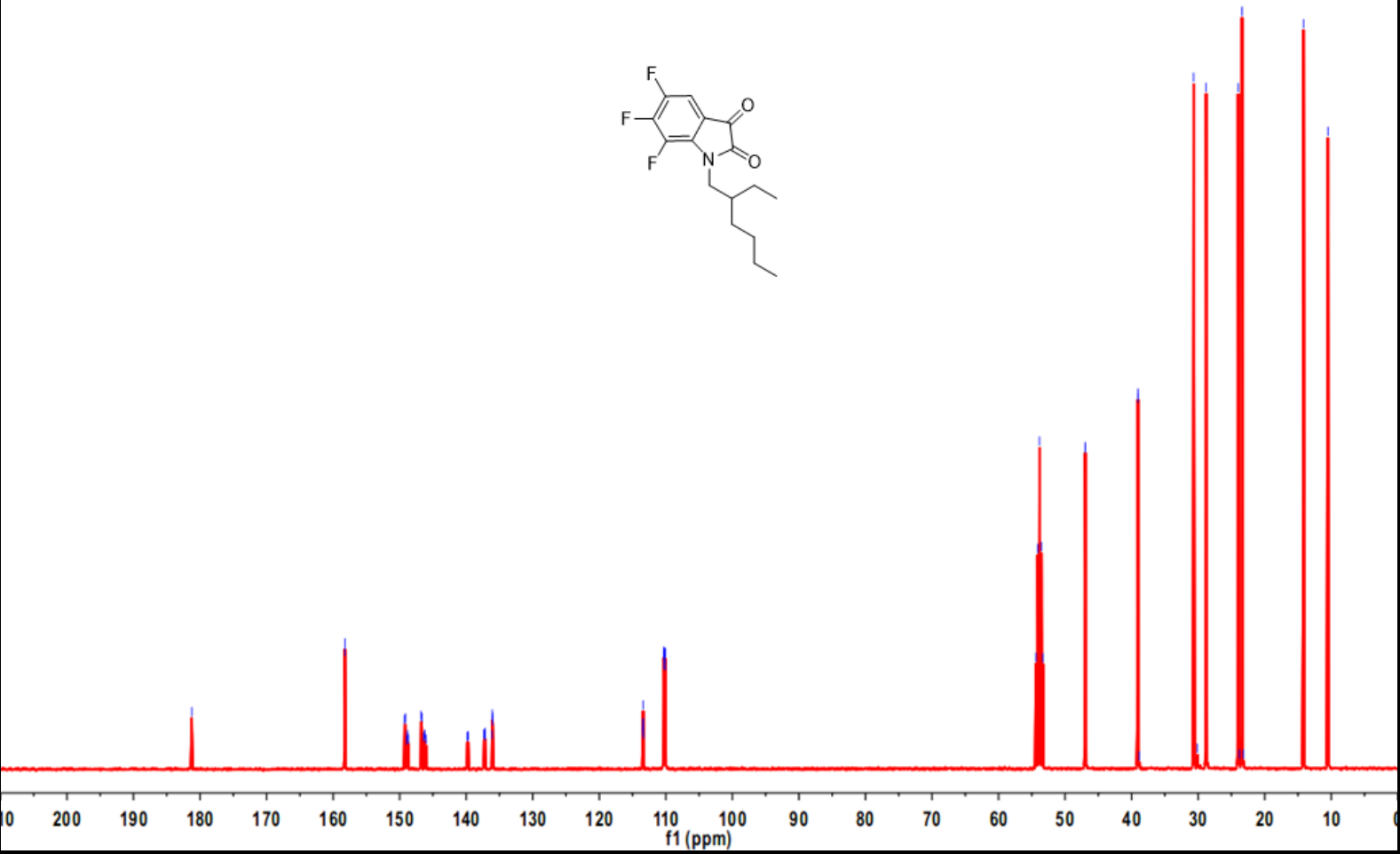



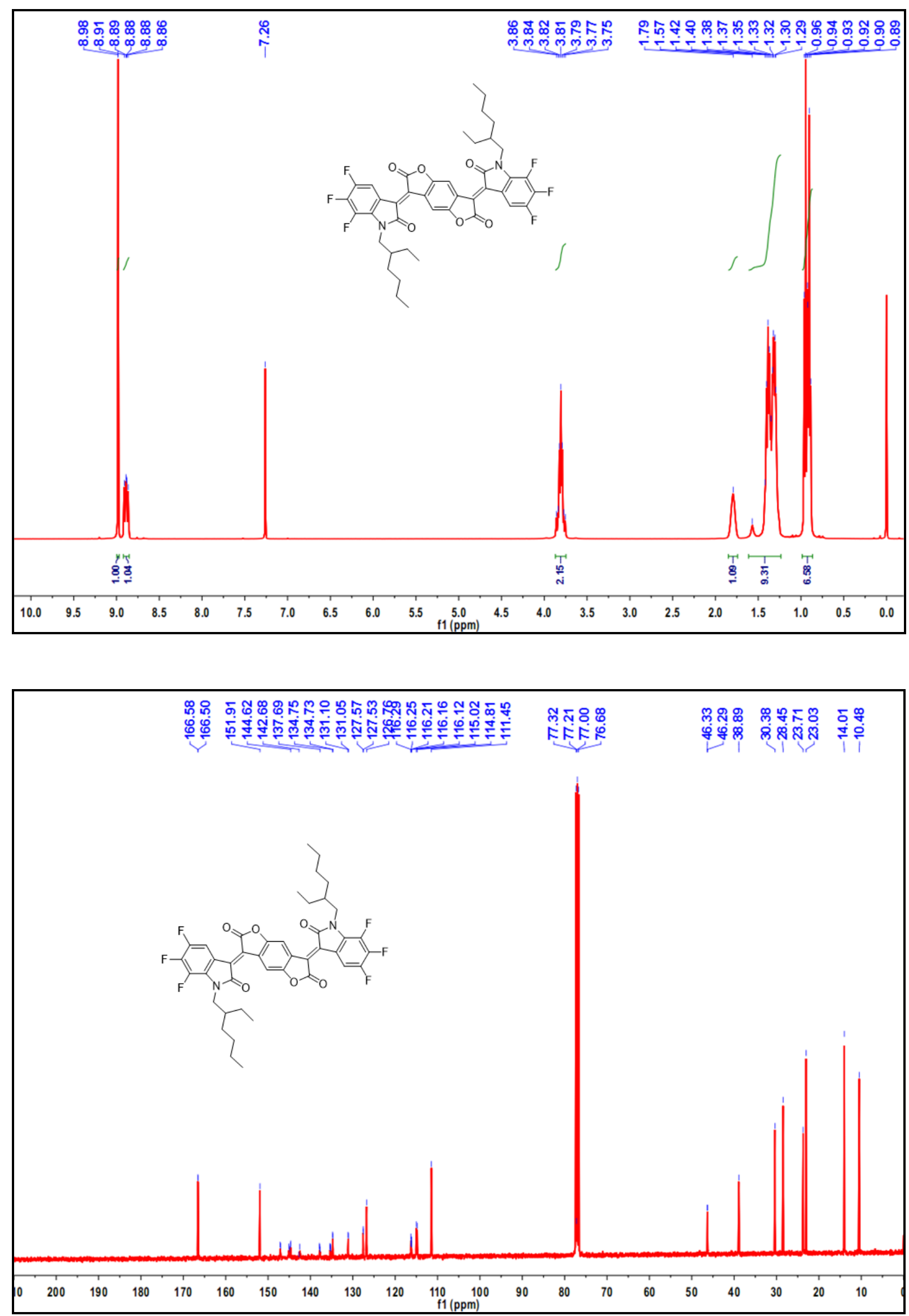